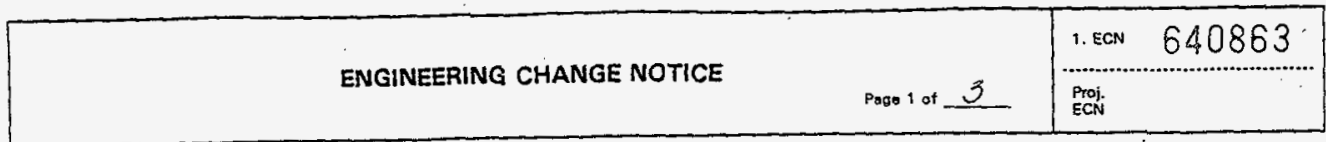

\begin{tabular}{|c|c|c|c|}
\hline \multirow{3}{*}{$\begin{array}{lr}\text { 2. ECN Category } & \\
\text { (mark one) } & \\
\text { Supplemental } & {[]} \\
\text { Direct Revision } & {[\mathrm{X}]} \\
\text { Change ECN } & {[]} \\
\text { Temporary } & {[]} \\
\text { Standby } & {[]} \\
\text { Suppersedure } & {[]} \\
\text { Cancel/Void } & {[]}\end{array}$} & $\begin{array}{l}\text { 3. Originator's Name, Organization, MSIN, } \\
\text { and Telephone No. } \\
\text { RJ Smith/03EOO/HI-15/375-9501 }\end{array}$ & $\begin{array}{l}\text { 4. USQ Required? } \\
\text { [] Yes [X] No }\end{array}$ & \multirow{2}{*}{$\begin{array}{l}\text { 5. Date } \\
03 / 25 / 98 \\
\text { 8. Approval Designator } \\
\text { SQ }\end{array}$} \\
\hline & & $\begin{array}{c}\text { 7. Bldg./Sys./Fac. No. } \\
\text { NA }\end{array}$ & \\
\hline & & 10. Related ECN No(s). & \\
\hline \multirow{3}{*}{ 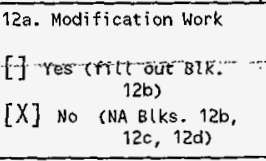 } & \multirow{3}{*}{\multicolumn{2}{|c|}{$\begin{array}{l}\text { 12c. Modification Work Complete } \\
\text { NA } \\
\text { Design Authority/Cog. Engineer } \\
\text { Signature \& Date }\end{array}$}} & \multirow{3}{*}{$\begin{array}{l}\text { 12d. Restored to original Condi- } \\
\text { tion (Temp. or Standby ECN only) } \\
N A \text {. } \\
\text { Design Authority/Cog. Engineer } \\
\text { Signiature \& Date }\end{array}$} \\
\hline & & & \\
\hline & & & \\
\hline \multicolumn{4}{|c|}{$\begin{array}{l}\text { 13a, Description of change................. } \\
\text { This ECN provides new evaluations to support an increase in the fissile loading to } \\
100 \mathrm{~g} \text {. Revised operational controls are provided as a result of the new evaluations. } \\
\text { This ECN al so updates references, contractors, and drawings and provides editorial } \\
\text { clarifications. Specific changes include: } \\
\text { PART A } \\
\text { Section } 1.1: \text { Revise packaging and shipping manual to new reference HNF-PRO-154. } \\
\text { Clarify Jocation of shipment destination (editorial). }\end{array}$} \\
\hline \multicolumn{4}{|c|}{ 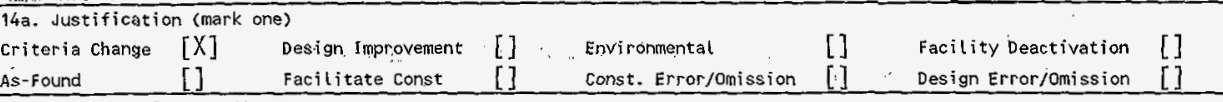 } \\
\hline \multicolumn{4}{|c|}{$\begin{array}{l}\text { 14b. Justification oetails } \\
\text { An increase in the } 327 \text { facility's anticipated fissile payload quantities necessitated a } \\
\text { revision in the SEP's contents, risk, dose consequence, shielding, and criticality } \\
\text { evaluations. New operating limits are imposed as a result of the new evaluations. Due } \\
\text { to the Hanford Site contractor change, appropriate updates are provided to the } \\
\text { references. New drawings are provided, which were revised to include previous drawing } \\
\text { ECNs. } \\
\text { Design verification of this change was performed, and the change(s) were found not to } \\
\text { adversely impact the underlying safety bases and parameters of the package. } \\
\text { Verification performed by: }\end{array}$} \\
\hline \multicolumn{4}{|c|}{$\begin{array}{l}\text { 15. Distribution (include name, MSIN, and no. of copies) } \\
\text { See distribution list. }\end{array}$} \\
\hline
\end{tabular}




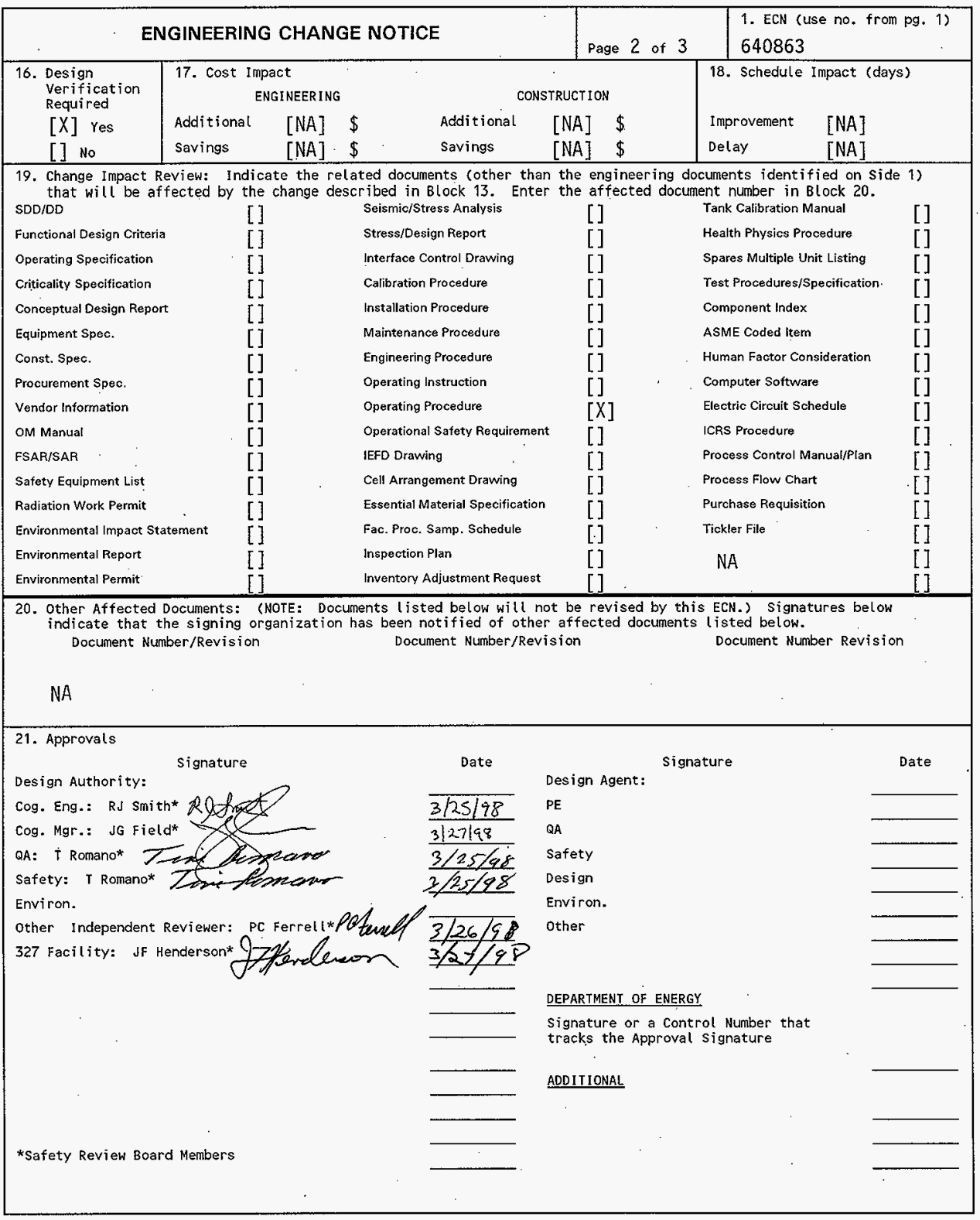


13a. Description of Change (continued)

PART A (continued)

Section 1.2: Remove references to drawing ECNS.

Section 2.3: Remove references to drawing ECNs.

Section 3.1: Include Activated pin tubes as typical contents.

Section 3.2: Revise contents restrictions based on new radiological evaluations.

Section 4.1: Revise drum limits based on new risk evaluation.

Section 4.3: Revise transfer requirements based on new risk and radiological evaluations.

Section 5.1: Remove references to drawing ECNs.

Section 6.1: Revise maximum number of shipments to eight, based on new risk evaluation.

Section 6.2: Revise loading limits based on new risk and radiological evaluations.

Section 7.1: Revise $Q A$ requirements to new contractor references.

Section 9.0: Revise to new contractor references.

Section 10.0: Provide new (Rev. 1) drawings.

PART B

Section 1.1: Remove references to PNNL.

Section 1.2: Revise requirements based on new risk and radiological evaluations.

Section 2.0: Complete revision of contents evaluation due to increase in fissile quantity from $15 \mathrm{~g}$ to $100 \mathrm{~g}$.

Section 3.0: Complete revision of risk evaluation due to increased dose consequence of revised contents.

Section 4.6: Revise dose consequence evaluation due to revised contents.

Section 5.0: Complete revision of shielding evaluation due to revised contents.

Section 6.0: Complete revision of criticality evaluation due to increased fissile Toad.

Section 7.0: Minor editorial revision reflecting contractor change.

Section 8.0: Clarify location of shipment destination (editorial). 


\section{Safety Evaluation for Packaging (Onsite) for the Concrete-Shielded RH TRU Drum for the 327 Postirradiation Testing Laboratory}

R. J. Smith

Waste Management Federal Services, Inc., Northwest Operations

for Fluor Daniel Hanford, Inc., Richland, WA 99352

U.S. Department of Energy Contract DE-AC06-96RL13200

EDT/ECN: $\quad$ ECN 640863

Org Code: $03 E 00$

B\&R Code: EW7050000
UC: 513

Charge Code: P.0. KA41098, Line 82, HAN98200

Total Pages: iona 110

Key Words: transport, Type B quantities, TRUSAF, 327 Building, legacy waste, solid waste storage facility

Abstract: This safety evaluation for packaging authorizes onsite transport of Type $B$ quantities of radioactive material in the concreteShielded Remote-Handled Transuranic Waste (RH TRU) Drum per HNF-PR0-154, Responsibilities and Procedures for all Hazardous Material Shipments. The drum will be used for transport of 327 Building legacy waste from the 300 Area to a solid waste storage facility on the Hanford Site.

TRADEMARK DISCLAIMER. Reference herein to any specific commercial product, process, or service by trade name, trademark, manufacturer, or otherwise, does not necessarily constitute or imply its endorsement, recommendation, or favoring by the United States Government or any agency thereof or

its contractors or subcontractors.

Printed in the United States of America. To obtain copies of this document, contact: WHC/BCS

Document Control Services, P.0. Box 1970, Mailstop H6-08, Richland WA 99352, Phone (509) 372-2420; Fax (509) 376-4989.
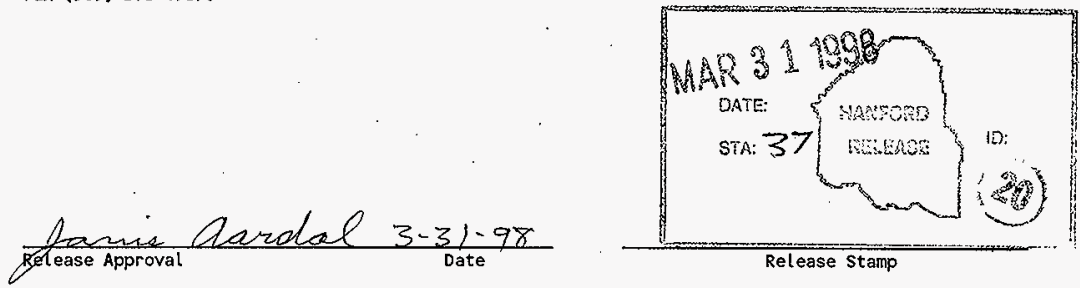


\section{RECORD OF. REVISION}

(1) Docunent Number

HNF-SD-TP-SEP-051

(2) Title

Safety Evaluation for Packaging (Onsite) for the Concrete-Shielded RH TRU Drum for the Postirradiation Testing Laboratory

CHANGE CONTROL RECORD

(3) Revision (4) Description of Change - Replace, Add, and Delete Pages (7) EDT 618181 dated October 29, 1996.

1 RS Provide new evaluations to support an increase in the fissile loading to $100 \mathrm{~g}$. Revised operational controls are provided as a result of the new evaluations. Also update references, contractors, and drawings and provide editorial

clarifications. Replace all pages. Per ECN 640863.

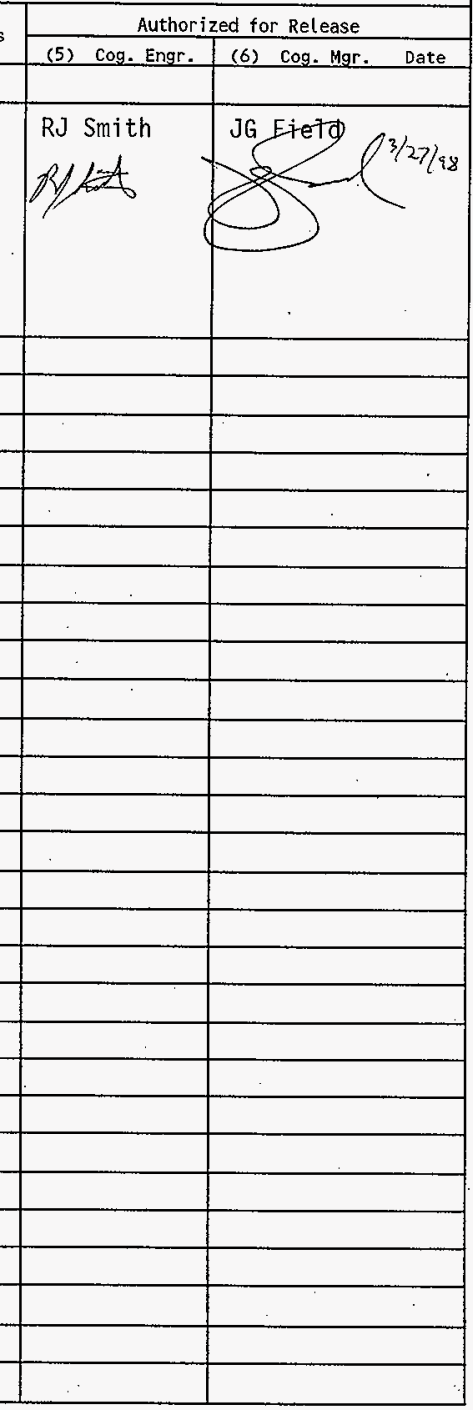




\section{PART A: DESCRIPTION AND OPERATIONS}

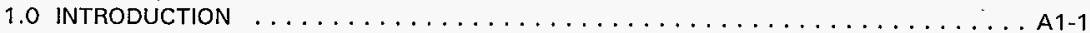

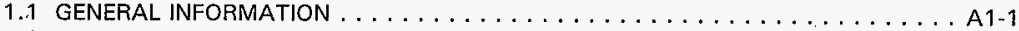

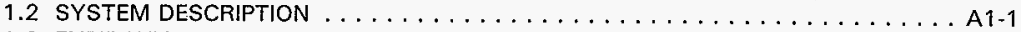

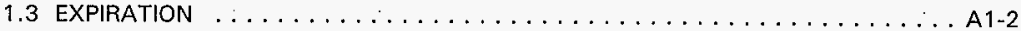

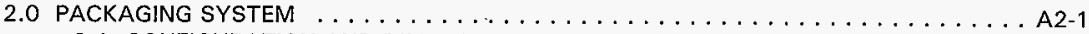

2.1 CONFIGURATION AND DIMENSIONS $\ldots \ldots \ldots \ldots \ldots \ldots \ldots \ldots \ldots \ldots \ldots$ A2-1

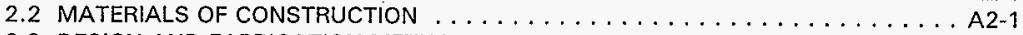

2.3 DESIGN AND FABRICATION METHODS $\ldots \ldots \ldots \ldots \ldots \ldots \ldots \ldots \ldots \ldots \ldots \ldots$ A2-1

2.4 WEIGHTS AND CENTER OF GRAVITY $\ldots \ldots \ldots \ldots \ldots \ldots \ldots \ldots \ldots \ldots \ldots \ldots \ldots \ldots$

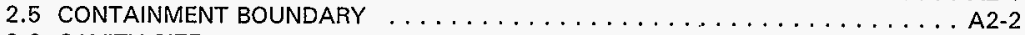

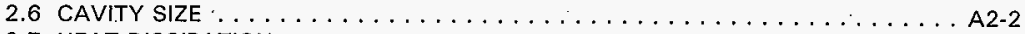

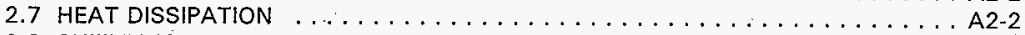

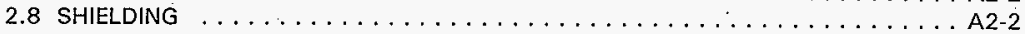

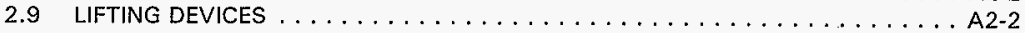

2.10 TIEDOWN DEVICES . . . . . . . . . . . . . . . . . A2-3

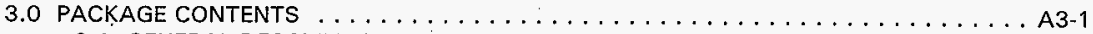

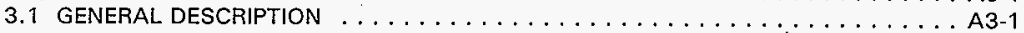

3.2 CONTENTS RESTRICTIONS $\ldots \ldots \ldots \ldots \ldots \ldots \ldots \ldots \ldots \ldots \ldots \ldots \ldots \ldots \ldots \ldots$

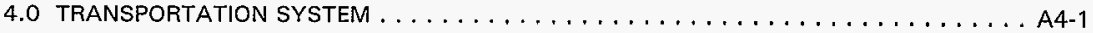

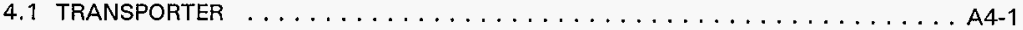

4.2 TIEDOWN SYSTEM AND CARGO CONFIGURATION $\ldots \ldots \ldots \ldots \ldots \ldots \ldots$ A4-1

4.3 SPECIAL TRANSFER REQUIREMENTS $\ldots \ldots \ldots \ldots \ldots \ldots \ldots \ldots \ldots \ldots \ldots \ldots \ldots$

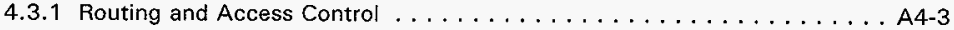

4.3.2 Radiological Limitations . . . . . . . . . . . . . . . A4-3

4.3 .3 Speed Limitations . . . . . . . . . . . . . . . . . A4-3

4.3 .4 Environmental Conditions . . . . . . . . . . . . . . . . A4-4

4.3 .5 Frequency of Use and Mileage Limitations $\ldots \ldots \ldots \ldots \ldots \ldots \ldots$ A4-4

5.0 ACCEPTANCE OF PACKAGING FOR USE $\ldots \ldots \ldots \ldots \ldots \ldots \ldots \ldots \ldots \ldots$. . . . . . . . . $\ldots \ldots$

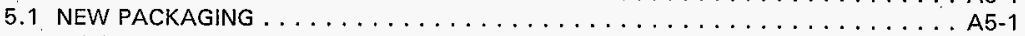

5.1 .1 Acceptance Requirements . . . . . . . . . . . . . . . A5-1

5.1 .2 Inspection and Testing . . . . . . . . . . . . . . . . . A $5-1$

5.2 PACKAGING FOR REUSE $\ldots \ldots \ldots \ldots \ldots \ldots \ldots \ldots \ldots \ldots \ldots \ldots \ldots$ A5-1

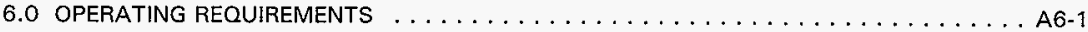

6.1 GENERAL REQUIREMENTS . . . . . . . . . . . . . . . . . . A6-1

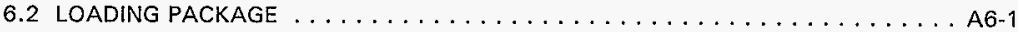

6.3 TRUCK LOADING AND TRANSPORTING $\ldots \ldots \ldots \ldots \ldots \ldots \ldots \ldots \ldots \ldots$ A6-3

6.4 UNLOADING PACKAGE $\ldots \ldots \ldots \ldots \ldots \ldots \ldots \ldots \ldots \ldots \ldots \ldots \ldots \ldots$

7.0 OUALITY ASSURANCE REQUIREMENTS $\ldots \ldots \ldots \ldots \ldots \ldots \ldots \ldots \ldots \ldots \ldots \ldots$ A7-1

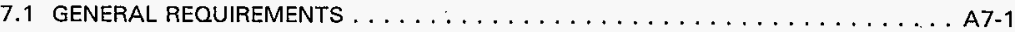

7.2 SEP CONTROL SYSTEM $\ldots \ldots \ldots \ldots \ldots \ldots \ldots \ldots \ldots \ldots \ldots \ldots \ldots \ldots$ A7-1 


\section{CONTENTS (cont.)}

8.0 MAINTENANCE $\ldots \ldots \ldots \ldots \ldots \ldots \ldots \ldots \ldots \ldots \ldots \ldots \ldots \ldots$

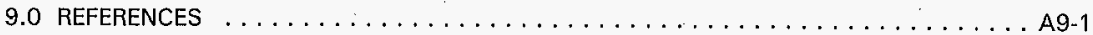

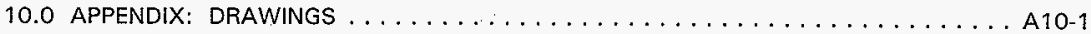

PART B: PACKAGE EVALUATION

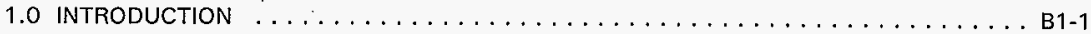

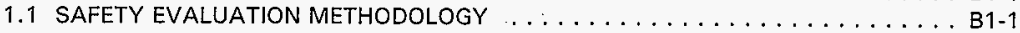

1.2 EVALUATION SUMMARY AND CONCLUSIONS $\ldots \ldots \ldots \ldots \ldots \ldots \ldots$ B1-1

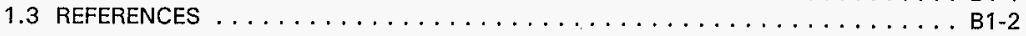

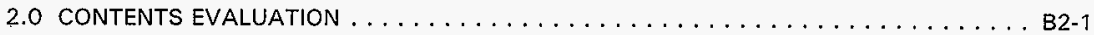

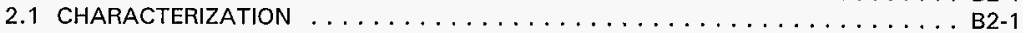

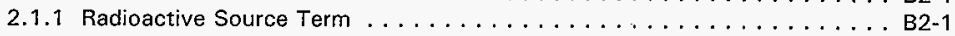

2.1 .2 Chemical Source Term . . . . . . . . . . . . . . . . B $2-1$

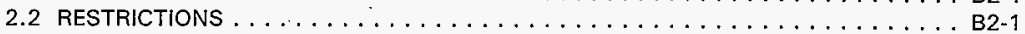

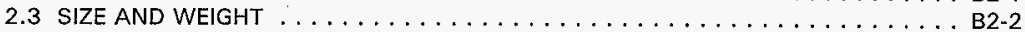

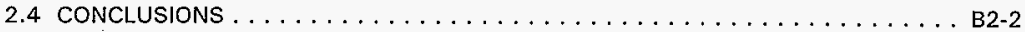

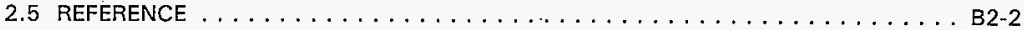

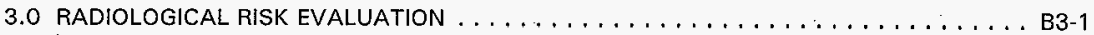

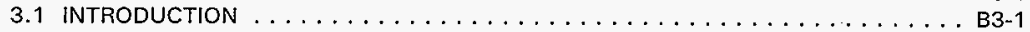

3.1.1 Discussion and Results $\ldots \ldots \ldots \ldots \ldots \ldots \ldots \ldots \ldots \ldots$ B3-1

3.2 RISK ACCEPTANCE CRITERIA $\ldots \ldots \ldots \ldots \ldots \ldots \ldots \ldots \ldots \ldots \ldots \ldots \ldots$ B $\ldots \ldots \ldots$

3.3 DOSE CONSEQUENCE ANALYSIS RESULTS $\ldots \ldots \ldots \ldots \ldots \ldots \ldots \ldots \ldots \ldots \ldots$

3.4 PACKAGE FAILURE THRESHOLD ANALYSIS $\ldots \ldots \ldots \ldots \ldots \ldots \ldots \ldots \ldots \ldots \ldots . . \ldots \ldots$

3.5 ACCIDENT FREQUENCY ASSESSMENT $\ldots \ldots \ldots \ldots \ldots \ldots \ldots \ldots \ldots \ldots \ldots \ldots \ldots$

3.5 .1 Approach . . . . . . . . . . . . . . . . . . . . B3-2

3.5.2 Accident Release Frequency Analysis . . . . . . . . . . . . B3-5

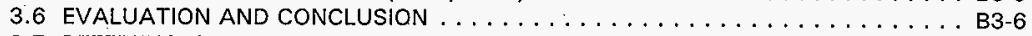

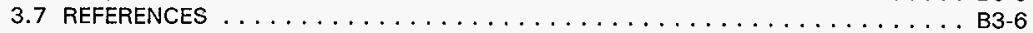

3.8 APPENDIX: PEER REVIEW CHECKLIST $\ldots \ldots \ldots \ldots \ldots \ldots \ldots \ldots \ldots \ldots \ldots$. $\ldots \ldots$.

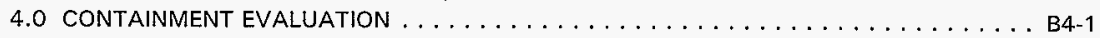

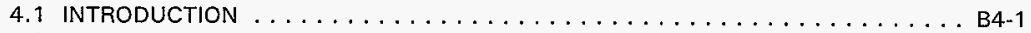

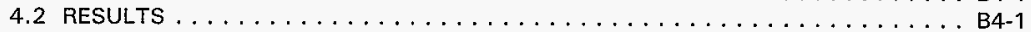

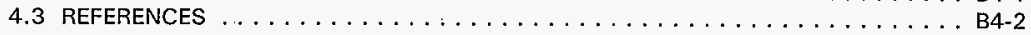

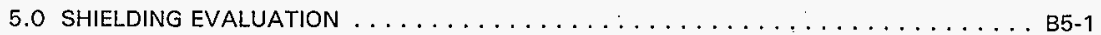

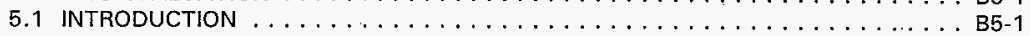

5.2 DIRECT RADIATION SOURCE SPECIFICATION $\ldots \ldots \ldots \ldots \ldots \ldots \ldots \ldots \ldots . \ldots \ldots$

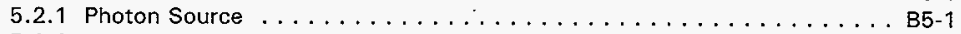

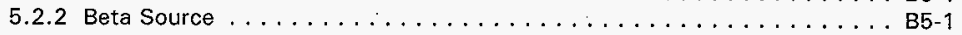

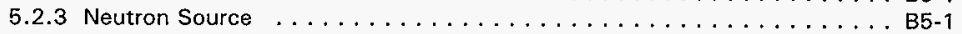

5.3 SUMMARY OF SHIELDING PROPERTIES OF MATERIALS $\ldots \ldots \ldots \ldots \ldots \ldots \ldots$ B5-2 
HNF-SD-TP-SEP-051 ReV. 1

\section{CONTENTS (cont.)}

5.4 NORMAL TRANSFER CONDITIONS $\ldots \ldots \ldots \ldots \ldots \ldots \ldots \ldots \ldots \ldots$

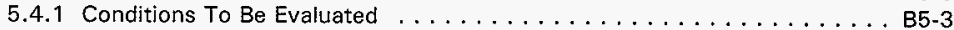

5.4 .2 Acceptance Criteria . . . . . . . . . . . . . . . . . . . B5-3

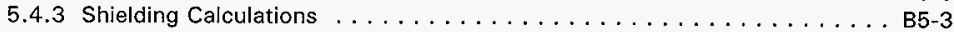

5.5 ACCIDENT CONDITIONS $\ldots \ldots \ldots \ldots \ldots \ldots \ldots \ldots \ldots \ldots \ldots \ldots \ldots \ldots$

5.6 SHIELDING EVALUATION AND CONCLUSIONS $\ldots \ldots \ldots \ldots \ldots \ldots \ldots \ldots \ldots . \ldots \ldots$

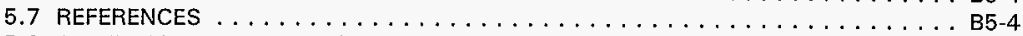

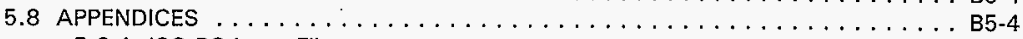

5.8 .1 ISO-PC input File $\ldots \ldots \ldots \ldots \ldots \ldots \ldots \ldots \ldots \ldots \ldots$ B5-4

5.8 .2 Source Term Ratio Documentation . . . . . . . . . . . . B5-6

5.8 .3 Peer Review Checklist . . . . . . . . . . . . . . . . . B5-8

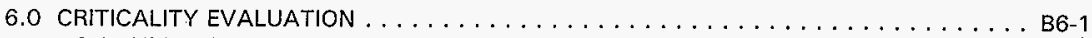

6.1 REFERENCES $\ldots \ldots \ldots \ldots \ldots \ldots \ldots \ldots \ldots \ldots \ldots \ldots \ldots \ldots \ldots \ldots$

7.0 STRUCTURAL EVALUATION $\ldots \ldots \ldots \ldots \ldots \ldots \ldots \ldots \ldots \ldots \ldots \ldots \ldots \ldots \ldots$. $\ldots \ldots \ldots$

7.1 STRUCTURAL DESIGN AND FEATURES $\ldots \ldots \ldots \ldots \ldots \ldots \ldots \ldots \ldots \ldots \ldots$. $\ldots \ldots$. $\ldots \ldots \ldots$

7.2 CHEMICAL AND GALVANIC REACTIONS $\ldots \ldots \ldots \ldots \ldots \ldots \ldots \ldots \ldots \ldots$. $\ldots \ldots$.

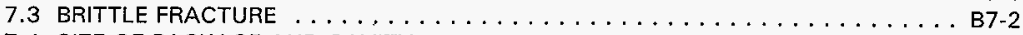

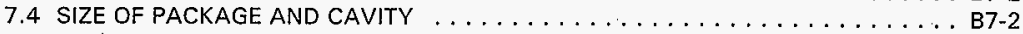

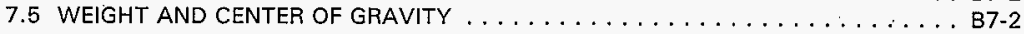

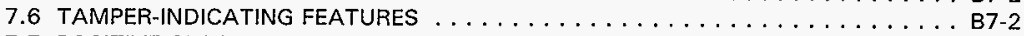

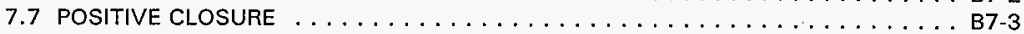

7.8 LIFTING AND TIEDOWN DEVICES $\ldots \ldots \ldots \ldots \ldots \ldots \ldots \ldots \ldots \ldots \ldots$

7.9 NORMAL CONDITIONS OF TRANSPORT (NCT) $\ldots \ldots \ldots \ldots \ldots \ldots \ldots \ldots \ldots$

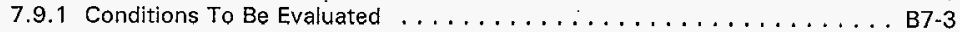

7.9 .2 Acceptance Criteria . . . . . . . . . . . . . . . . . . B B

7.9 .3 Structural Model . . . . . . . . . . . . . . . . . . . B7-3

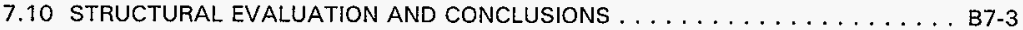

7.11 ACCIDENT FAILURE THRESHOLDS $\ldots \ldots \ldots \ldots \ldots \ldots \ldots \ldots \ldots$. . . . . . .

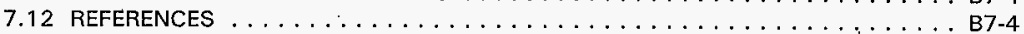

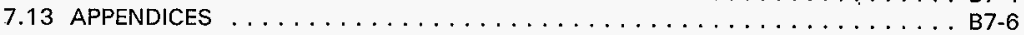

7.13.1 Engineering Safety Evaluation--Failure Thresholds . . . . . . . . . B B 6

7.13 .2 Engineering Safety Evaluation--NCT Drop . . . . . . . . . . . B7-17

8.0 THERMAL EVALUATION $\ldots \ldots \ldots \ldots \ldots \ldots \ldots \ldots \ldots \ldots \ldots \ldots \ldots$. . . . . . . . . . . . . .

8.1 SUMMARY OF THERMAL PROPERTIES OF MATERIALS $\ldots \ldots \ldots \ldots \ldots \ldots \ldots$ B8-1

8.2 THERMAL EVALUATION FOR NCT $\ldots \ldots \ldots \ldots \ldots \ldots \ldots \ldots \ldots \ldots \ldots$ B8-1

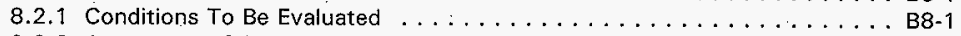

8.2 .2 Acceptance Criteria . . . . . . . . . . . . . . . . . . B8-1

8.2.3 Thermal Model $\ldots \ldots \ldots \ldots \ldots \ldots \ldots \ldots \ldots \ldots \ldots$ B8-2

8.3 THERMAL EVALUATION AND CONCLUSIONS $\ldots \ldots \ldots \ldots \ldots \ldots \ldots \ldots$. . . $\ldots \ldots$

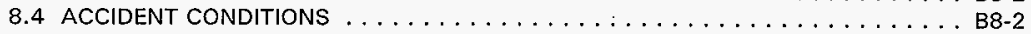

8.5 REFERENCES $\ldots \ldots \ldots \ldots \ldots \ldots \ldots \ldots \ldots \ldots \ldots \ldots \ldots \ldots \ldots$. . . . . . . .

8.6 APPENDIX: ENGINEERING SAFETY EVALUATION--TEMPERATURES $\ldots \ldots \ldots \ldots$. . . B8-3

9.0 PRESSURE AND GAS GENERATION EVALUATION $\ldots \ldots \ldots \ldots \ldots \ldots \ldots \ldots$. . . . . . 
HNF-SD-TP-SEP-051 Rev. 1

CONTENTS (cont.)

10.0 PACKAgE TIEDOWN SYSTEM EVALUATION $\ldots \ldots \ldots \ldots \ldots \ldots \ldots \ldots \ldots \ldots$ B10-1

10.1 SYSTEM DESIGN $\ldots \ldots \ldots \ldots \ldots \ldots \ldots \ldots \ldots \ldots \ldots \ldots \ldots \ldots$ B $\ldots \ldots \ldots$

10.2 ATTACHMENTS AND RATINGS $\ldots \ldots \ldots \ldots \ldots \ldots \ldots \ldots \ldots \ldots \ldots$ B10-1

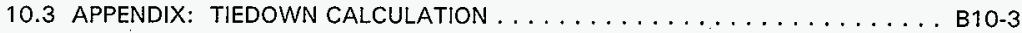

\section{LIST OF FIGURES}

A4-1 Truck Loading Arrangement and Details $\ldots \ldots \ldots \ldots \ldots \ldots \ldots \ldots \ldots$. . . . . . . .

B3-1 Flow Chart for Small Package Accidents. . . . . . . . . . . . . . . . B3-4

B10-1 Truck Loading Arrangement and Details $\ldots \ldots \ldots \ldots \ldots \ldots \ldots \ldots \ldots$ B10-2

\section{LIST OF TABLES}

A4-1 External Container Contamination Limits $\ldots \ldots \ldots \ldots \ldots \ldots \ldots \ldots \ldots \ldots$. . . . . A4-4

B3-1 Risk Acceptance Criteria Limits (Effective Dose Equivalent) $\ldots \ldots \ldots \ldots \ldots \ldots$. . . . . .

B3-2 Failure Thresholds, Occurrence, and Conditional Failure Probabilities . . . . . . . B3-5

B5-1 Source Term for One Drum $\ldots \ldots \ldots \ldots \ldots \ldots \ldots \ldots \ldots \ldots \ldots \ldots \ldots \ldots \ldots$

B7-1 Structural Materials of Construction at $93.3^{\circ} \mathrm{C}\left(200^{\circ} \mathrm{F}\right) \ldots \ldots \ldots \ldots \ldots \ldots$

B8-1 Summary of Thermal Properties $\ldots \ldots \ldots \ldots \ldots \ldots \ldots \ldots \ldots \ldots \ldots \ldots$ B8-1 


\section{LIST OF TERMS}

\begin{tabular}{|c|c|}
\hline ARF & airborne release fraction \\
\hline ASTM & American Society for Testing and Materials \\
\hline $\mathrm{Bq}$ & becquerel \\
\hline Btu/h-ft- ${ }^{\circ} \mathrm{F}$ & British thermal units per hour-foot degree Fahrenheit \\
\hline $\mathrm{Ci}$ & curie \\
\hline $\mathrm{cm}$ & centimeter \\
\hline $\mathrm{dpm} / \mathrm{cm}^{2}$ & disintegrations per minute per square centimeter \\
\hline EDE & effective dose equivalent \\
\hline ECN & engineering change notice \\
\hline $\mathrm{HRCQ}$ & highway route controlled quantity \\
\hline IAEA & International Atomic Energy Agency \\
\hline ID & inside diameter \\
\hline & inch \\
\hline $\mathrm{ft}$ & foot \\
\hline ft-lb & foot-pound \\
\hline $\mathrm{g} \quad$ & gram \\
\hline $\mathrm{g} / \mathrm{cm}^{3}$ & grams per cubic centimeter \\
\hline $\mathrm{g} / \mathrm{cm}^{2}$ & grams per square centimeter \\
\hline gal & gallon \\
\hline $\mathrm{J} / \mathrm{kg}-\mathrm{K}$ & joules per kilogram kelvin \\
\hline $\mathrm{kg}$ & kilogram \\
\hline $\mathrm{kg} / \mathrm{m}^{3}$ & kilograms per cubic meter \\
\hline $\mathrm{km}$ & kilometer \\
\hline $\mathrm{km} / \mathrm{h}$ & kilometers per hour \\
\hline ksi & 1000-lb per square inch \\
\hline lb & pound \\
\hline $\mathrm{lb} / \mathrm{ft}^{3}$ & pounds per cubic foot \\
\hline $\mathrm{m}$ & meter \\
\hline $\mathrm{MeV}$ & megaelectronvolt \\
\hline$\mu \mathrm{Ci} / \mathrm{cm}^{2}$ & microcuries per square centimeter \\
\hline $\mathrm{mi}$ & mile \\
\hline $\mathrm{MPa}$ & megapascal \\
\hline $\mathrm{mph}$ & miles per hour \\
\hline $\mathrm{mrem} / \mathrm{h}$ & millirem per hour \\
\hline $\mathrm{mSv} / \mathrm{h}$ & millisievert per hour \\
\hline NCT & normal conditions of transport \\
\hline Pacific Northwest & Pacific Northwest National Laboratory \\
\hline psi & pounds per square inch \\
\hline psia & pounds per square inch, absolute \\
\hline $\mathrm{rem} / \mathrm{h}$ & rem per hour \\
\hline RH TRU & Remote-Handled Transuranic Waste \\
\hline SARP & safety analysis report for packaging \\
\hline SEP & safety evaluation for packaging \\
\hline$s / m^{3}$ & seconds per cubic meter \\
\hline Sv & sievert \\
\hline $\mathrm{Sv} / \mathrm{h}$ & sievert per hour \\
\hline $\mathrm{TBq}$ & terabecquerel \\
\hline THI & Transportation Hazard Indicator \\
\hline TRU & transuranic (waste) \\
\hline TRUSAF & Transuranic Waste Storage and Assay Facility \\
\hline $\mathrm{W} / \mathrm{m}^{2}-\mathrm{K}$ & watts per square meter kelvin \\
\hline
\end{tabular}


HNF-SD-TP-SEP-051 Rev. 1

This page intentionally left blank. 


\section{SAFETY EVALUATION FOR PACKAGING (ONSITE) FOR THE CONCRETE-SHIELDED RH TRU DRUM FOR THE 327 POSTIRRADIATION TESTING LABORATORY}

\section{PART A: DESCRIPTION OF OPERATIONS}

\subsection{INTRODUCTION}

\subsection{GENERAL. INFORMATION}

This safety evaluation for packaging (SEP) evaluates and documents the ability of the Concrete-Shielded Remote-Handled Transuranic Waste (RH TRU) Drum assembly to meet the packaging requirements of HNF-PRO-154, Responsibilities and Procedures for All Hazardous Material Shipments, for the onsite transfer of Type B quantities of radioactive material. Onsite transfer is the transport of hazardous materials on controlled routes confined to established limited areas and to portions of federally owned roadways to which public access is prohibited during transfer.

This document shall be used by operations to ensure loading, tiedown of the packaging on the transport vehicle, and unloading are performed in agreement with HNF-PRO-154. The analyses documented in this SEP demonstrate compliance of the Concrete-Shielded RH TRU Drum to the onsite transportation safety requirements.

The Concrete-Shielded RH TRU Drum will be used for transport of 327 Building legacy waste (hot cell debris) from the 300 Area to a solid waste storage facility on the Hanford Site. The waste will remain in the drum for an indefinite period of storage at that facility.

This SEP demonstrates, by analysis or by reference to existing safety analysis reports for packaging (SARP), that the Concrete-Shielded RH TRU Waste Drum meets the onsite transportation safety requirements for Type B quantity packaging. Where possible, this SEP minimizes new analyses and draws upon the analyses, constraints, and logic of the Safety Analysis Report for Packaging (Onsite) Internally Shie/ded 55-Gallon Drum (SD-RE-SAP-043).

\subsection{SYSTEM DESCRIPTION}

The packaging consists of a 55-gal UN1A2 galvanized steel drum procured to U.S. Department of Transportation Specification 7A, Type A, and modified per Pacific Northwest National Laboratory (Pacific Northwest) drawing H-3-304541. Modifications include a steel inner cavity with concrete shielding on the sides and steel shielding on the top and bottom. The cavity has a steel shield plug and a gasketed and bolted steel cover. An impact-limiting foam filler is provided between the shield plug and the cover. NucFil ${ }^{1}-013$ filters are installed in the cavity cover and the drum lid to eliminate any possibility for pressure buildup. A removable sheet metal liner ( $\mathrm{H}-3-304558)$ with a lifting bail provides a means of handling the waste containers (paint cans)

\footnotetext{
${ }^{1}$ NucFil is a trademark of NFT Incorporated.
} 


\section{HNF-SD-TP-SEP-051 Rev. 1}

during removal from the hot cell and insertion into the drum. It remains in the drum with the payload.

Tiedown of the package for transport will be accomplished using a modified application of standard techniques as specified in Section 4.2.

\subsection{EXPIRATION}

Use of this SEP is limited to a period of one year from the date of the first shipment. If it becomes desirable to maintain the packaging design for ongoing use, it will be necessary to prepare a SARP. 
HNF-SD-TP-SEP-051 Rev. 1

\subsection{PACKAGING SYSTEM}

\subsection{CONFIGURATION AND DIMENSIONS}

The Concrete-Shielded RH TRU Waste Drum has the external dimensions of a standard UN1A2 55-gal galvanized carbon steel drum. The inner cavity is 8 -in. schedule 40 carbon steel pipe (20.04 cm [7.891-in.] inside diameter [ID] $\times 0.818 \mathrm{~cm}[0.322-\mathrm{in}$.$] wall) with a usable inside$ height of $62.23 \mathrm{~cm}(24.5 \mathrm{in}$.). The removable sheet metal liner has an ID of approximately 117.58 $\mathrm{cm}[6.92 \mathrm{in.}])$. The upper section of the inner cavity is formed by an $8-x-10$-in. schedule 40 concentric reducer fitted with a flange on the exterior of the 10 -in. end. A $6.35-\mathrm{cm}-(2.5-$-in.-) thick steel shield plug fits in the tapered transition of the reducer. A $1.9-\mathrm{cm}-(0.75-\mathrm{in} .-)$ thick steel cover and silicone gasket fit on the upper (10 in.) end of the reducer and is secured to the flange with 12 , $1 / 2$-in.-diameter steel bolts. A polyurethane foam impact limiter is placed between the shield plug and the bolted cover. The bottom end of the cavity is closed and shielded with a $6.35-\mathrm{cm}-(2.5-\mathrm{in}$.) thick steel plate welded to the 8-in. pipe. NucFil filters are installed in both the inner cavity cover plate and the drum lid. Concrete $(20.68 \mathrm{MPa}$ [3000 psi] minimum compressive strength with a density of 2,307 to $2,643 \mathrm{~kg} / \mathrm{m}^{3}$ [144 to $165 \mathrm{lb} / \mathrm{ft}^{3}$ ]) fills the annulus between the sides of the inner cavity and the drum wall to provide radial shielding. The maximum weight of the drum, including contents, shall not exceed $657.7 \mathrm{~kg}(1,450 \mathrm{lb})$.

\subsection{MATERIALS OF CONSTRUCTION}

The inner cavity pipe is American Society for Testing and Materials (ASTM) A106, Grade B, carbon steel. The reducer is ASTM A234, Grade WPB, carbon steel. The cavity flange is ASTM A516 normalized carbon steel, and the cover plate is ASTM A516 carbon steel, normalized and produced to fine grain practice. The bottom plate is ASTM A516, any grade, carbon steel, normalized and produced to fine grain practice.

The gasket is solid silicone rubber ZZ-R-765 Class 2, $70+1-5$ Durometer, or equivalent. The impact limiter is LAST-A-FOAM ${ }^{2}$ FR- 6704 polyurethane foam, $64 \mathrm{~kg} / \mathrm{m}^{3}\left(4 \mathrm{lb} / \mathrm{ft}^{3}\right)$ density.

The basic drum is 18-gage (or heavier) galvanized carbon steel with an 18-gage (or heavier) galvanized carbon steel lid, a standard gasket, and a standard bolted lock ring.

\subsection{DESIGN AND FABRICATION METHODS}

The original design of the Concrete-Shielded RH TRU Waste Drum was performed for Pacific Northwest by ICF Kaiser Hanford Company with structural input from Westinghouse Hanford Company, Packaging Engineering. Fabrication will be performed in accordance with drawing $\mathrm{H}-3-304541$ (drum) and drawing $\mathrm{H}-3-304558$ (removable liner). Materials of construction shall be as identified on the drawings.

\subsection{WEIGHTS AND CENTER OF GRAVITY}

The gross weight of the loaded Concrete-Shielded RH TRU Waste Drum shall not exceed $657.7 \mathrm{~kg}(1,450 \mathrm{lb})$. The maximum tare weight for the empty packaging is calculated as $630.5 \mathrm{~kg}$ $(1,390 . \mathrm{lb})$ when fabricated with concrete of the maximum density specified on the drawing. The

${ }^{2}$ LAST-A-FOAM is a trademark of General Plastics Manufacturing Company. 
maximum estimated payload weight is $13.6 \mathrm{~kg}(30 \mathrm{lb})$ (estimated at up to six paint cans at $2.3 \mathrm{~kg}$ $[5 \mathrm{lb}]$ each). The tare weight of each paint can is estimated at $0.34 \mathrm{~kg}(0.75 \mathrm{lb})$.

The center of gravity for the loaded container is calculated to be $43.7 \mathrm{~cm}(17.2 \mathrm{in}$.) from the bottom end with concrete of $2,403 \mathrm{~kg} / \mathrm{m}^{3}\left(150 \mathrm{lb} / \mathrm{ft}^{3}\right)$. Center-of-gravity variations with concrete of other densities within the specified range are negligible.

\subsection{CONTAINMENT BOUNDARY}

Primary containment in this packaging is provided by the inner cavity structure, which has heavy walls and a substantial bolted cover. The drum provides a secondary containing function as well as structural support and strength to the concrete shielding. NucFil filters in both the inner container cover and the drum lid prevent pressure buildup while preventing radionuclide release.

This packaging provides markedly better containment of the payload than either the Transuranic Radioactive Material in the 55-Gallon Drum, HCS-042-002, Safety Analysis Report for Packaging (Onsite) (SD-RE-SAP-033) or the SD-RE-SAP-043 SARP. Both of these packagings rely on the drum itself for primary containment with additional containment provided by a $0.10-\mathrm{mm}$ (4-mil-) thick polyethylene liner, which is horsetailed and taped for closure.

\subsection{CAVITY SIZE}

The inrier cavity of the Concrete-Shielded RH TRU Waste Drum is $20.27 \mathrm{~cm}$ ( $7.981 \mathrm{in.}$ ) ID by $62.23 \mathrm{~cm}(24.5 \mathrm{in}$.) usable depth. The removable liner reduces the usable diameter to approximately $17.58 \mathrm{~cm}(6.92 \mathrm{in.})$.

\subsection{HEAT DISSIPATION}

Decay heat within the Concrete-Shielded RH TRU Waste Drum is considered negligible because it is expected to be less than $1 \mathrm{~W}$.

\subsection{SHIELDING}

Shielding on the sides of the drum is provided by approximately $17 \mathrm{~cm}(6.7 \mathrm{in.})$ of concrete plus approximately $0.9 \mathrm{~cm}(0.35 \mathrm{in}$.) of steel (pipe wall plus drum wall). The concrete has a compressive strength of $20.68 \mathrm{MPa}(3,000 \mathrm{psi})$ and a density of 2,307 to $2,643 \mathrm{~kg} / \mathrm{m}^{3}(144$ to 165 $\left.\mathrm{lb} / \mathrm{ft}^{3}\right)$. thickness.

Shielding on the bottom is provided by $6.35 \mathrm{~cm}(2.5 \mathrm{in.})$ of steel plus the drum bottom

Top shielding consists of a $6.35-\mathrm{cm}(2.5-\mathrm{in}$.) steel shield plug and a $0.34-\mathrm{cm}$. (0.75-in.) inner cavity cover, plus the drum lid $10.16 \mathrm{~cm}[0.062 \mathrm{in.}])$.

\subsection{LIFTING DEVICES}

Connection to the drum for lifting shall be with a lifting attachment designed for lifting 55 -gal removable-head (but with the head installed) drums by the chime and having a rated load in excess 
of $657.7 \mathrm{~kg}(1,450 \mathrm{lb})$. The actual lift shall be by crane or other suitable means. No pick points are provided on the drum other than the standard drum chime.

\subsection{TIEDOWN DEVICES}

There are no tiedown devices that are a structural part of the package; therefore, the 10-5$2 g$ requirement of 49 CFR 173 is not applicable.

Drums will be secured to the truck as specified in Part A, Section 4.2. 
HNF-SD-TP-SEP-051 Rev. 1

This page intentionally left blank. 


\subsection{PACKAGE CONTENTS}

\subsection{GENERAL DESCRIPTION}

The Concrete-Shielded RH TRU Waste Drum contents consist of 327 Building legacy waste (hot cell debris), typically comprised of the following: activated pin tubes, paper towels, grinding disks, cloth wipes and towels, plastic bags and vials; steel and aluminum tools and fixturing, manipulator boots, stainless steel wool, and broken glass. There will be no chemicals, free liquids, or absorbed organic liquids. No fuel debris will be included other than that which may be in smearable form on other debris:

The material to be shipped (legacy waste) consists primarily of nonradioactive materials that have been contaminated with radioactive materials. Therefore, on either a volume or weight basis, the majority of the contents can be expected to be made up of nonradioactive materials.

The debris will be placed in 1-gal paint cans prior to loading into the removable inner liner of the drum. The paint cans will be punctured to preclude any pressure buildup. The available space will accommodate up to three uncrushed paint cans. Crushed paint cans may also be used with an expected quantity of up to six. The actual limit shall be dictated by the activity assay, which shall not exceed the limits of the source term specified in this section.

\subsection{CONTENTS RESTRICTIONS}

The contents in each drum and in each shipment is limited without restriction to the isotope distribution as follows (Part B, Section 2.2).

- The surface dose rate per drum is limited to $1 \mathrm{mSv} / \mathrm{h}(100 \mathrm{mrem} / \mathrm{h})$.

- A drum may contain up to $100 \mathrm{~g}$ of fissile material.

- The quantity of material in any single drum cannot exceed a highway route controlled. quantity ( $\mathrm{HRCO}$ ). HRCO is defined as a quantity of material that is greater than $3000 \mathrm{~A}_{2} \mathrm{~s}$ or greater than $1,000 \mathrm{TBq}(27,000 \mathrm{Ci})$, whichever is less (49 CFR 173.403).

- The number of drums allowed per shipment is limited due to fissile material content. If each drum in a shipment is fissile excepted $(15 \mathrm{~g}$ or less total fissile material), up to 30 drums may be shipped. However, if any drum has more than $15 \mathrm{~g}$ of fissile material, the total amount of fissile material in the shipment will be limited to $300 \mathrm{~g}$ (see Part B, Sections 2.2 and 6.0).

- The contents shall not contain chemicals, free liquids, or absorbed organic liquids. There shall be no fuel debris other than that which may be in smearable form on other debris. 
HNF-SD-TP-SEP-051 Rev. 1

This page intentionally left blank. 
HNF-SD-TP-SEP-051 ReV. 1

\subsection{TRANSPORTATION SYSTEM}

\subsection{TRANSPORTER}

The transport vehicle shall consist of a flatbed truck or trailer, with a wooden deck, having sufficient capacity for the intended load. This SEP allows decks up to $238.8 \mathrm{~cm}(94 \mathrm{in}$.) wide. Significantly wider trucks, such as lowboys, will require increased tiedown tension and must be evaluated prior to use.

This is a deviation from SD-RE-SAP-043, which specifies either a closed or stake-bed truck for intra-area shipments and a closed truck for interarea shipments. A flatbed truck is acceptable in this case due to the significantly improved container design and tiedown requirements. The current container uses a substantial steel inner container with a bolted cover versus the plastic bag used in SD-RE-SAP-043. In addition, the inner container is the primary containment rather than the drum, as is the case in SD-RE-SAP-043.

The total number of drums allowed per shipment shall not exceed the following:

- 30 drums provided that the content restrictions noted in Part A, Section 3.2 , and the radiation limits shown in Part A, Section 4.3.2, are met.

- The rated capacity of the transporter.

\subsection{TIEDOWN SYSTEM AND CARGO CONFIGURATION}

Drums shall be placed on the transport trailer in a double row down the longitudinal centerline. Stacking of drums is not permitted. The foremost pair must be positioned sufficiently far back from the front of the trailer to keep the front drums no less than $2.74 \mathrm{~m}(9 \mathrm{ft})$ from the driver if they are of maximum allowable activity. Drums of lesser activity may be closer, but in any event positioning shall not result in a dose rate greater than $0.02 \mathrm{mSv} / \mathrm{h}(2 \mathrm{mrem} / \mathrm{h})$ in the occupied space of the cab. The drums shall be secured as specified in this section and as illustrated in Figure A4-1. The specified tiedown method meets all requirements of $49 \mathrm{CFR} 393.100$ through 393.104 and provides restraint sufficient for loadings of at least $0.62 \mathrm{~g}$ forward and $0.5 \mathrm{~g}$ to the sides or rear.

Drums may be positioned in two separate arrays if needed to balance axle loading: one group near the front axles and the other group over the rear axles.

Primary restraint is provided by $2 \times 4$-in. wooden cleats nailed to the trailer deck. Over-the-top tiedown straps are necessary to prevent tipping. A pair of $2 \times 6-i n .$, or larger, wooden corner boards shall be installed longitudinally along both top edges of the drum array to distribute strap loads and prevent straps from slipping off the drums. Each transverse pair of drums shall be secured by one strap, located on the centerline of the drums.

It should be noted that within the tiedown analysis contained in Part B, Section 10.0, a minimum strapping tension requirement of $3,366.7 \mathrm{~kg}(3,013 \mathrm{lb})$ is specified. In the event that no tension measuring equipment is available, standard rigging/securing tensioning practices shall be used.

All components of the tiedown assemblies, including the attachment points on the vehicle, shall have a working load limit of at least $1,366.7 \mathrm{~kg}(3,013 \mathrm{lb})$. Web straps shall be used due to 
Figure A4-1. Truck Loading Arrangement and Details.

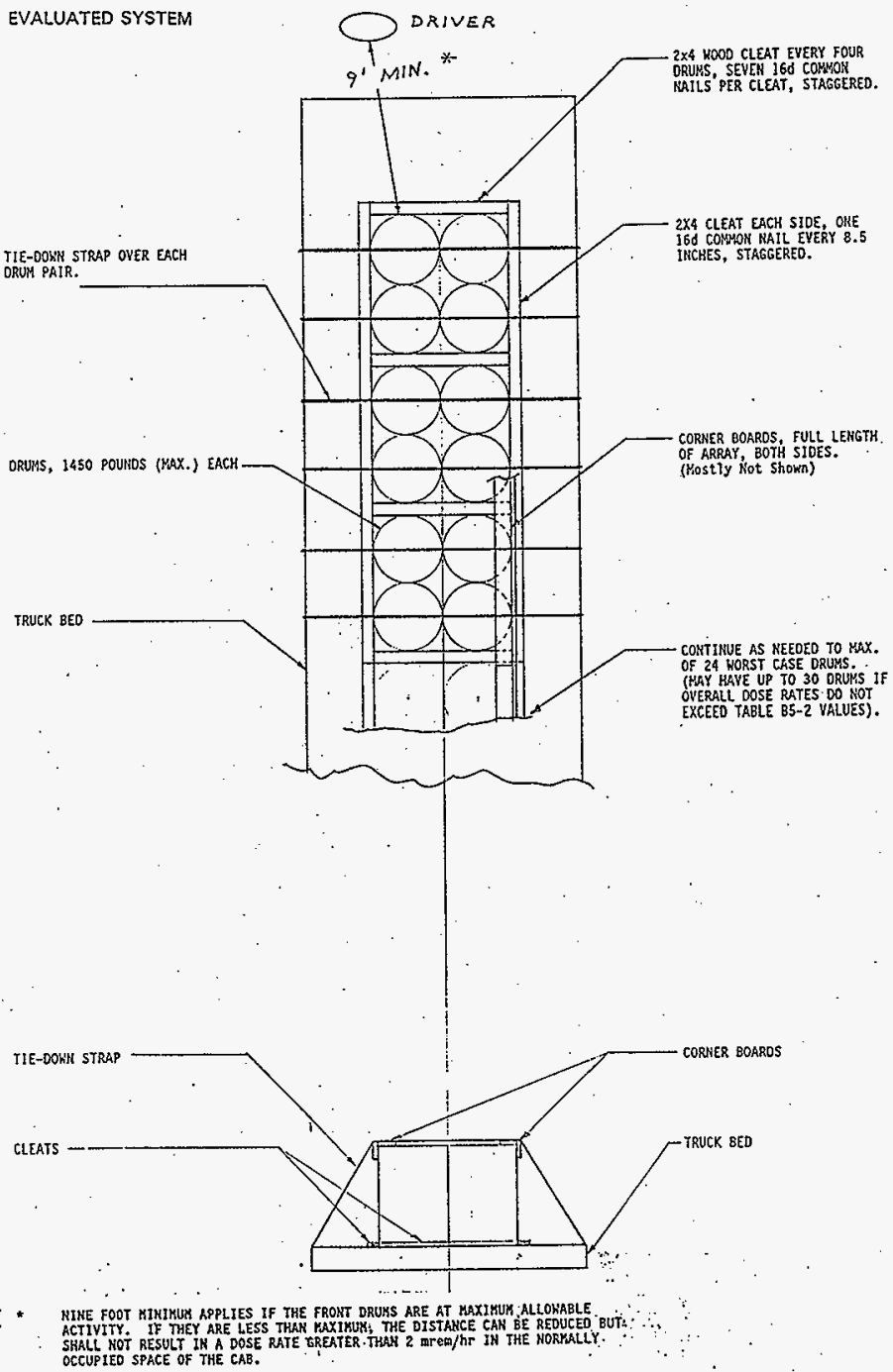


the need for the tiedown to slip slightly on the corner boards during tightening. It may be helpful, during the tightening process, to rap the corner boards with a hammer adjacent to the strap to encourage the slip that must occur for the tension to equalize.

All tiedown hardware (straps, tighteners, and anchor points) shall be inspected prior to use to verify there is no damage or significant wear that could affect their satisfactory performance.

Wooden $2 \times 4$-in. cleats nailed to the truck deck provide the primary lateral and fore/aft restraint for normal conditions. Nailing requirements are shown in Figure A4-1.

Cleats shall be installed on both sides and in front and back of the drum array. In addition, cleats shall be installed between each group of four drums. These intermediate cleats limit the potential load on any one cleat to that due to four drums.

\subsection{SPECIAL TRANSFER REQUIREIMENTS}

\subsubsection{Routing and Access Control}

Shipments shall be on Hanford Site roads between the 300 Area and the Transuranic Waste Storage and Assay Facility (TRUSAF)/Solid Waste facilities in 200 West Area. The route from the 300 Area to the Wye Barricade shall be by Route 4 South, and road closure is required for that segment. The route from the Wye Barricade to the 200 West Area shall be by Route 4 South and Route 3 , and road closure is not required.

\subsubsection{Radiological Limitations}

The dose rates for the transport vehicle are limited to the following.

- The dose rate at any point $2 \mathrm{~m}$ from the vehicle edge is limited to $0.1 \mathrm{mSv} / \mathrm{h}$ (10 $\mathrm{mrem} / \mathrm{h})$.

- A maximum dose rate of $0.02 \mathrm{mSv} / \mathrm{h}(2 \mathrm{mrem} / \mathrm{h})$ for a nonradiation worker or $0.05 \mathrm{mSv} / \mathrm{h}$ ( $5 \mathrm{mrem} / \mathrm{h}$ ) for a radiation worker is allowed in any normally occupied space in the vehicle.

The dose rate to the occupied space of the vehicle cannot be exceeded, but the addition of supplemental shielding is an acceptable method of reducing the dose rate to an acceptable level.

Surface contamination limits for the outside of the drum are specified in Table A4-1.

\subsubsection{Speed Limitations}

The risk evaluation does not impose a more restrictive speed limit than the normal highway speed of $88.5 \mathrm{~km} / \mathrm{h}(55 \mathrm{mph})$. During intersection type turns, speed shall be limited to $8 \mathrm{~km} / \mathrm{h}$ (5 mph) maximum. 
Table A4-1. External Container Contamination Limits.

\begin{tabular}{|c|c|c|}
\hline \multirow{2}{*}{ Contaminant } & \multicolumn{2}{|c|}{ Maximum permissible limits } \\
\hline & $\mu \mathrm{Ci} / \mathrm{cm}^{2}$ & $\mathrm{dpm} / \mathrm{cm}^{2}$ \\
\hline $\begin{array}{l}\text { Beta-gamma emitting radionuclides; all radionuclides with half- } \\
\text { lives less than ten days; natural uranium; natural thorium; } \\
\text { uranium-235; uranium-238; thorium-232; thorium- } 228 \text { and } \\
\text { thorium-230 when contained in ores or physical concentrates }\end{array}$ & $10^{.5}$ & 22 \\
\hline All other alpha emitting radionuclides & $10^{-6}$ & 2.2 \\
\hline
\end{tabular}

Source: 49 CFR 173.443, "Shippers-General Requirements for Shipments and Packagings," Code of Federal Regulations, as amended.

\subsubsection{Environmental Conditions}

Loaded Concrete-Shielded RH TRU Waste Drums shall not be transported when there is snow or ice on the roadway or when the ambient temperature is below $-12.2{ }^{\circ} \mathrm{C}\left(10^{\circ} \mathrm{F}\right)$. This temperature limit is dictated by the steel used in the inner cavity.

\subsubsection{Frequency of Use and Mileage Limitations}

Within the confines of the current program, the packaging is a single-use container. It will be loaded, transported to TRUSAF/Solid Waste, and stored for an indefinite time. Any future movement or reuse of the packaging would have to be addressed at that time.

A maximum of eight shipments is allowed. A maximum of 30 drums may be shipped on one truck.

The mileage per trip shall not exceed $40.2 \mathrm{~km}$ (25 mi). This limits the route to that specified in Section 4.3.1.

Use of this SEP is limited to a period of one year from the date of the first shipment. 
HNF-SD-TP-SEP-051 Rev. 1

\subsection{ACCEPTANCE OF PACKAGING FOR USE}

\subsection{NEW PACKAGING}

New packagings shall be fabricated to the requirements of $\mathrm{H}-3-304541$ (drum) and $\mathrm{H}-3-$ 304558 (removable liner). Any changes to the drawings will require review by Packaging Engineering for effects on the SEP and could necessitate an engineering change notice to the SEP.

\subsubsection{Acceptance Requirements}

Newly fabricated Concrete-Shielded RH TRU Waste Drums shail be inspected for compliance to the requirements of the applicable drawings. The inspection may be performed by either the fabricator's or the user's Quality Assurance/ Quality Control function. In either case, evidence of a satisfactory inspection shall be provided. As a minimum, acceptable verification shall be provided to assure that the procured drums (prior to modification and addition of shielding) are certified as U.S. Department of Transportation Type A packaging, that other materials meet the drawing requirements and that all welding meets ANSI/AWS D1.1-89 (AWS 1989) inspection requirements (as a minimum).

\subsubsection{Inspection and Testing}

The Concrete-Shielded RH TRU Waste Drum is a single-use item; therefore, every drum loaded will be a new drum. It will be loaded, transported to TRUSAF/Solid Waste, and placed in indefinite storage. Damage and deterioration associated with multiple usage will not occur. There are no testing requirements for this packaging.

The following pre-use checks are necessary to identify any damage or deterioration that might have occurred to new (empty) drums during storage or transit.

1. Visually verify that there is no damage to the drum, drum lid, gasket, closure ring, or sealing surface such as that which might be caused by dropping or other abuse.

2. Visually verify that there is no damage to the inner cavity cover gasket,'sealing surface, or bolts.

3. Visually verify that the foam impact limiter is not missing.

4. Visually verify that the Nucfil filters are installed in both the inner cavity cover and the drum lid and that they are not damaged.

\subsection{PACKAGING FOR REUSE}

The packaging is not authorized for reuse. 
HNF-SD-TP-SEP-051 ReV. 1

This page intentionally left blank.

A5-2 


\subsection{OPERATING REQUIREMENTS}

\subsection{GENERAL REOUIREMENTS}

The following requirements apply to the use of the packaging. Specific operating procedures, with appropriate Quality Assurance/Quality Control hold points, shall be written by the user and approved by Packaging Engineering prior to use to ensure the requirements of the SEP are met.

For loading/unloading operations, the following shall be inspected or verified, as appropriate.

1. Visually inspect container exterior for damage.

2. Visually inspect the drum seal and sealing surfaces for damage.

3. Visually inspect the inner cavity gasket and sealing surfaces for damage.

4. Verify torquing of inner cavity closure bolts to a minimum of $25 \mathrm{ft}-\mathrm{lb}$.

5. Verify torquing of the drum lid locking ring bolt to $40 \mathrm{ft}-\mathrm{lb}$ (nominal).

6. Visually inspect tiedown hardware for loose connections, cracks, or damage.

7. Verify proper positioning on, and tiedown to, the transporter per Figure A4-1.

8. Verify no more than eight shipments are made.

9. Verify no more than 30 drums per shipment provided the drums are fissile excepted. If the drums are not fissile excepted, verify that there is no more than $300 \mathrm{~g}$ fissile material per shipment and less than $100 \mathrm{~g}$ fissile material per drum.

\subsection{LOADING PACKAGE}

The following loading steps include some that are of concern only to laboratory operations and are subject to change by the laboratory with no effect on this SEP. Those steps identified with an * are pertinent to the SEP and may not be changed without review by Packaging Engineering.

1. Remove drum lid, inner cavity cover, foam impact limiter, steel shield plug, and removable liner.

2.* Perform pre-use inspection of drum per Section 5.1.2 and document inspection.

3. Survey loaded paint cans for compliance with the fissile material limits of this SEP (gamma scan, assay, dose rate, punctures, or other as applicable).

NOTE: The contents in each drum and in each shipment are limited without restriction to the isotope distribution as follows.

- The surface dose rate per drum is limited to $1 \mathrm{msv} / \mathrm{h}(100 \mathrm{mrem} / \mathrm{h})$.

- A drum may contain up to $100 \mathrm{~g}$ of fissile material. 
- The quantity of material in any single drum cannot exceed an $\mathrm{HRCQ}$. HRCQ is defined as a quantity of material that is greater than $3000 \mathrm{~A}_{2} \mathrm{~s}$ or greater than $1,000 \mathrm{TBq}(27,000 \mathrm{Ci})$, whichever is less (49 CFR 173.403).

- The number of drums allowed per shipment is limited due to fissile material content. If each drum in a shipment is fissile excepted (15 $\mathrm{g}$ or less total fissile material), up to 30 drums may be shipped. However, if any drum has more than $15 \mathrm{~g}$ of fissile material, the total amount of fissile material in the shipment will be limited to $300 \mathrm{~g}$ (see Part B, Sections 2.2 and 6.0 ).

- The contents shall not contain chemicals, free liquids, or absorbed organic liquids. There shall be no fuel debris other than that which may be in smearable form on other debris.

4. Transfer drum liner into the cell per laboratory procedure.

5. Make arrangements with TRUSAF/Solid Waste to accomplish any advance waste certification steps that might preclude problems concerning acceptance of the waste at TRUSAF. (The current understanding is that the drum weight prevents $x$-raying at TRUSAF and that alternative means will be necessary to verify contents.)

6. Load cans into liner (maximum of three uncrushed or six crushed depending on the activity assay results [cannot exceed limits of the specified source term]).

7. Position the drum horizontally outside the cell port.

8. Transfer loaded liner out of the cell and into the drum per laboratory procedure.

9. Check dose rate at exterior surface of drum $(<100 \mathrm{mrem} / \mathrm{h})$.

10. Rotate drum to partially or fully upright position (per laboratory procedure).

11. Place steel shield plug in mouth of drum cavity.

12. Rotate drum to vertical (if not already).

13.* Install foam impact limiter on top of shield plug.

14.* Place inner cavity cover (with gasket) in position.

15.* Chieck dose rate at exterior surfaces of drum. If above acceptable limit of 100 $\mathrm{mrem} / \mathrm{h}$, return contents to the cell.

16.* Install inner cavity cover bolts and torque to $25 \mathrm{ft}-\mathrm{lb}$ minimum.

17.* Install drum lid and locking ring with bolt and lock nut. Position the lock nut between the locking ring lugs. Torque the locking ring bolt once to a nominal $40 \mathrm{ft}-\mathrm{lb}$ and tighten the lock nut. 
18.* Check that external smearable contamination is within the limits of 49 CFR 173.443 (Table A4-1).

19. Transfer the loaded drum to holding area or to the transporter.

\subsection{TRUCK LOADING AND TRANSPORTING}

Those steps identified with an * are pertinent to the SEP and may not be changed without review by Packaging Engineering.

1.* Locate the first pair of drums a minimum of $2.74 \mathrm{~m}(9 \mathrm{ft})$ from the occupied space of the truck cab if the drums contain the maximum allowable activity. Drums of less than maximum activity may be placed closer than $2.74 \mathrm{~m}(9 \mathrm{ft})$, but shall be positioned to limit the dose rate in the cab to a maximum of $0.02 \mathrm{mSv} / \mathrm{h}(2 \mathrm{mrem} / \mathrm{h})$ for a nonradiation worker or $0.05 \mathrm{mSv} / \mathrm{h}(5 \mathrm{mrem} / \mathrm{h})$ for a radiation worker.

2.* Position and secure the loaded drums on the transporter per Part A, Section 4.2, and Figure A4- 1 .

3.* Check that all requirements of Part A, Section 4.3 , are met.

4.* Prepare shipping papers.

\subsection{UNLOADING PACKAGE}

The step identified with an * is pertinent to the SEP and may not be changed without review by Packaging Engineering.

1. Remove the transport tiedowns and corner boards.

2. Lift the drums individually with a crane or other lifting method in conjunction with a suitable drum lifting attachment. Place in required location.

3.* Receive shipment (complete shipping papers). 
HNF-SD-TP-SEP-051 Rev. 1

This page intentionally left blank.

A6-4 


\subsection{QUALITY ASSURANCE REQUIREMENTS}

\subsection{GENERAL REQUIREMENTS}

Quality assurance requirements related to design, procurement, and fabrication of the Concrete-Shielded RH TRU Waste Drum shall be based on the Hanford Site hazardous material shipping program as described in HNF-PRO-154 and to applicable portions of EBU-OAPP-001, Quality Assurance Program Plan for Project Hanford Management Contract Work (WMNW 1997).

Packaging Engineering shall be responsible for fabrication of the Concrete-Shielded RH TRU Waste Drum to the requirements of drawings $\mathrm{H}-3-304541$ (drum) and $\mathrm{H}-3-304558$ (liner). inspection requirements shall be as required by EBU-QAP-001, Quality Assurance Procedures:

The following features or operations are considered critical to fabrication:

- Materials for inner cavity fabrication

- Welding and weld inspection on the inner cavity

- Concrete density.

The Project Hanford Management Contract user shall be responsible for packaging and shipping each drum in compliance with a Project Hanford Management Contractor-approved safe operating procedure, the requirements specified in this SEP, and those requirements contained in HNF-P.RO-154 and HNF-MP-0599, Project Hanford Quality Assurance Program Description (FDH 1997).

\subsection{SEP CONTROL. SYSTEM}

The Concrete-Shielded RH TRU Waste Drum SEP shall be a supporting document to ensure that only an up-to-date SEP is used for transfer of radioactive materials. SEP changes shall be provided as engineering change notices and shall be provided to all holders of this SEP. SEP review records (comments) shail be retained by Packaging Engineering for the life of the system. These records are not considered quality assurance records, but provide historical evidence of SEP review and approval. 
HNF-SD-TP-SEP-051 Rev. 1

This page intentionally left blank.

A7-2 


\subsection{MAINTENANCE}

Due to the single-use nature of the Concrete-Shielded RH TRU Waste Drum and the one-year limit on this SEP, there are no maintenance requirements for either the container or associated tiedown hardware. Pre-use inspections for new containers are covered in Part A, Section 5.1. Preuse inspections for tiedown hardware are covered in Part A, Section 4.2. 
HNF-SD-TP-SEP-051 Rev. 1

This page intentionally left blank.

A8-2 
HNF-SD-TP-SEP-051 Rev. 1

\subsection{REFERENCES}

49 CFR 173, "Shippers-General Requirements for Shipments and Packagings," Code of Federal Regulations, as amended.

49 CFR 393, "Parts and Accessories Necessary for Safe Operation," Code of Federal Regulations, as amended.

EBU-QAP-001, Quality Assurance Procedures, Engineering Business Unit, Waste Management Federal Services, Inc., Northwest Operations, Richland, Washington.

HNF-PRO-154, Responsibilities and Procedures for All Hazardous Material Shipments, Fluor Daniel Hanford, Inc., Richland, Washington.

AWS, 1989, Structural Welding Code--Steel, ANSI/AWS D1.1-89, Amẹrican Welding Society, Miami, Florida.

FDH, 1997, Project Hanford Quality Assurance Program Description, HNF-MP-0599, Rev. 1, Fluor Daniel Hanford, inc., Richland, Washington.

SD-RE-SAP-033, Transuranic Radioactive Material in the 55-Gallon Drum, HCS-042-002, Safety Analysis Report for Packaging (Onsite), Westinghouse Hanford Company, Richland, Washington.

SD-RE-SAP-043, Safety Analysis Report for Packaging 1Onsitel Internally Shielded 55-Gallon Drum, Westinghouse Hanford Company, Richland, Washington.

Willis, N. P., 1993, Hanford Site Solid Waste Acceptance Criteria, WHC-EP-0063-04, Westinghouse Hanford Company, Richland, Washington.

WMNW, 1997, Quality Assurance Program Plan for Project Hanford Management Contract Work, EBU-OAPP-O01, Rev. 1, Engineering Business Unit, Waste Management Federal Services, Inc., Northwest Operations, Richland, Washington. 
HNF-SD-TP-SEP-051 Rev. 1

This page intentionally left blank. 
HNF-SD-TP-SEP-051 Rev. 1

10.0 APPENDIX: DRAWINGS

H-3-304541, Rev. 1, Concrete-Lined Waste Package Assembly (Sheet 1 of 2) and Details (Sheet 2 of 2)

H-3-304558, Rev. 1, Concrete-Lined Waste Package Sleeve Assembly (Removable Liner) 
HNF-SD-TP-SEP-051 Rev. 1

This page intentionally left blank. 


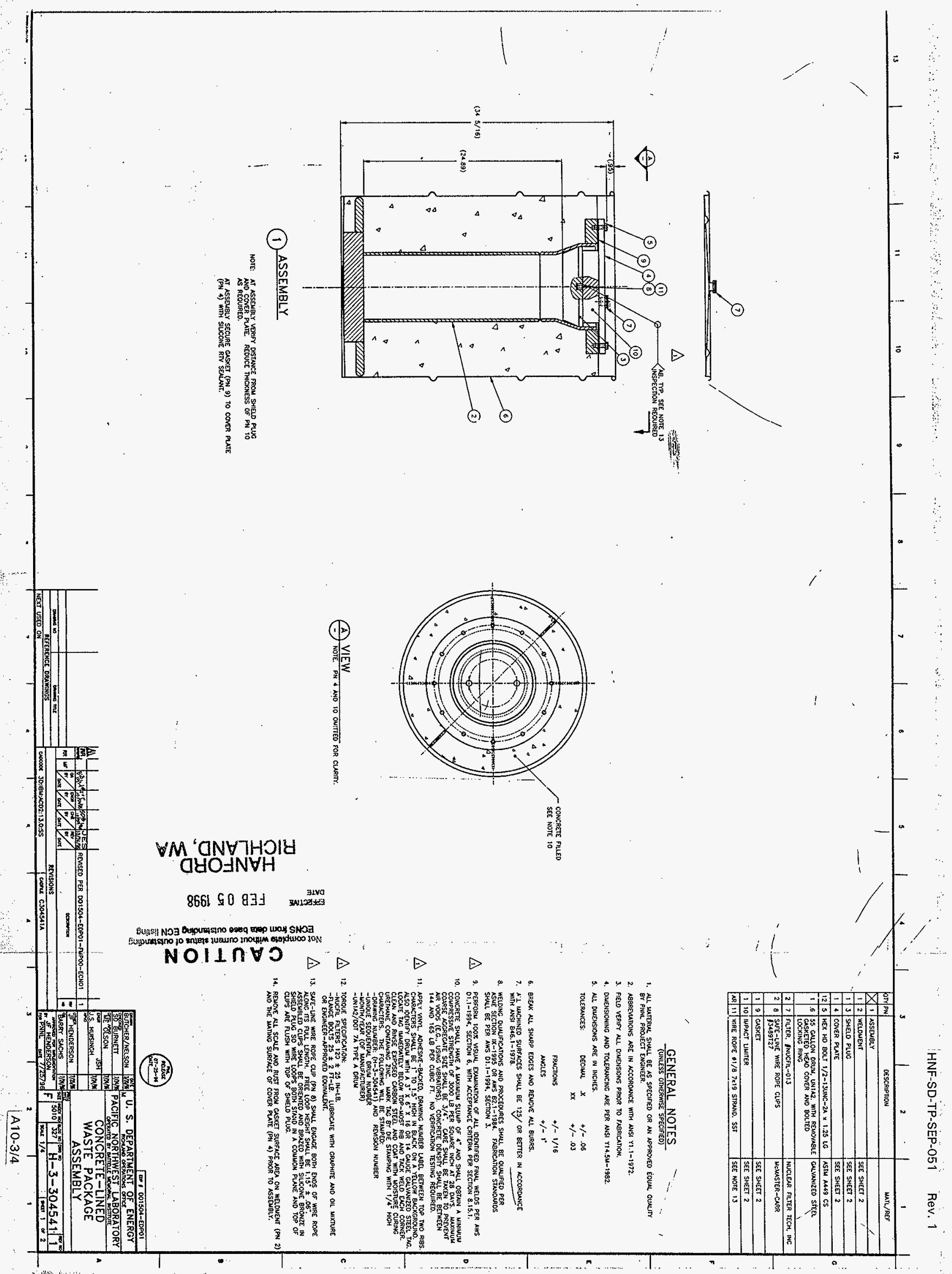




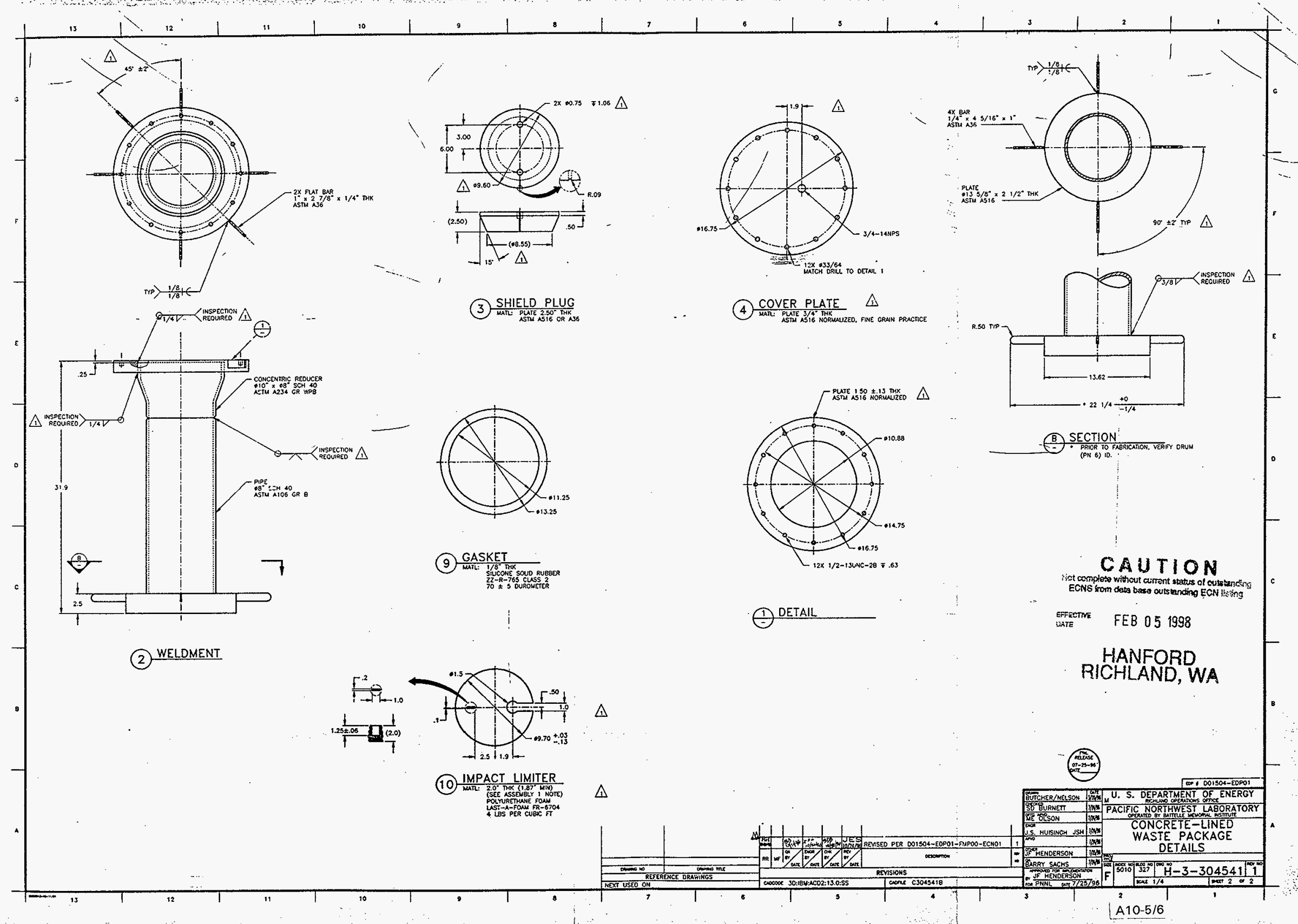




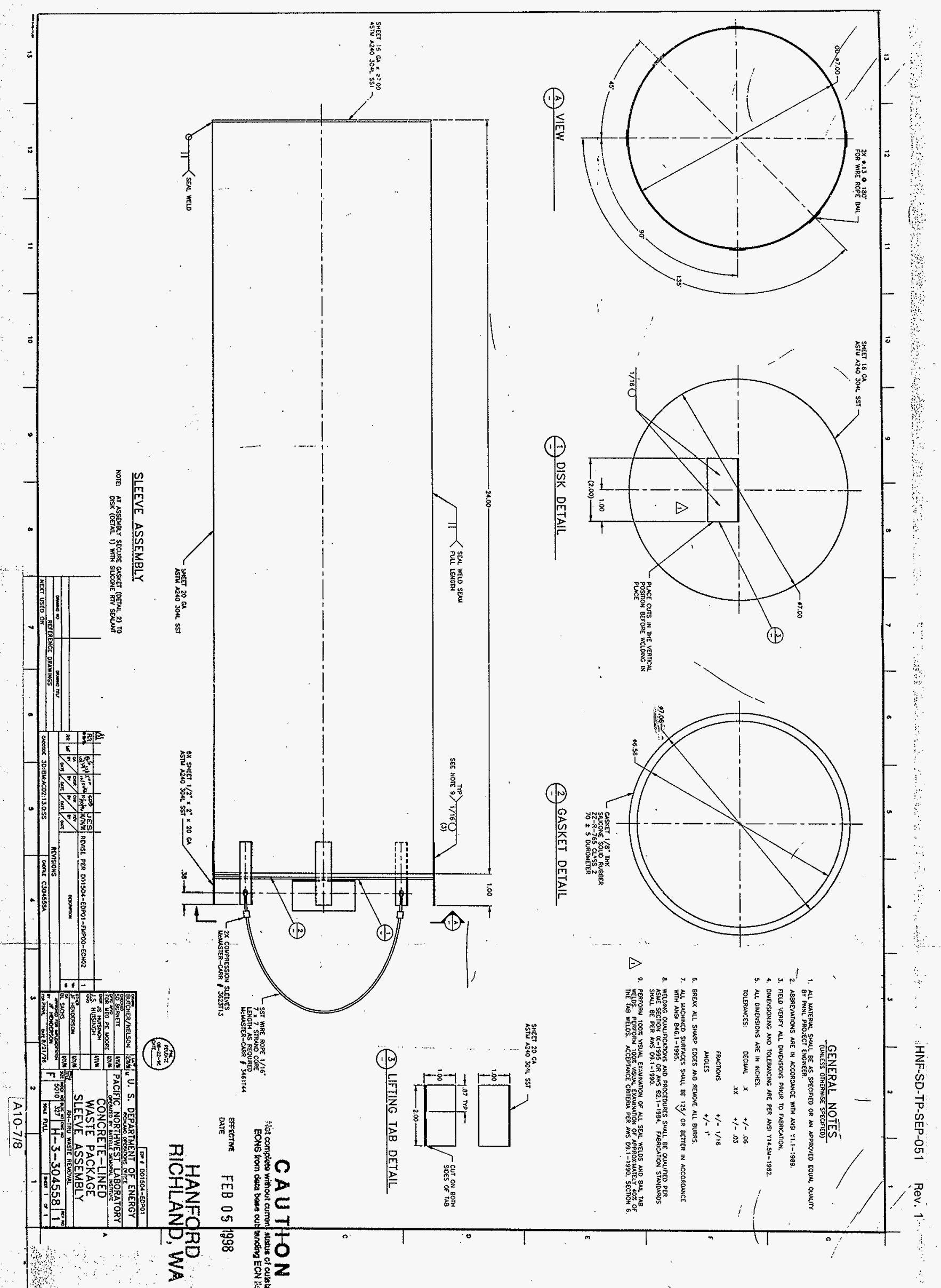


HNF-SD-TP-SEP-051 Rev. 1

PART B: PACKAGE EVALUATION

\subsection{INTRODUCTION}

\subsection{SAFETY EVALUATION METHODOLOGY}

This safety evaluation for packaging (SEP) for the Concrete-Shielded Remote-Handled Transuranic Waste (RH TRU) Drum used two existing safety analysis reports for packaging (SARP) for guidance. They are the Transuranic Radioactive Material in the 55-Gallon Drum, Safety Analysis Report for Packaging (Onsite) (SD-RE-SAP-033) and the Safety Analysis Report for Packaging (Onsite) Internally Shielded 55-Gallon Drum (SD-RE-SAP-043).

The initial design concept was for a drum very similar to that authorized by SD-RE-SAP-O43. That drum utilized a nonsealed inner cavity and relied on the drum itself for primary containment. A plastic bag provided secondary containment. The shipper did, however, want to secure relief from the interarea restrictions imposed by that SARP (maximum of three $657.7-\mathrm{kg}(1,450-\mathrm{lb}) \mathrm{drums}$, closed vehicle) because the currently anticipated need is to ship 80 drums.

The final design included a stronger inner container that features a bolted gasketed cover. Primary containment is provided by this inner container rather than by the drum shell itself. A plastic bag is no longer required.

Because the new packaging is basically similar to, but improved over, the packaging evaluated and approved by SD-RE-SAP-043, Section 3.0, "Standards and Analysis," and Section 4.0, "Safety Controls," and supporting documents referenced therein, these sections are incorporated into this SEP by reference. They provide the documentation that approves the basic concrete-shielded drum as a Type A shipping container. The substantial inner container in the new design provides a very significant improvement over that original design. The inner container is evaluated in Section 7.0 of this SEP.

\subsection{EVALUATION SUMMARY AND CONCLUSIONS}

The Concrete-Shielded RH TRU Drum meets the established onsite transportation safety requirements through supplemental design improvements and administrative controls. The risk analysis supports shipment of up to $30,657.7-\mathrm{kg}(1,450-\mathrm{lb})$ drums per shipment, up to eight shipments total, and use of a flatbed truck with the restrictions noted below.

The source term is limited without restriction to the isotope distribution as follows.

- The surface dose rate per drum is limited to $1 \mathrm{mSv} / \mathrm{h}(100 \mathrm{mrem} / \mathrm{h})$.

- A drum may contain up to $100 \mathrm{~g}$ of fissile material.

- The quantity of material in any single drum cannot exceed a highway route controlled quantity (HRCO). HRCQ is defined as a quantity of material that is greater than $3000 \mathrm{~A}_{2} \mathrm{~s}$ or greater than $1,000 \mathrm{TBq}(27,000 \mathrm{Ci})$, whichever is less. 
- The number of drums allowed per shipment is limited due to fissile material content. If each drum in a shipment is fissile excepted $(15 \mathrm{~g}$ or less total fissile material), up to 30 drums may be shipped. However, if any drum has more than $15 \mathrm{~g}$ of fissile material, the total amount of fissile material in the shipment will be limited to $300 \mathrm{~g}$ (see Part B, Sections 2.2 and 6.0).

The dose rates for the transport vehicle are limited to the following.

- The dose rate at any point $2 \mathrm{~m}$ from the vehicle edge is limited $0.1 \mathrm{mSv} / \mathrm{h}(10 \mathrm{mrem} / \mathrm{h})$ (supplemental shielding may be added to meet this limit).

- A maximum dose rate of $0.02 \mathrm{mSv} / \mathrm{h}(2 \mathrm{mrem} / \mathrm{h})$ for a nonradiation worker or $0.05 \mathrm{mSv} / \mathrm{h}(5 \mathrm{mrem} / \mathrm{h})$ for a radiation worker is allowed in any normally occupied space in the vehicle.

Road closure is necessary from the 327 Building to the Wye Barricade. Specific tiedown requirements are provided. Restrictions are imposed on road conditions, ambient temperature, speed, radioactive material quantities, and package dose rates.

As shown in the Section 7.0, "Structural Evaluation," the Concrete-Shielded RH TRU Drum will maintain containment of the contents through all normal transfer conditions. Maintaining containment is demonstrated by comparing the evaluated stresses to ASME (1992) allowable stress values for the materials involved.

All evaluations have positive margins of safety with respect to the ASME (1992) allowables; therefore, this evaluation demonstrates that the Concrete-Shielded RH TRU Drum is safe for onsite transfers of 327 Building hot cell legacy waste within the limits of this SEP.

\subsection{REFERENCES}

ASME, 1995, ASME Boiler and Pressure Vessel Code, Section VIll, Division 1, American Society of Mechanical Engineers, New York, New York.

WHC-SD-SAP-033, Transuranic Radioactive Material in the 55-Gallon Drum, HCS-042-002, Safety Analysis Report for Packaging (Onsitel, Westinghouse Hanford Company, Richland, Washington.

WHC-SD-SAP-043, Safety Analysis Report for Packaging (Onsitel, Internally Shielded 55-Gallon Drum, Westinghouse Hanford Company, Richland, Washington. 


\subsection{CONTENTS EVALUATION}

\subsection{CHARACTERIZATION}

\subsubsection{Radioactive Source Term}

An estimate of the ratio of radionuclides contained in one drum was provided by the shipper (see Part $B$, Section 5.2). It was estimated using the relative concentrations calculated from MFA-1 inventory and ORIGEN2 runs, which were normalized to a ${ }^{137} \mathrm{Cs}$ activity of $3.7 \times 10^{10} \mathrm{~Bq}(1 \mathrm{Ci})$. Since the original source term was supplied, the quantity of fissile material allowed in the drum was increased to $100 \mathrm{~g}$ combined with a limit on the surface dose rate of $1 \mathrm{msv} / \mathrm{h}(100 \mathrm{mrem} / \mathrm{h})$.

During the evaluation of a payload containing $100 \mathrm{~g}$ of fissile material per drum, it was determined that the source term has a Transportation Hazard Indicator of 1 (THI-1) (Part B, Section 3.0), the highest category, so it is not necessary to limit the isotope distribution to that shown in Part B, Section 5.2. Therefore, the source term was evaluated with respect to criticality based on a maximum fissile material content of $100 \mathrm{~g}$ (Part B, Section 6.0). The shielding evaluation was done using the original source term with $100 \mathrm{~g}$ of fissile material and with the gamma- and beta-emitting isotopes scaled to produce a dose rate on the surface of the drum of $1.0 \mathrm{mSv} / \mathrm{h}(100 \mathrm{mrem} / \mathrm{h})$ (Part B, Section 5.0$)$. The shielding and criticality evaluations, plus a limit on the total radioisotope inventory with respect to $\mathrm{HRCO}$ resulted in the restrictions shown in Part B, Section 2.2.

\subsubsection{Chemical Source Term}

Specific chemical source term information is not available. The material is identified as hot cell legacy waste, which typically consists of the following: activated pin tubes, paper towels, grinding disks, cloth wipes and towels, plastic bags and vials, steel and aluminum tools and fixturing, manipulator boots, stainless steel wool, and broken glass. There will be no chemicals, free liquids, or absorbed organic liquids. No fuel debris will be included other than that which may be in smearable form on other debris.

\subsection{RESTRICTIONS}

Drum contents are estimated to be three uncrushed, or six crushed, 1-gal paint cans. Cans shall be punctured to preclude pressurization.

The contents in each drum and in each shipment are limited without restriction to the isotope distribution as follows.

- The surface dose rate per drum is limited to $1 \mathrm{mSv} / \mathrm{h}(100 \mathrm{mrem} / \mathrm{h})$.

- A drum may contain up to $100 \mathrm{~g}$ of fissile material.

- The quantity of material in any single drum cannot exceed an HRCQ. HRCQ is defined as a quantity of material that is greater than $3000 \mathrm{~A}_{2} \mathrm{~s}$ or greater than $1,000 \mathrm{TBq}$ $(27,000 \mathrm{Ci})$, whichever is less (49 CFR 173.403).

- The number of drums allowed per shipment is limited due to fissile material content. If each drum in a shipment is fissile excepted (15 g or less total fissile material), up to 
30 drums may be shipped. However, if any drum has more than $15 \mathrm{~g}$ of fissile material, the total amount of fissile material in the shipment will be limited to $300 \mathrm{~g}$ (see Part B, Sections 2.2 and 6.0 ).

- The contents shall not contain chemicals, free liquids, or absorbed organic liquids. There shall be no fuel debris other than that which may be in smearable form on other debris.

Additional limits on the dose rate for the entire shipment with respect to the driver position and the vehicle are shown in Part B, Section 1.2.

\subsection{SIZE AND WEIGHT}

The maximum estimated payload weight is $13.6 \mathrm{~kg}(30 \mathrm{lb}$ ) (up to six paint cans at $2.3 \mathrm{~kg}$ [5 lb] each). The tare weight of each paint can is estimated at $0.34 \mathrm{~kg}(0.75 \mathrm{lb})$.

\subsection{CONCLUSIONS}

The radiological source term allowed per Concrete-Shielded RH TRU Drum is limited (without restriction to the radioisotope distribution) to that which contains up to $100 \mathrm{~g}$ of fissile material, produces a surface dose rate of $1 \mathrm{mSv} / \mathrm{h}(100 \mathrm{mrem} / \mathrm{h})$, and is less than an HRCQ. If the fissile loading of any drum in a shipment exceeds $15 \mathrm{~g}$, then the amount of fissile material in the entire shipment is limited to $300 \mathrm{~g}$. Up to 30 drums may be shipped at a time provided that the fissile material limits and dose rate limits to the driver are met.

\subsection{REFERENCE}

Simmons, G. L., J. J. Regimbal, J. Greenborg, E. L. Kelly, Jr., and H. H. van Tuyl, 1967, ISOSHLD-ll: Code Revision to Include Calculation of Dose Rate from Shielded Bremsstrahlung Sources, BNWL-236, Supplement 1, Battelle-Northwest Laboratories, Richland, Washington. 


\subsection{RADIOLOGICAL RISK EVALUATION}

\subsection{INTRODUCTION}

The Concrete-Shielded RH TRU Drum is used to ship Type B quantities of hot cell debris from the 327 Building to the 200 Area or to another Hanford Site storage location. The waste is shipped in 55-gal steel drums, which have been modified to include a steel inner cavity and concrete shielding. The debris is classified as transuranic (TRU) waste and contains miscellaneous discarded hot cell materials. Radiological risks are evaluated to determine compliance with onsite transportation safety requirements per HNF-PRO-154, Responsibilities and Procedures for All Hazardous Material Shipments.

The maximum mileage per shipment will be $40.23 \mathrm{~km}(25 \mathrm{mi})$. The assumptions for the radiological risk evaluation are the following:

- Highway mode

- Closed roads when traveling south of the Wye barricade

- 8 shipments maximum

- $40.23 \mathrm{~km}$ (25 mi) per shipment.

The drums and liners are designed to withstand normal transportation conditions. For accident environments, the drums and liners must meet onsite transportation safety requirements as outlined in HNF-PRO-154 and Mercado (1994). The requisite safety is determined by a radiological risk evaluation that uses dose consequences, risk acceptance criteria, failure threshold values, and Hanford Site accident frequencies. For the evaluation, accidents are categorized as impact, crush, puncture, and fire. Risk acceptance criteria are outlined in Section 3.2. The dose consequence analyses results are discussed in Section 3.3. Failure thresholds are given in Section 3.4. The analysis of accident release frequencies for associated failure thresholds is given in Section 3.5. The accident frequencies, together with the dose values, provide the necessary input to provide an evaluation of acceptance of the risk related to the Concrete-Shielded RH TRU Drum shipping campaign as outlined.

\subsubsection{Discussion and Results}

The Concrete-Shielded RH TRU Drum failure thresholds were used to determine the total conditional probability of release for mechanical and thermal accident scenarios. The total conditional release probability was then multiplied by the Hanford Site annual accident rate to arrive at an annual accident release frequency. The annual release frequency was compared to the dose consequence results to determine acceptance (HNF-PRO-154 and Mercado 1994). For the concrete-shielded drums a comparison of the annual release frequency with the criteria determined from the dose consequence study showed the risks to be less than the required maximum of $10^{-7}$. For the drum shipments, applicable reduction factors lower the potential annual release frequency to below $10^{-7}$ and allow for eight shipments per year. Therefore, eight shipments per year of the Concrete-Shielded RH TRU Drums will comply with onsite transportation safety requirements.

\subsection{RISK ACCEPTANCE CRITERIA}

Graded dose limitations for probable, credible, and incredible accident frequencies ensure safety in radioactive material packaging and transportation (Mercado 1994). The dose limitations to the offsite and onsite individual for probable, credible, and incredible accident frequencies are presented in Table B3-1. 
Table B3-1. Risk Acceptance Criteria Limits (Effective Dose Equivalent).

\begin{tabular}{|l|l|l|l|}
\hline Description & Annual frequency & \multicolumn{1}{|c|}{$\begin{array}{c}\text { Onsite } \\
\text { dose limit } \\
\text { Sv (rem) }\end{array}$} & \multicolumn{1}{|c|}{$\begin{array}{c}\text { Offsite } \\
\text { dose limit } \\
\text { Sv (rem) }\end{array}$} \\
\hline Incredible & $<10^{-7}$ & None & None \\
\hline Incredible & $10^{-7}$ to $<10^{-6}$ & None & $.25(25)$ \\
\hline Credible & $10^{\cdot 6}$ to $10^{-3}$ & $.05(5)$ & $.005(.5)$ \\
\hline Probable & $10^{\cdot 3}$ to 1 & $.002(.2)$ & $.0001(.01)$ \\
\hline
\end{tabular}

\subsection{DOSE CONSEQUENCE ANALYSIS RESULTS}

The dose consequence study for the Concrete-Shielded RH TRU Drums is discussed in Part B, Section 4.6. The evaluation considers the results of an accident breaching a single drum and releasing $100 \%$ of the material at risk to the environment.

Because a scoping dose consequence analysis determined that the dose to the offsite individual exceeds $0.25 \mathrm{~Sv}(25 \mathrm{rem})$ for a single drum, the annual accident frequency is limited to $10^{-7}$ in order to meet the acceptance criteria of Table B3-1.

\subsection{PACKAGE FAILURE THRESHOLD ANALYSIS}

The failure thresholds of the Concrete-Shielded RH TRU Drum have been determined for impact, puncture, crush, and fire as follows:

- Impact: $\quad 37 \mathrm{~km} / \mathrm{h}(23 \mathrm{mph})$ velocity change on to a typical Hanford Site surface (see Part B, Section 7.13, for verification)

- Puncture: $\quad \mathrm{v} / \mathrm{r}$ ratio of $265 \mathrm{sec}^{-1}(\mathrm{v} / \mathrm{r}=$ velocity for small package puncture failure divided by the radius of the puncturing probe)

- Crush: Survives $7,257.5-\mathrm{kg}(16,000-\mathrm{lb})$ crush force in worst orientation (see Part $B$, Sections 7.11 and 7.13 , for verification)

- Fire: Fails any fire.

\subsection{ACCIDENT FREQUENCY ASSESSMENT}

\subsubsection{Approach}

The accident release frequency assessment is based on the assumption that all failure modes from the different forces described as impact, puncture, crush, and fire result in the same level of consequence. The union of the package conditional release probabilities from different scenarios with similar consequences is multiplied by the frequency of truck accidents to arrive at a total accident release frequency. 
The frequency $(F)$ of a truck accident is the product of the annual number of trips, the number of miles per trip, and the accident rate per mile.

$$
F=\frac{\text { number of trips }}{\text { year }} \times \frac{\text { miles }}{\text { trip }} \times \frac{\text { accidents }}{\text { mile }}
$$

Hanford Site truck accidents have been compiled in a report using Site-specific data (Green et al. 1996), which gives the accident rate for trucks as $2.0 \times 10^{-7}$ accidents per mile. For a shipment of radioactive materials north of the Wye Barricade that is carried out by trained truck drivers during daylight hours in good road conditions, a total reduction factor of 40 can be applied to lower the rate to $5 \times 10^{-9}$ (H\&R 1995) accidents per mile. Appendix B of Recommended Onsite Transportation Risk Management Methodology (H\&R 1995) summarizes statistics from the U.S. Department of Transportation and the studies conducted by Sandia National Laboratory on accident responses of small and large packages. The report recommends reducing truck accident rates by 10 for "safe" truck drivers, a factor of two for travel north of the Wye Barricade, and another factor of two for shipment of radioactive material. Travel south of the. Wye Barricade will occur only on closed roads, which may reduce accidents by another factor of 20 . However, this closed road reduction factor is ignored. The reduction factors are based on the following logic.

- Safe truck drivers: Hanford Site truck drivers have special training. Drivers must complete several driver's education courses, have a valid commercial driver's license with hazardous endorsement, complete specific training for HRCOs of radioactive material, and complete radiation worker and hazardous materials training. References show that drivers who participate in special safety programs reduce single-vehicle accident rates by up to a factor of 100 . The H\&R report (H\&R 1995) recommends using an overall accident reduction factor of 10 .

- Travel north of the Wye Barricade: The general population is excluded north of the Wye barricade. The roads are straight and generally flat. These conditions eliminate conditions caused by after-work activities, such as alcohol consumption and travel during limited visibility. Statistics show that the difference between travel during day and night leads to an accident reduction of 2.67. Therefore, although the ConcreteShielded RH TRU Drum is not limited to travel during daylight hours, a conservative factor of two reduction is recommended for travel north of the Wye Barricade because there is a constraint on traveling during adverse weather conditions that may affect visibility and because no alcohol consumption is permitted on the Hanford Site.

- Travel south of the Wye Barricade: Travel will occur south of the Wye Barricade on closed roads. Road closure reduces rear-end collision by a factor of 10 , and multiplevehicle accidents are reduced by another factor of 20 . However, only a reduction factor of 2 is applied in this analysis in order to be consistent with the approach to the portion of the shipment north of the Wye Barricade.

- Radioactive material: An additional factor of two is recommended based on the higher level of training required for drivers of vehicles carrying radioactive material and the higher level of caution that would be expected from drivers of cargos consisting of radioactive material.

Conditional release probabilities for fire, crush, impact, and puncture are determined for highway from a Sandia National Laboratory study for accidents involving small packages (Clarke et al. 1976) and from a Hanford Site risk management study (H\&R 1995). The conditional release probabilities are presented in the flow chart in Figure B3-1. 
HNF-SD-TP-SEP-051 ReV. 1
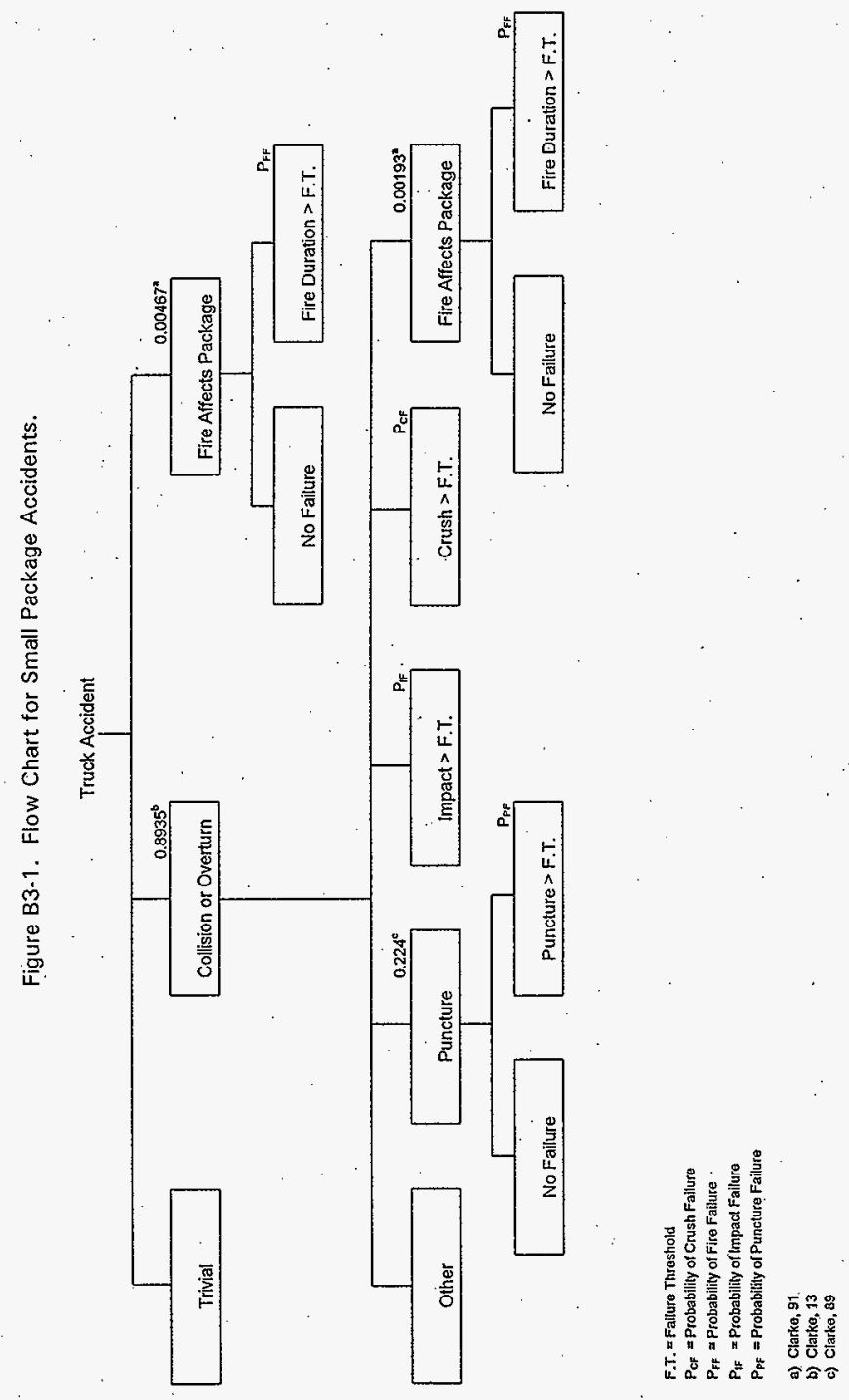


\subsubsection{Accident Release Frequency Analysis}

An accident sequence analysis is developed for each failure type (impact, puncture, crush, and fire) and presented in the flow chart in Figure B3-1. Information for the probability of occurrence and conditional probabilities of failure was taken from Clarke et al. (1976) and $H \& R$ (1995). Mechanical failure conditional probabilities are further subdivided into those affected by fire. The conditional probabilities are summed for comparison to the risk criteria. A summary of the conditional probabilities and summation are shown in Table B3-2.

Table B3-2. Failure Thresholds, Occurrence, and Conditional Failure Probabilities.

\begin{tabular}{|c|c|c|c|}
\hline Force type & Failure threshold & $\begin{array}{l}\text { Probability of } \\
\text { occurrence }\end{array}$ & $\begin{array}{c}\text { Conditional } \\
\text { probability of } \\
\text { failure }\end{array}$ \\
\hline Impact failure & $37 \mathrm{~km} / \mathrm{h}(23 \mathrm{mph})$ & 0.8935 & 0.10 \\
\hline Crush failure & $>>7,257.5 \mathrm{~kg}(16,000 \mathrm{lb})$ & $\sim 0$ & - \\
\hline Puncture failure & $265 \sec ^{-1}$ & $\begin{array}{l}0.8935 \times \\
0.224\end{array}$ & 0.008 \\
\hline Fire fallure & Fails any fire & $\begin{array}{l}0.00467+ \\
0.8935 x \\
0.00193= \\
0.00639\end{array}$ & 1 \\
\hline \multicolumn{3}{|c|}{ Total conditional release probability } & 0.0966 \\
\hline
\end{tabular}

The impact failure threshold was determined to be a $37-\mathrm{km} / \mathrm{h}(23-\mathrm{mph})$ change in velocity on to a typical Hanford Site surface (see Part B, Section 7.13 , for verification). The probability of occurrence of a collision or overturn event is $0.8935 \times \mathrm{F}$, and the conditional probability of impact failure is 0.10 .

Puncture probabilities are determined by the $\mathrm{v} / \mathrm{r}$ ratio, which is the puncture failure threshold velocity divided by the radius of the probe. The probability of occurrence of collision or overturn is 0.8935 . This is multiplied by the probability of a puncture accident $(0.224)$ and by the conditional failure probability for the $265 \mathrm{sec}^{-1}$ failure threshold, which is 0.008 .

The failure threshold for crush is greater than $7257 \mathrm{~kg}(16,000 \mathrm{lb})$; therefore, the conditional probability of failure due to crush is approximately equal to zero.

The drums are assumed to fail in any fire event.

3.5.2.1 Joint Probabilities. Conditional release probabilities and failure thresholds are summarized in Table B3-3. The joint probability is calculated by taking the union of events (McCormick 1981). The equation represents the sum of the probabilities of independent events while the subtracted terms eliminate double counting arising from the overlap caused by the intersection of the events. The general equation is given as: 


$$
\begin{gathered}
P\left(A_{1}+A_{2}+\ldots+A_{N}\right)=\sum_{n=1}^{N} P\left(A_{n}\right)-\sum_{n=1}^{N-1} \sum_{m=n+1}^{N} P\left(A_{n} A_{m}\right)+- \\
\ldots+(-1)^{N-1} P\left(A_{1} A_{2} \ldots A_{N}\right) .
\end{gathered}
$$

where

$$
\begin{aligned}
P(f \mid a) & =\text { the probability of fire given that an accident has occurred } \\
P(f c \mid a) & =\text { the probability of fire and crush given that an accident has occurred }
\end{aligned}
$$

and

P(FTE $f \mid f)=$ the probability that the failure threshold is exceeded by fire given that a fire has occurred

then the above equation can be expanded and written as:

$$
\begin{aligned}
P= & P(f \mid a) P(F T E f \mid f)+P(c \mid a) P(F T E c \mid c)+P(|| a) P(F T E \| \mid)+ \\
& P(p \mid a) P(F T E p \mid p)-P(f c \mid a) P(F T E f \mid f) P(F T E c \mid c)- \\
& P(f \mid a) P(F T E f \mid f) P(F T E|| \mid)-\ldots
\end{aligned}
$$

Thus, the values from the flow chart in Figure B3-1 and the conditional probabilities from Table B3-2 yield a total conditional release probability of 0.0966 .

\subsection{EVALUATION AND CONCLUSION}

Table B3-2 shows the conditional release probabilities calculated for each scenario and sums them to give a total conditional release probability. The summed probability is then multiplied by $F$, the frequency, to arrive at an annual accident release frequency. With a total conditional release probability of 0.0966 , the reduced accident rate of $5 \times 10^{-9}$, and the $10^{-7}$ criterion, the allowable number of shipments per year is calculated. The resulting number of shipments allowed is eight per year. Therefore, the shipment campaign for up to eight shipments per year of the ConcreteShielded RH TRU Drums meets transportation safety requirements.

\subsection{REFERENCES}

HNF-PRO-154, Responsibilities and Procedures for All Hazardous Material Shipments, Fluor Daniel Hanford, Inc., Richland, Washington.

Clarke, R. K, J. T. Foley, W. F. Hartman, and D. W. Lawson, 1976, Severities of Transportation Accidents Volume I/1--Motor Carriers, SLA-74-0001, Sandia Laboratories, Albuquerque, New Mexico.

Green, J. R., B. D. Flanagan, and H. Harris, 1996, Hanford Site Truck Accident Rate, 1990-1995, WHC-SD-TP-RPT-021, Rev. O, Westinghouse Hanford Company, Richland, Washington.

H\&R, 1995, Recommended Onsite Transportation Risk Management Methodology, 522-1, H\&R Technical Associates, Inc., Oak Ridge, Tennessee. 
McCormick, N. J., 1981, Reliability and Risk Analysis: Methods and Nuclear Power Applications, Academic Press, San Diego, California.

Mercado, J. E., 1994, Report on Equivalent Safety for Transportation and Packaging of Radioactive Materia/s, WHC-SD-TP-RPT-001, Rev. O, Westinghouse Hanford Company, Richland, Washington. 


\subsection{APPENDIX: PEER REVIEW CHECKLIST}

\section{CHECKLIST FOR CHECKING OF ANALYSIS/CALCULATIONS}

\begin{tabular}{|c|c|c|c|}
\hline \multicolumn{3}{|c|}{ Document Title: } & \multirow{2}{*}{$\frac{\text { Part B Section 3 Radiological Risk Evaluation }}{\cdots}$} \\
\hline Yes & No & N/A & \\
\hline$[x]$ & {[]} & {$[1$} & Problem completely defined. \\
\hline$[x]$ & {[]} & {[]} & Appropriate analytical method used. \\
\hline$[x]$ & {[]} & {[]} & Necessary assumptions are appropriate and explicitly stated. \\
\hline$[x]$ & 11 & {$[1$} & Computer codes and data files documented: \\
\hline$[x]$ & {[]} & {$[1$} & Data used in calculations explicitly stated in document. \\
\hline$[x]$ & {[]} & [ ] & $\begin{array}{l}\text { Sources of non-standard formula/data are referenced and the correctness of } \\
\text { the reference verified. }\end{array}$ \\
\hline$[x]$ & {[]} & {$[\mathrm{c}$} & Data checked for consistency with original source information as applicable. \\
\hline$[x]$ & {$[1]$} & {$[$ ] } & $\begin{array}{l}\text { Mathematical derivations checked including dimensional consistency of } \\
\text { results. }\end{array}$ \\
\hline$[x]$ & {[]} & {$[1$} & $\begin{array}{l}\text { Models appropriate and used within range of validity or use outside range of } \\
\text { established validity justified. }\end{array}$ \\
\hline$[x]$ & {$[\mathrm{l}$} & {$[1$} & Hand calculations checked for errors. \\
\hline$[x]$ & {$[\mathrm{l}]$} & {$[1]$. } & Code run streams correct and consistent with analysis documentation. \\
\hline$[x]$ & {$[1$} & [1] & $\begin{array}{l}\text { Code output consistent with input and with results reported in analysis } \\
\text { documentation. }\end{array}$ \\
\hline$[x]$ & {[]} & [1] & $\begin{array}{l}\text { Acceptability limits on analytical results applicable and supported. Limits } \\
\text { checked against sources. }\end{array}$ \\
\hline$[x]$ & 11 & [ ] & Safety Margins consistent with good engineering practices. \\
\hline$[x]$ & {$[1$} & {$[1]$} & Conclusions consistent with analytical results and applicable limits. \\
\hline$[x]$ & {[]} & [1] & Results and conclusions address all points required in the problem statement. \\
\hline
\end{tabular}

I have checked the analysis/calculation and it is complete and accurate to the best of my knowledge.

Engineer/Checker Oanet 6 picFolden__Date $3 / 13 / 28$ NOTE: Any hand calculations, notes or summaries generated as part of this check should be signed, dated, and attached to this checklist. Material should be labeled and recorded so that it is intelligible to a technically qualified third party. 
HNF-SD-TP-SEP-051 Rev. 1

\subsection{CONTAINMENT EVALUATION}

\subsection{INTRODUCTION}

This evaluation documents the dose consequence calculations used to support the Transportation Hazard Indicator (THI) evaluation for the Concrete-Shielded RH TRU Drum.

The methodology used in this type of analysis is based on the International Atomic Energy Agency (IAEA) Q-system (IAEA 1990) as outlined in WHC (1993). The IAEA Q-system was developed as an all-encompassing generalized methodology using only the isotope as the defining variable.

There are two receptors considered. The onsite receptor is considered to be $3 \mathrm{~m}$ from the spill for 15 minutes, while the offsite receptor is located at the point of closest public approach to the spill. In the cases where the spill is assumed to take place in controlled areas, the offsite receptor is assumed to be at the Site boundary or the near bank of the Columbia River, whichever is closer. In the cases where the spill is assumed to take place in areas in which access is uncontrolled, the receptor is assumed to be $100 \mathrm{~m}$ away from the spill. The offsite receptor is assumed to inhale the airborne release only.

The source term used in this section is developed in Part B, Section 5.2.

\subsection{RESULTS}

The analysis assumes that $100 \%$ of the inventory of one drum will be released in the accident. Of this a fraction will become airborne (airborne release fraction [ARF]), and a fraction of that will be in the respirable range. Mishima (1993) estimates that for a loss or dislodgment of surface contamination from solids of appreciable mass (e.g., glassware or tools), a free-fall and impaction will result in an ARF of $1 \times 10^{-3}$ with all of that being in the respirable range.

However, for light materials with high surface-to-mass ratios (e.g., paper, cardboard, plastic, or rubber sheeting) very little force would be generated during impact with a surface. For these materials Mishima (1993) postulates that no significant dislodgment of surface contamination would result. On the other hand, a layer of dry contamination lying on a surface on the ground under nominal wind flow conditions has been assigned an aerodynamic release rate of $4 \times 10^{-6} / \mathrm{h}$, which would result in an ARF of $2 \times 10^{-6}$ in the half hour postulated for the accident. All of the contamination released is assumed to be respirable. These numbers are the bounding values culled from the literature. In this analysis, the ARF for the massive solids is used.

Mishima (1993) gives a bounding value of the ARF of $8 \times 10^{\cdot 3}$ for burning to dryness of the nonvolatile elements and $1 \times 10^{-2}$ for cesium. In the absence of particle size distributions, it has been assumed that these are all in the respirable range. Due to the closeness of the release fractions for cesium and the rest of the isotopes, and the fact that cesium's effect on the committed EDE is roughly three orders of magnitude below that of strontium, cesium was assumed to be released identically to the other isotopes.

The AFR of $8 \times 10^{-3}$ was applied to the inventory of a single package, and the resulting source term was evaluated using the GENII and GXO computer codes to estimate the inhalation dose.

Due to the high fissile limits, the potentially dispersible nature of the contents, and the shipment route of the Concrete-Shielded Drum, the scoping analyses show that the inhalation dose 
to the offsite individual will exceed $0.25 \mathrm{SV}(25 \mathrm{Rem})$, so the package is designated as a THI-1 packaging system. This category is the most conservative THI, invoking the most restrictive requirements for quality assurance and risk acceptance criteria. Therefore, no dose consequence analyses are provided in this document.

\subsection{REFERENCES}

IAEA, 1990, Explanatory Material for the IAEA Regulations for the Safe Transport of Radioactive Material, IAEA Safety Series No. 7, 1985 Edition as amended in 1990, International Atomic Energy Agency, Vienna, Austria.

Mishima, J., 1993, Recommended Values and Technical Bases for Airborne Release Fractions (ARFs), Airborne Release Rates (ARRs), and Respirable Fractions (RFs) at DOE Non-Reactor Nuclear Facilities, Draft, DOE-HDBK-0013-93, U.S. Department of Energy, Washington, D.C.

WHC, 1993, Report on Equivalent Safety for Transportation and Packaging of Radioactive Materials, WHC-SD-TP-RPT-001, Rev. O, Westinghouse Hanford Company, Richland, Washington. 


\subsection{SHIELDING EVALUATION}

\subsection{INTRODUCTION}

The Concrete-Shielded RH TRU Drums will be used to transport laboratory waste (e.g., chemwipes, paper towels, rubber gloves, broken glassware) from the 300 Area to the solid waste burial ground in the 200 West Area. The package consists of a container constructed out of an 8-in. schedule 40 steel pipe fitted with a steel top and bottom. This container will be inserted into a 55-gal drum, and the annular space between the container and the drum will be filled with concrete. The isotope distribution that may be used to transport the drums is not limited to the distribution discussed in this section. The source term developed in this section is provided to demonstrate the effect of the original isotope distribution supplied by Pacific Northwest National Laboratory (Pacific Northwest) on shielding when scaled to a limit of $100 \mathrm{~g}$ of fissile material and a surface dose rate on the drum of $1 \mathrm{mSv} / \mathrm{h}(100 \mathrm{mrem} / \mathrm{h})$. See part B, Section 2.2, for the payload restrictions that apply to the amount of fissile material and the overall radionuclide quantity that may be shipped.

\subsection{DIRECT RADIATION SOURCE SPECIFICATION}

The source term used in this section is developed from the original Pacific Northwest National Laboratory data supplied as shown in Section 5.8.2. The data shown in Part B, Section 5.8 .1 , was scaled to an activity of $3.7 \times 10^{10} \mathrm{~Bq}(1 \mathrm{Ci})$ of ${ }^{137} \mathrm{Cs}$, then scaled to produce a surface dose rate of $1 \mathrm{mSv} / \mathrm{h}(100 \mathrm{mrem} / \mathrm{h})$ with $100 \mathrm{~g}$ of fissile material. In this scaling, the alpha-emitting radionuclides were scaled with the fissile isotopes to the $100 \mathrm{~g}$ fissile material limit, and then the remaining beta and gamma emitting isotopes were scaled to produce the surface dose rate of $1 \mathrm{mSv} / \mathrm{h}(100 \mathrm{mrem} / \mathrm{h})$. The resulting source term is shown in Table B5-1 for a single drum. The source term shown in Table B5-1 is NOT authorized for shipment as it exceeds an HRCO due to the activity of the alpha-emitting radionuclides.

\subsubsection{Photon Source}

The photon source (Y-rays and Bremsstrahlung) is computed internally when the ISO-PC computer code (Rittmann 1995) is run for the shielding calculations. The isotopes and their activities are input into the code.

\subsubsection{Beta Source}

Eight of the isotopes in the source are $\beta$-particle emitters. The most energetic of these is the $\beta$-particle emitted by ${ }^{90} \mathrm{Y}$ of $2.27 \mathrm{MeV}$ maximum energy. This particle will travel roughly $1.1 \mathrm{~g} / \mathrm{cm}^{2}$, which is a distance of about $0.5 \mathrm{~cm}$ in concrete. Obviously, none of the $\beta$-particles will escape from the container. The radiative energy loss, converted into Bremsstrahlung, is accounted for by ISO-PC computer code (Rittmann 1995).

\subsubsection{Neutron Source}

The concentration of neutron-emitting radionuclides indicates that the neutron dose is negligible. 
Table B5-1. Source Term for One Drum With $100 \mathrm{~g}$ Fissile Material. (Bq)

\begin{tabular}{|c|c|c|c|c|}
\hline Isotope & $\begin{array}{c}\text { Ratio supplied by } \\
\text { Pacific Northwest } \\
\text { National } \\
\text { Laboratory }\end{array}$ & $\begin{array}{c}\text { Renormalized } \\
\text { inventory with } \\
100 \mathrm{~g} \text { fissile } \\
\text { material }\end{array}$ & $A_{2}(T B q)$ & Fraction of $\mathrm{A}_{2}$ \\
\hline${ }^{235} \mathrm{U}$ & $2.09 \times 10^{3}$ & $3.88 e+05$ & Unlimited & $0.00 e+00$ \\
\hline${ }^{238} \mathrm{U}$ & $1.04 \times 10^{6}$ & $1.93 \mathrm{e}+08$ & Unlimited & $0.00 e+00$ \\
\hline${ }^{238} \mathrm{Pu}$ & $9.10 \times 10^{8}$ & $1.69 \mathrm{e}+11$ & $2 \times 10^{-4}$ & $8.45 e+02$ \\
\hline${ }^{239} \mathrm{Pu}$ & $1.15 \times 10^{9}$ & $2.13 e+11$ & $2 \times 10^{4}$ & $1.07 e+03$ \\
\hline${ }^{240} \mathrm{Pu}$ & $1.14 \times 10^{9}$ & $2.12 \mathrm{e}+11$ & $2 \times 10^{-4}$ & $1.06 e+03$ \\
\hline${ }^{241} \mathrm{Pu}$ & $3.92 \times 10^{10}$ & $7.29 e+12$ & $1 \times 10^{-2}$ & $7.30 \mathrm{e}+02$ \\
\hline${ }^{242} \mathrm{Pu}$ & $4.18 \times 10^{5}$ & $7.75 e+07$ & $2 \times 10^{4}$ & $3.86 e-01$ \\
\hline${ }^{241} \mathrm{Am}$ & $1.12 \times 10^{9}$ & $2.08 \mathrm{e}+11$ & $2 \times 10^{-4}$ & $1.04 \mathrm{e}+03$ \\
\hline${ }^{244} \mathrm{Cm}$ & $9.62 \times 10^{7}$ & $1.79 e+10$ & $4 \times 10^{-4}$ & $4.47 e+01$ \\
\hline${ }^{134} \mathrm{Cs}$ & $4.33 \times 10^{9}$ & $9.25 e+08$ & 0.5 & $1.85 e-3$ \\
\hline${ }^{137} \mathrm{Cs}$ & $3.70 \times 10^{10}$ & $7.92 e+09$ & 0.5 & $1.59 \mathrm{E}-02$ \\
\hline${ }^{137 \mathrm{~m}} \mathrm{Ba}^{*}$ & $3.50 \times 10^{10}$ & $7.47 \mathrm{e}+09$ & NA & NA \\
\hline${ }^{90} \mathrm{Sr}$ & $1.42 \times 10^{10}$ & $3.03 e+09$ & 0.1 & $3.04 \mathrm{E}-02$ \\
\hline $90 y^{*}$ & $1.42 \times 10^{10}$ & $3.03 e+09$ & NA & NA \\
\hline${ }^{54} \mathrm{Mn}$ & $8.99 \times 10^{8}$ & $1.92 e+08$ & 1 & 1.92E-04 \\
\hline${ }^{60} \mathrm{Co}$ & $7.70 \times 10^{8}$ & $1.65 e+08$ & 0.4 & 4.13E-04 \\
\hline${ }^{125} \mathrm{Sb}$ & $2.01 \times 10^{9}$ & $4.29 e+08$ & 0.9 & 4.77E-04 \\
\hline${ }^{154} \mathrm{Eu}$ & $3.53 \times 10^{9}$ & $7.55 e+08$ & 0.5 & 1.51E-03 \\
\hline Total & $1.55 \times 10^{11}$ & $8.13 E 12$ & & $4790^{*}$ \\
\hline
\end{tabular}

NOTE: This source term exceeds a highway route controlled quantity

(49 CFR 173.403) and is NOT authorized for shipment with the radionuclide distribution shown. This distribution is only to be used for shielding and dose consequence evaluation purposes. The shipper must limit the material quantity to that discussed in Part B, Section 2.2.

* Daughter product.

49 CFR 173, "Shippers--General Requirements for Shipments and Packagings," Code of Federal Regulations, as amended.

Pacific Northwest $=$ Pacific Northwest National Laboratory.

\subsection{SUMMARY OF SHIELDING PROPERTIES OF MATERIALS}

The source is made up of steel paint cans filled with laboratory waste (chem-wipes, paper towels, rubber gloves, broken glass, etc.). Up to approximately six of these paint cans are placed in a steel container consisting of a 56.6 - $\mathrm{cm}$-long section of 8 -in. schedule 40 pipe. A steel bottom is added, and a 10 -in. to 8 -in. schedule 40 pipe reducer is welded to the top. In the tapered section of the reducer is fitted a steel plug. The source density is calculated by dividing the assumed weight of the source (gross weight $=2.27 \times 10^{3} \mathrm{~g} / \mathrm{can}$ and net weight $=1.81 \times 10^{3}$ $\mathrm{g} / \mathrm{can}$ ) by the volume of the container. 
This container is then placed inside a 55-gal steel drum, and the annular space between the container and the drum is filled with concrete of density equal to $2.31 \mathrm{~g} / \mathrm{cm}^{3}$.

\subsection{NORMAL. TRANSFER CONDITIONS}

\subsubsection{Conditions To Be Evaluated}

Dose rates are evaluated on the drum surface only. Due to the variability of the loading scheme and possible payloads, the shipper must ensure that all other transportation limits shown below are met.

\subsubsection{Acceptance Criteria}

The surface dose rate of a single drum is limited to $1 \mathrm{mSv} / \mathrm{h}(100 \mathrm{mrem} / \mathrm{h})$. The dose rate measured at the vertical planes projected from the outer edges of the vehicle are limited to $2 \mathrm{mSv} / \mathrm{h}$ $(200 \mathrm{mrem} / \mathrm{h})$, and the dose rate at any point $2 \mathrm{~m}$ from the vehicle edge is limited to $0.1 \mathrm{mSv} / \mathrm{h}$ $(10 \mathrm{mrem} / \mathrm{h})$. A maximum dose rate of $0.02 \mathrm{mSv} / \mathrm{h}(2 \mathrm{mrem} / \mathrm{h})$ for a nonradiation worker or $0.05 \mathrm{mSv} / \mathrm{h}(5 \mathrm{mrem} / \mathrm{h})$ for a radiation worker is allowed in any normally occupied space in the vehicle.

The drum surface dose rate limit is determined by the acceptance criteria for storage and disposal. The other limits are based on the exclusive use limits in 49 CFR 173.441 although the flatbed truck used for the shipment will not be an enclosed vehicle. The dose rate measured at the surface of any drum, at the vertical planes projected from the outer edges of the vehicle, and to the driver cannot be exceeded.

\subsubsection{Shielding Calculations}

The computer code ISO-PC (Rittman 1995) was used for the shielding calculations. The input file is shown in Section 5.8.1. This code performs a point kernel integration over the source region and sums the contributions of each of the point kernels to the dose at a point detector. The program also accounts for Bremsstrahlung produced by $\beta$-particles. The fluence-to-dose conversion factors used in the calculation were the anterior-to-posterior irradiation pattern as presented in ANSI/ANS-6.1.1 (ANSI/ANS 1991).

The code was used in an iterative fashion. First, the original radioisotope distribution shown in Part B, Section 5.8.2, was used with the alpha-emitting isotopes scaled to a total fissile material content of $100 \mathrm{~g}$. This produced a dose rate on the surface of the drum of $4.7 \mathrm{mSv} / \mathrm{h}$ $(467 \mathrm{mrem} / \mathrm{h})$. For the final run the gamma- and beta-emitting isotopes were scaled down by a factor of 4.67 and shown to produce a surface dose rate of $1 \mathrm{mSv} / \mathrm{h}(100 \mathrm{mrem})$. The final results were used to produce the radioisotope distribution shown in Table B5-1. Note that the surface dose rates were calculated on the side of the drum because the dose rates on the top and bottom are considerably lower due to the steel in the top and bottom of the inner liner.

\subsection{ACCIDENT CONDITIONS}

With the top of the inner steel enclosure bolted down with 12 bolts and the concrete enclosed between two steel enclosures, the probable accident envisioned is that the lid of the 55 gal drum is removed by the force of the accident. 
The top of the drum is 16-gauge steel. The computer code 1SO-PC (Rittman 1995) was run with and without this thickness of steel removed from the top shield. Under the condition of the removal of the top, the dose rate at a distance of $1 \mathrm{~m}$ from the top of one drum is $0.015 \mathrm{mSv} / \mathrm{h}$ $(1.5 \mathrm{mrem} / \mathrm{h})$. This dose rate is below the $49 \mathrm{CFR} 173$ limit for accidents of $0.01 \mathrm{~Sv} / \mathrm{h}(1 \mathrm{rem} / \mathrm{h})$ at $1 \mathrm{~m}$.

\subsection{SHIELDING EVALUATION AND CONCLUSIONS}

The gamma-emitting isotopes in the source term were scaled to achieve a surface dose rate of $1 \mathrm{mSv} / \mathrm{h}(100 \mathrm{mrem} / \mathrm{h})$ on the surface of the drum with the alpha emitting-isotopes scaled to $100 \mathrm{~g}$ of fissile material. An accident, postulated to result in loss of the drum lid, was evaluated and shown to be well within the accident dose rate limit criteria. Although in practice, the isotope distribution is not fixed, the maximum allowed surface dose rate is limited to $1 \mathrm{mSv} / \mathrm{h}$ $(100 \mathrm{mrem} / \mathrm{h})$, so the change in dose rate from the postulated accident will not differ from that shown above. Due to the variability of the loading scheme and isotope distribution in the payloads, the shipper must ensure that all transportation dose rate limits and material quantity limits are met as shown in Part B, Section 1.2.

\subsection{REFERENCES}

49 CFR 173, "Shippers-General Requirements for Shipments and Packagings," Code of Federal Regulations, as amended.

ANSI/ANS, 1991, Neutron and Gamma-ray Fluence-to-dose Factors, ANSI/ANS-6.1.1, American National Standards Institute/American Nuclear Society, New York, New York.

Rittman, P. D., 1995, ISO-PC Version 1.98 - User's Guide, WHC-SD-WM-UM-030, Rev. O, Westinghouse Hanford Company, Richland, Washington.

\subsection{APPENDICES}

\subsubsection{ISO-PC Input File}

$0 \quad 2$ CONCRETE LINED WASTE PACKAGE ASSEMBLY

DOSE FROM ONE DRUM SIDE $100 \mathrm{~g}$ Fissile

\&INPUT NEXT $=1$, IGEOM $=7, \mathrm{NSHLD}=4, \mathrm{JBUF}=3, \mathrm{PPRNT}=0$,

$X=29 ., T(1)=10.14, T(2)=0.82, T(3)=17.62, T(4)=0.15$,

$\mathrm{SLTH}=69.62, Y=34.81, \mathrm{DUNIT}=1, \mathrm{OPTION}=0$,

$\mathrm{NPSI}=30, \mathrm{NTHETA}=30$,

WEIGHT $(476)=1.05 \mathrm{E}-05$.

WEIGHT $(526)=5.23 \mathrm{E}-03$,

WEIGHT(492) $=4.57 E+00$

WEIGHT(493) $=5.77 \mathrm{E}+00$.

WEIGHT(494) $=5.73 \mathrm{E}+00$,

WEIGHT(495) $=1.97 E+02$,

WEIGHT(497) $=2.09 E-03$,

WEIGHT $(496)=5.63 E+00$,

WE $\mid \mathrm{GHT}(500)=4.83 \mathrm{E}-01$,

WE $\mid \mathrm{GHT}(319)=2.50 \mathrm{E}-02$,

WEIGHT $(335)=2.14 \mathrm{E}-01$,

WEIGHT $(336)=2.02 E-01$,

WEIGHT ( 82) $=8.20 \mathrm{E}-02$,

WEIGHT ( 84) $=$ 8.20E-O2,

WEIGHT(465) $=5.19 \mathrm{E}-03$,

WEIGHT(472) $=$ 4.46E-03, 


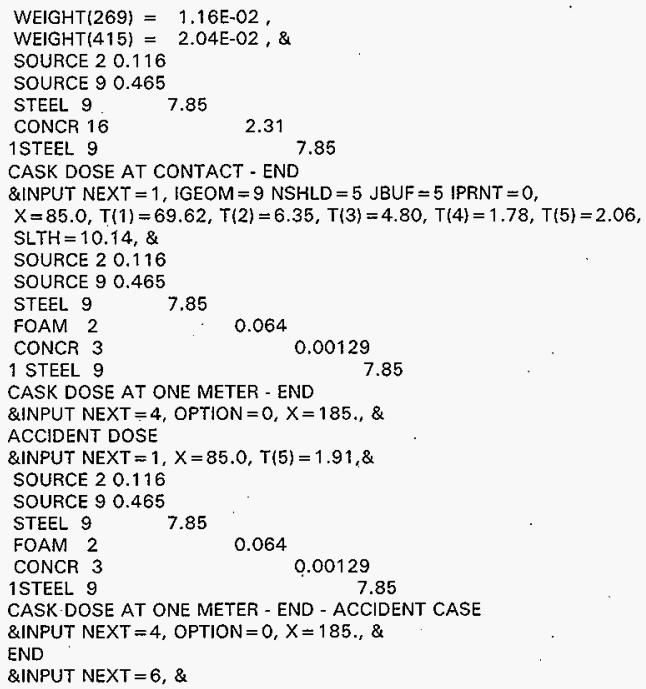




\subsubsection{Source Term Ratio Documentation}

\section{Pacific Northwest National Laboratory}

Operates by-Battelle for the U.S. Department of Energy

August 23, 1996

J. G. Field

Westinghouse Hanford Co.

P. O. Box 1970

Richland, WA 99352

Dear, Mr. Field,

The source term information pertinent to the design of the RH-TRU ConcreteLined Drum System is attached. This information is being transmitted to you for inclusion in the Safety Evaluation for Packing (SEP) which is being prepared by Dave Clem et al for PNNL. If any additional information is required. please contact me at the number below or Jeff Huisingh at. 376-6226.

Thank you.

Sincerely,

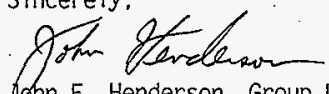

Lohn F. Henderson, Group Leader

Postirradiation Testing Laboratory

cc: DK Clem, WHC

JR Green. WhC

CC: JD Huisingh, ICF-K

JE Mercado.WHC

CC: JM Seay, PNNL

RW Stevens. PNNL

JFH: $3 \mathrm{mr}$

Attachment 
HNF-SD-TP-SEP-051 ReV. 1

\section{Pacific Northwest National Laboratory}

Operated by Battenle for the U.S. Depariment of Energy

SOURCE TERM DATA FOR 327 BUILDING RH-TRU WASTE SHIPMENTS

\begin{tabular}{|l|l|l|l|l|}
\hline Nuc7ide & & Curies & & \\
\hline U235 & $5.66 \mathrm{E}-8$ & & \\
\hline U238 & $2.82 \mathrm{E}-5$ & & \\
\hline Pu238 & $2.46 \mathrm{E}-2$ & & \\
\hline Pu239 & $3.10 \mathrm{E}-2$ & & \\
\hline Pu240 & & $3.08 \mathrm{E}-2$ & & \\
\hline Pu241 & $1.06 \mathrm{E}-0$ & & \\
\hline Pu242 & & $1.13 \mathrm{E}-5$ & & \\
\hline Am241 & & $3.04 \mathrm{E}-2$ & & \\
\hline Cm244 & & $2.60 \mathrm{E}-3$ & & \\
\hline Cs134 & & $1.17 \mathrm{E}-1$ & & \\
\hline Cs137 & & $1.00 \mathrm{E}+0$ & & \\
\hline Sr90* & & $3.83 \mathrm{E}-1$ & & \\
\hline Mn54 & & $2.43 \mathrm{E}-2$ & & \\
\hline Co60 & & $2.08 \mathrm{E}-2$ & & \\
\hline Sb125 & & $5.42 \mathrm{E}-2$ & & \\
\hline Eu154 & & $9.53 \mathrm{E}-2$ & & \\
\hline Tota1 & & 2.874 & & \\
\hline & & & & \\
\hline & & & & \\
\hline
\end{tabular}




\subsubsection{Peer Review Checklist}

\section{CHECKLIST FOR CHECKING OF ANALYSIS/CALCULATIONS}

\begin{tabular}{|c|c|c|c|}
\hline \multicolumn{3}{|c|}{ Document Title: } & Section 5 Shielding Evaluation \\
\hline Yes & No & N/A & $\cdots$ \\
\hline$[x]$ & {[]} & {$[1$} & Problem completely defined. \\
\hline$[x]$ & {[]} & [1] & Appropriate analytical method used. \\
\hline$[x]$ & {[]} & {[]} & Necessary assumptions are appropriate and explicitly stated. \\
\hline$[x]$ & {[]} & {$[1$} & Computer codes and data files documented: \\
\hline$[x]$ & {$[1$} & {$[1]$} & Data used in calculations explicitly stated in document. \\
\hline$[x]$ & [ ] & {$[1$.} & $\begin{array}{l}\text { Sources of non-standard formula/data are referenced and the correctness of } \\
\text { the reference verified. }\end{array}$ \\
\hline$[x]$ & {[]} & {$[1$.} & Data checked for consistency with original source information as applicable. \\
\hline$[x]$ & {[]} & {[]} & $\begin{array}{l}\text { Mathematical derivations checked including dimensional consistency of } \\
\text { results. }\end{array}$ \\
\hline$[x]$ & {[]} & {$[1$} & $\begin{array}{l}\text { Models appropriate and used within range of validity or use outside range of } \\
\text { established validity justified. }\end{array}$ \\
\hline$[x]$ & {$[1$} & {[]} & Hand calculations checked for errors. \\
\hline$[x]$ & 11 & [ ] & Code run streams correct and consistent with analysis documentation. \\
\hline$[x]$ & [ ] & {$[1]$} & $\begin{array}{l}\text { Code output consistent with input and with results reported in analysis } \\
\text { documentation. }\end{array}$ \\
\hline$[x]$ & {[]} & {[]} & $\begin{array}{l}\text { Acceptability limits on analytical results applicable and supported. Limits } \\
\text { checked against sources. }\end{array}$ \\
\hline$[x]$ & [ ] & [I] & Safety Margins consistent with good engineering practices. \\
\hline$[x]$ & {$[1$} & {[]} & Conclusions consistent with analytical results and applicable limits. \\
\hline$[x]$ & [ ] & {[]} & Results and conclusions address all points required in the problem statement. \\
\hline
\end{tabular}

I have checked the analysis/calculation and if is complete and accurate to the best of my knowledge.

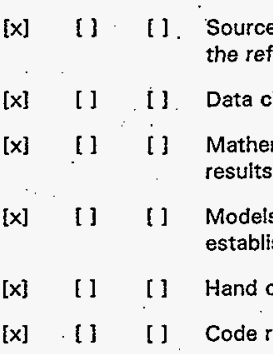

HNF-SD-TP-SEP-OST ReV. 1

-




\subsection{CRITICALITY EVALUATION}

The maximum amount of fissile material allowed in a concrete-shielded drum is $100 \mathrm{~g}$. The amount of fissile material has been shown to be far below the minimum critical mass of $370 \mathrm{~g}$ of ${ }^{239} \mathrm{Pu}$ under the most ideal conditions in organic material (polyethylene) (ANS 1977). Since the fissile material distribution, the waste matrix material, or the specific ratio of hydrogen nuclei to fissile material nuclei $(H / X)$ for the material to be shipped is not known, it is necessary to limit the total amount of fissile material in a shipment of concrete-lined drums to $300 \mathrm{~g}$ (three $100 \mathrm{~g}$ drums) if any drum in a shipment has more than $15 \mathrm{~g}$ of fissile material. This is without regard to the specific fissile isotope distribution.

However, if all the drums in a shipment contain $15 \mathrm{~g}$ or less fissile material, the number of drums is not limited as this is a fissile excepted quantity (49 CFR 173.453). This is provided that all other requirements of Part $B$, Section 2.2, are met.

\subsection{REFERENCES}

49 CFR 173, "Shippers--General Requirements for Shipments and Packagings," Code of Federal Regulations, as amended.

ANS, 1977, Transactions of the American Nuclear Society, 1977, Volume 77, P 419, L.C. Davenport and J.K. Thompson, "A Survey of Criticality Parameters for ${ }^{239} \mathrm{Pu}$ in Organic Media." 
HNF-SD-TP-SEP-051 Rev. 1

This page intentionally left blank. 


\subsection{STRUCTURAL EVALUATION}

The Concrete-Shielded RH TRU Drum packaging is essentially a carbon steel pipe encased in concrete and housed in a 55-gal drum. It was designed to transport contaminated waste from the 327 Building to the Transuranic Waste Storage and Assay Facility for storage. The contents of the package are contaminated hot cell wastes, which have been put into paint cans.

\subsection{STRUCTURAL DESIGN AND FEATURES}

The outer shell of the package is a UN1A2 55-gal galvanized drum with a removable gasketed head cover and bolted locking ring. The drum and head cover are manufactured from 18gage American Society for Testing and Materials (ASTM) A 366 (ASTM 1989) galvanized steel. A NucFil $1-013$ filter is provided on the head cover. Containing the contents within the drum is an inner shell consisting of a schedule 40 pipe with flanged ends encased in concrete. The inner shell is a pipe manufactured from 8 -in. schedule 40 carbon steel pipe with a 10 -in. $x$-in. schedule 40 concentric reducer welded to the top end. The reducer is welded to a $45.09-\mathrm{cm}-(16.75-\mathrm{in} .-)$ outside diameter by $3.8-\mathrm{cm}-(1.5$-in.-) thick circular flange, equipped with $12,1 / 2-$ in. 13 UNC bolt holes. Closure is provided by $45.09-\mathrm{cm}-(16.75$-in.- $)$ outside diameter by $1.91-\mathrm{cm}$ - $(3 / 4-\mathrm{in} .-)$ thick cover plate attached to the inner shell with $12,1 / 2$-in. 13 UNC ASTM A-449 (ASTM 1989) closure bolts. The cover plate is also provided with a NucFil-13 filter. Compressed by the closure bolts between the cover plate and inner shell assembly is a $0.32+\mathrm{cm}-(1 / \%-i n .-)$ thick silicone rubber gasket. Installed inside the inner shell is a $6.4-\mathrm{cm}\left(2 \frac{1}{2}-\mathrm{in}\right.$.) cone-shaped shield plug fabricated from ASTM A-36 (ASTM 1989) carbon steel: Between the inner shell and the cover plate is a rigid, close-cell polyurethane foam with a density of approximately $64.07 \mathrm{~kg} / \mathrm{m}^{3}\left(4 \mathrm{lb} / \mathrm{ft}^{3}\right)$. Bottom end closure is provided by a $34.59-\mathrm{cm}-(13.62-\mathrm{in}$.- $)$ diameter $6.4-\mathrm{cm}-\left(2 \frac{1}{2}-\mathrm{in} .-\right)$ thick plate, which is welded to the inner shell. Welded to the bottom plate are $0.64-\mathrm{cm}-(1 / 4-\mathrm{in} .-)$ thick outriggers for embedment into the concrete. Inner shell welds are performed in accordance with AWS/ANSI D1.1 (AWS/ANSI 1989). The specification and physical properties for the materials of construction are shown in Table B7-1.

The properties of the concrete are specified as having a density of 2,307 to $2643 \mathrm{~kg} / \mathrm{m}^{3}$ (144 to $\left.165 \mathrm{lb} / \mathrm{ft}^{3}\right)$ with minimum strength of $21 \mathrm{MPa}(3,000 \mathrm{psi})$ at 28 days.

\subsection{CHEMICAL. AND GALVANIC REACTIONS}

The UN1A2 55-gal drum is manufactured from galvanized steel, which inhibits normal atmospheric corrosion for transportation. The carbon steel lid and hub flange are protected by the drum from direct exposure to the atmosphere for transportation. For those carbon steel components encased in concrete, the alkaline nature of concrete ensures permanence of the steel. This has been confirmed by the examination of steel reinforcement in buildings that have been demolished (Baumeister and Marks 1967).

\footnotetext{
$1_{\text {NucFil is a trademark of NFT Incorporated. }}$
} 
Table B7-1. Structural Materials of Construction at $93.3^{\circ} \mathrm{C}\left(200^{\circ} \mathrm{F}\right)$.

\begin{tabular}{|l|l|l|l|l|}
\hline \multicolumn{1}{|c|}{ Item(s) } & \multicolumn{1}{|c|}{ Specification } & \multicolumn{1}{|c|}{$\begin{array}{c}\text { Ultimate strength } \\
\mathrm{MPa}(\mathrm{ksi})\end{array}$} & $\begin{array}{c}\text { Yield strength } \\
\mathrm{MPa}(\mathrm{ksi})\end{array}$ & $\begin{array}{c}\text { Allowable stress } \\
\mathrm{MPa}(\mathrm{ksi})\end{array}$ \\
\hline $\begin{array}{l}\text { Cover plate, hub flange, } \\
\text { bottom end plate }\end{array}$ & ASTM A-516 Grade 60 & $414(60)$ & $221(32)$ & $103(15)$ \\
\hline Closure bolts & ASTM A-449 & $827(120)$ & $634(92)$ & $421(61)$ \\
\hline Concentric reducer & ASTM A-234 Grade & $414(60)$ & $241(35)$ & $103(15)$ \\
\hline W-in. schedule 40 pipe & ASTM A-106 Grade B & $414(60)$ & $241(35)$ & $103(15)$ \\
\hline
\end{tabular}

Source for all material properties: ASME, 1995, ASME Boiler and Pressure Vessel Code, Section II, Part D, American Society for Mechanical Engineers, New York, New York.

\subsection{BRITTLE FRACTURE}

Based on the requirements for low-temperature operations established in ASME (1995c) Section VIII, Division 1, critical packaging materials are acceptable for a minimum operating temperature of $-12.2^{\circ} \mathrm{C}\left(10^{\circ} \mathrm{F}\right)$ without impact testing. The 55 -gal drum, 8-in. schedule 40 pipe, and concentric reducer have thicknesses less than $1 \mathrm{~cm}(0.4 \mathrm{in}$.$) thickness. Consequently these$ materials have a minimum operating temperature of less than $-12.2^{\circ} \mathrm{C}\left(10^{\circ} \mathrm{F}\right)$. The heavy cover plate, hub flange, and bottom end flange are fabricated from normalized ASTM A-516 carbon steel and are under $10 \mathrm{~cm}(4 \mathrm{in}$.) in thickness. These components also have a minimum operating temperature of less than $-12.2^{\circ} \mathrm{C}\left(10^{\circ} \mathrm{F}\right)$. The closure bolts are manufactured from ASTM A-449 (ASTM 1989) carbon steel and have a low temperature limit of $-29^{\circ} \mathrm{C}\left(-20^{\circ} \mathrm{F}\right)$. This demonstrates the package materials are acceptable for transport for temperatures above $-12.2{ }^{\circ} \mathrm{C}\left(10^{\circ} \mathrm{F}\right)$.

\subsection{SIZE OF PACKAGE AND CAVITY}

The interior dimensions of the package are for a UN1A2 55-gal drum. The interior cavity dimensions for a $55-\mathrm{gal}$ drum are for a right circular cylinder with a height of $86.1 \mathrm{~cm}(33.9 \mathrm{in}$.) and a diameter of $57.15 \mathrm{~cm}(22.50 \mathrm{in})$ : The inner shell assembly cavity is also a right circular cylinder. Clear dimensions of the cavity are $63.22 \mathrm{~cm}(24.89 \mathrm{in.})$ in height and $20.27 \mathrm{~cm}(7.98 \mathrm{in}$. diameter.

\subsection{WEIGHT AND CENTER OF GRAVITY}

The maximum gross weight of the package is limited to $658 \mathrm{~kg}(1,450 \mathrm{lb})$. Estimated empty weight of the package is $619 \mathrm{~kg}(1,364 \mathrm{lb})$. The center of gravity is located at approximately the geometric center of the package.

\subsection{TAMPER-INDICATING FEATURES}

There are no tamper-indicating features provided on this package. 


\subsection{POSITIVE ClosuRE}

Positive closure of the package is provided by $12, \frac{1}{2}$-in. 13 UNC hex head bolts on the cover plate and threaded into the inner shell assembly. An additional positive closure is provided by a bolted lock ring securing the lid onto the UN1A2 55-gal drum.

\subsection{LIFTING AND TIEDOWN DEVICES}

There are two stainless steel wire rope assemblies welded to the shield plug for lifting and handling of the shield plug. Each stainless steel wire rope has a rated capacity of $798 \mathrm{~kg}(1,760$ Jb). The McMaster-Carr SAFE-LINE (McMaster-Carr 1990) rope clips have a rated capacity of $90 \%$ of the wire rope capacity. The estimated weight of the shield plug is $23 \mathrm{~kg} \mathrm{(50} \mathrm{lb).} \mathrm{Consequently,}$ there is a large margin of safety for lifting and handling of the shield plug. No other lifting devices are provided on the package. There are no tiedown devices provided on the package.

\subsection{NORMAL CONDITIONS OF TRANSPORT (NCT)}

\subsubsection{Conditions To Be Evaluated}

The analytical NCT tests to be applied for this package are a $1.2-\mathrm{m}(4.0-\mathrm{ft})$ flat top end drop onto a concrete surface and an external pressure reduction of $24.1 \mathrm{kPa}(3.5 \mathrm{psia}$ ). Loadings from these two conditions are combined for determination of package performance. For conservatism, the NCT operating temperature of the package is assumed at $93.3^{\circ} \mathrm{C}\left(200^{\circ} \mathrm{F}\right)$. Due to the thickness of the inner shell and concrete, the package is not vulnerable to NCT penetration. Vibration performance of the package is not assessed since each package is for one-time transport.

\subsubsection{Acceptance Criteria}

Acceptance of the performance of the package design is based on the stresses induced by the loading remaining below the material specified allowable stresses. The allowable stresses are based on the stress intensity method for failure determination used by ASME in Section III, Subsection NB, for Service Level A conditions (ASME 1995b). Maintaining the contents within the package for the NCT evaluated is demonstrated by the stress intensities resulting from the applied loads remaining below the allowables.

\subsubsection{Structural Model}

The structural evaluation of this package is based on classical linear elastic analytical methods and techniques. Determination of impact loads are based on the pressure flow concept set forth by Oak Ridge National Laboratory (ORNL 1970). Within the evaluation only the critical components for maintaining the contents in the package are evaluated. The evaluated critical components for this package are defined as the cover plate and closure bolts.

\subsection{STRUCTURAL EVALUATION AND CONCLUSIONS}

Based on the Oak Ridge National Laboratory pressure flow concept of steel (ORNL 1970), the impact deceleration load factor for a 1.2-m (4.0-ft) flat top end drop onto a concrete surface was determined as $78 \mathrm{~g}$. As shown in Part B, Section 5.13, the deceleration load factor is a result of the 
deformation of the 55-gal drum and lid upon impact. This deceleration load factor multiplied by the weight of the cover plate is then applied as a uniform load on the upper closure system, which consists of the cover plate and hold-down bolts. An additional deceleration load factor is determined for the impact of the contents onto the cover plate. Determination of the deceleration load factor of the contents is based on deformation of the foam insert inside the inner shell. In this case the static crush stress and strain of the foam are used to determine the deceleration load factor. This factor times the weight of the contents is then applied as a uniform load on the upper closure system. These two loads are combined with the differential pressure load to determine the stresses on the closure bolts and cover plate.

The stress in the bolts are evaluated by the methods outlined in Stress Analysis of Closure Bolts for Shipping Casks (LLNL 1993). Results of the evaluation show the margins of safety for the average stress is 1.54 , average shear stress is 3.99 , and total stress is 1.11 . Stresses on the cover plate are evaluated based on idealizing the plate as a simply supported circular plate under uniform loading. The maximum total stress on the plate occurs at the center of the plate. Based on the ASME allowable for ASTM A-516 (ASTM 1989) carbon steel, the margin of safety for total stress is 3.38. These large positive margins of safety demonstrate that the cover plate and closure bolts have sufficient structural integrity to maintain the contents in the package during NCT.

\subsection{ACCIDENT FAILURE THRESHOLDS}

The failure thresholds are the conditions at which the package fails to retain the contents. These parameters are used as inputs in developing the transportation risk assessment. Failure determination is based on exceeding ASME Section III, Subsection NB, allowables for Service Level $D$ conditions (ASME 1995b). In Part B, Section 7.13, the failure thresholds for impact velocity change and puncture are determined. For this package based on the NCT drop evaluation, loading from a $1.2-\mathrm{m}(4.0-\mathrm{ft})$ drop exceeds the 71,170 -newton $(16,000-\mathrm{lb})$ crush load failure threshold load for a small package. Consequently, it demonstrated that the package will not crush. In the evaluation in Part B, Section 7.13 , the impact velocity change failure threshold is $37 \mathrm{~km} / \mathrm{h}$ ( $23 \mathrm{mph}$ ) for the package. This failure threshold is based on the orientation that causes the most damage. In this case, an oblique, over-the-center-of-gravity impact of the package causes the maximum damage to the packaging. The puncture failure threshold is based on the Sandia National Laboratory methodology (SNL 1976), which equates the ratio relative velocity of the package to a probe of a given diameter. For this package the puncture failure threshold is $265 \mathrm{sec}^{-1}$.

\subsection{REFERENCES}

ASME, 1995a, ASME Boiler and Pressure Vessel Code, Section II, Part D. American Society of Mechanical Engineers, New York, New York.

ASME, 1995b, ASME Boiler and Pressure Vessel Code, Section III, Subsection NB, American Society of Mechanical Engineers, New York, New York, 1995.

ASME, 1995c, ASME Boiler and Pressure Vessel Code, Section VIII, Dívision 1, American Society of Mechanical Engineers, New York, New York.

AWS/ANSI, 1989, Structural Welding Code-Steel, AWS/ANSI D1.1-89, American Welding Society/American National Standards Institute, Miami, Florida.

ASTM, 1989, Annual Book of ASTM Standards, Vol. 1.01 and 1.04, American Society of Testing, Philadelphia, Pennsylvania. 
Baumeister, T., and L. S. Marks, 1967, Standard Handbook for Mechanical Engineers, Seventh Edition, McGraw-Hill Book Company, New York, New York.

LLNL, 1993, Stress Analysis of Closure Bolts for Shipping Casks, NUREG/CR-6007, TI 006540, Lawrence Livermore National Laboratory, Livermore, California.

McMaster-Carr, 1990, Catalog 90, McMaster-Carr Supply Company, Los Angeles, California.

ORNL, 1970, Cask Designer's Guide, ORNL-NISC-68, Oak Ridge National Laboratory, Oak Ridge, Tennessee.

SNL, 1976, Severities of Transportation Accidents, Volume 1: Summary, SLA-74-0001, Sandia National Laboratory, Albuquerque, New Mexico. 
HNF-SD-TP-SEP-051 Rev. 1

\subsection{APPENDICES}

\subsubsection{Engineering Safety Evaluation--Failure Thresholds}

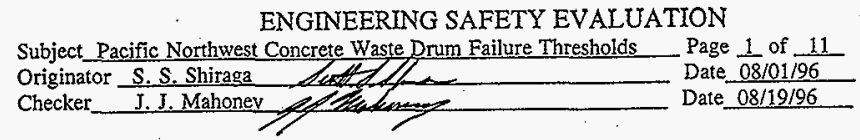

I. Objective:

The objective of this evaluation is to determine the Pacific Northwest Concrete Waste Drum inpact velocity change and puncture failure thresholds.

II. References:

ASME, 1992, Boiler and Pressure Vessel Code, Section III, Service Level D, American Society of Mechanical Engineers, New York, New York.

ASME, 1992, Boiler and Pressure Vessel Code, Section VIII, American Society of Mechanical Engineers, New York, New York.

ASME, 1995, Boiler and Pressure Vessel Code, Section II, American Society of Mechanical Engineers, New York, New York.

DOD, 1994, Military Handbook - Metallic Materials and Elements for Aerospace. Vehicle Structures, MIL-HDBK-5G, U.S. Department of Defense, Washington, D.C., November 1994.

General Plastics, 1996, LAST-A-FOAM FR-6700 Product Data Sheet, General Plastics, Tacoma, Washington, June 1996.

LINL, 1993, Stress Analysis of Closure Bolts for Shipping Casks, NUREG/CR-6007, TI 006540, Lawrence Livermore National Laboratory, Livermore, California, January 1993.

ORNL, 1970, Cask Designer's Guide, ORNL-NISC-68, Oak Ridge National Laboratory, Oak Ridge, Tennessee, February 1970.

Pacific Northwest, 1996, Concrete-Lined Waste Package, drawing H-3-304541, Rev. 0, Pacific Northwest National Laboratory, Richland, Washington, July 1996.

SNL, 1976, Severities of Transporation Accidents, Volume 1: Summary, Sandia National Laboratory, Albuquerque, New Mexico, July 1976.

III. Results and Conclusions:

For this evaluation, the package velocity impact failure threshold is the impacting velocity at which the lid bolts fail and the contents are expelled from the package. The deceleration loading from the impact onto a concrete surface is determined by the pressure flow concept developed by ORNL

(ORNL 1970) in the worst case orientation. However, since the outer packaging is sheet metal, the concrete acts as a hard unyielding surface. Package failure parameters are determined by classical methods. For conservatism, the NCT loading from pressure is combined with the drop loading. The puncture failure threshold is determined by the methods developed by SNL (SNL 1976), which is determined by the ratio of relative velocity of a package to a probe. 


\section{ENGINEERING SAFETY EVALUATION}

Subject Pacific. Northwest Concrete Waste Drum Failure Thresholds

Originator S.S. Shiraga

Checker J.J. Mahoney

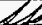

Page 2 of 11

Date $08 / 01 / 96$

tex

Date $08 / 19 / 96$.

Results of the evaluation show the package closure lid bolts fail at an impact velocity of $23 \mathrm{mph}$. The ratio of the relative velocity of the package to a probe is determined as $265 \mathrm{sec}^{-1}$. 
ENGINEERING SAFETY EVALUATION

Subject Pacific Northwest Concrete Waste Drum Failure Thresholds

Originator S. S. Shiraga

Page 3 of 11

Checker J. J. Mahoney

tac

Date $08 / 01 / 96$

Date $08 / 19 / 96$

\section{Evaluation:}

\section{Failure Threshold Evaluation of Pacific Northwest Drum Design}

Dimensional values from Pacific Northwest Drawing H-3-304541 (Pacific Northwest 1996):

Assumed drum thickness: $\quad t_{d}=0.0516$ in.

Lid thickness: $t_{1}=0.0516$ in

Drum ID: $\quad \mathrm{id}_{d}=22.5 \mathrm{in}$.

Lid total depth: $\quad \mathrm{d}_{\mathrm{id}}=0.75 \mathrm{in}$.

Corner radius: $r_{c o r}:=0.25$ in.

Density of stainless steel:

$$
P_{\text {sst }}=0.29 \frac{\mathrm{lb}}{\mathrm{in}^{3}}
$$

Flow stress of drum material: $\sigma_{\mathrm{fs}}=50,000 \mathrm{psi}$

Assumed initial crush height: $h_{\mathrm{crc}}=\mathrm{d}_{\mathrm{ifd}}-2 \mathrm{r}_{\mathrm{cox}}$

Outside diameter of drum: $\quad \mathrm{od}_{\mathrm{d}}=\mathrm{jd}_{\mathrm{d}}+2 \mathrm{t}_{\mathrm{d}}$

ID of lid: $\quad \mathrm{id}_{1}=o d_{d}-2 t_{d}-2 t_{1}$

Gross weight of drum: $\mathrm{W}_{\mathrm{dr}}=1,450 \mathrm{lb}$

Assume drop height: $h_{\text {crop }}=17 \mathrm{ft}$

Weight determination:

$$
\text { Lid dimensions: } \quad t_{p l}=0.75 \mathrm{in.} \quad \text { Diameter: } \quad a_{1 / 4}=16.75 \mathrm{in.}
$$

Lid weight: $\quad \mathrm{W}_{\mathrm{lid}}=\rho_{\mathrm{sst}}=\frac{\pi \mathrm{d}_{\mathrm{lid}}{ }^{2}}{4} \mathrm{t}_{\mathrm{pt}} \quad \mathrm{W}_{\mathrm{lid}}=48 \mathrm{lb}$

Weight of contents: $\quad \mathrm{W}_{\mathrm{com}}=36 \mathrm{lb}$

Plug dimensions: $\quad b d_{\text {phg }}=10.05$ in. $\quad \cdots s d_{\text {pug }}=8.25$ in.

$$
\mathrm{t}_{\text {tand }}=0.5 \mathrm{in.} \quad \mathrm{h}_{\mathrm{plug}}=2.5 \mathrm{in.}
$$

Volume of plug, plate, and cone sections:

$$
v_{\text {plug }}=\frac{\pi b d_{\text {plog }}^{2}}{4} t_{\text {land }}+\frac{1}{3} \pi\left(h_{\text {plug }}-t_{12 n d}\right)\left[\left(\frac{b d_{\text {plug }}}{2}\right)^{2}+\left(\frac{s d_{\text {plug }}}{2}\right)^{2}+\frac{b d_{\text {plug }}}{2} \frac{s d_{\text {plug }}}{2}\right]
$$

Weight of plug: $\quad \mathrm{W}_{\text {plug }}=\rho_{\text {st }} \mathrm{V}_{\text {plug }} \quad \mathrm{W}_{\text {plug }}=50 \mathrm{lb}$

Weight of plug and contents: $\mathrm{W}_{\mathrm{ps}}=\mathrm{W}_{\text {cost }}+\mathrm{W}_{\mathrm{p} \text { pus }} \cdot \mathrm{W}_{\mathrm{po}}=86 \mathrm{lb}$

$$
\text { Energy of drop: } \quad E_{d r}=W_{d r} h_{d r o p} . \quad E_{d r}=24,650 \mathrm{ft}-1 \mathrm{~b}
$$

Bolt loading from internal pressure:

Evaluate bolts per NUREG/CR-6007 (LLNL 1993). Determine required bolt torque per ASME Section VIII (ASME 1992). 


\section{ENGINEERING SAFETY EVALUATION}

Subject Pacific Northwest Concrete Waste Drum Failure Thresholds Originator S. S. Shiraga . Page 4 of 11 Checker J.J. Mahoney Date $08 / 01 / 96$ Date $08 / 19 / 96$

Assumed differential pressure:

$$
\mathrm{p}_{t}=11.2 \mathrm{psi}
$$

Poisson's ratio:

$$
v_{\mathrm{s}}=0.29
$$

Thickness of wall:

$$
t_{w}=0.322 \mathrm{in} .
$$

Elastic modulus of bolt:

$$
E_{\text {botl }}=28.6 \cdot 10^{6} \text { psi }
$$

Elastic moduius of sst: $\mathrm{E}_{\mathrm{sq}}=27.6 \cdot 10^{6} \mathrm{psi}$

\section{Bolts:}

Number: $\quad \mathrm{n}_{\mathrm{b}}=12 \quad$ Nominal diameter: $\quad \mathrm{D}_{\mathrm{b}}=0.5 \mathrm{in.} \quad$ Pitch: $13 / \mathrm{in}$.

Diameter of bolt circle: $\quad D_{\mathrm{lb}}=14.75 \mathrm{in.} \quad$ Inside diameter: $\mathrm{d}_{\mathrm{in}}=10.75 \mathrm{in}$.

Bolt length between top and bottom of lid: $\quad L_{0}=t_{p l}-0.251$ in. Flange thickness: $\quad t_{3 f}=1.5$ in.

Assume worst case operating temperature of $200^{\circ} \mathrm{F}$, values from ASME, Section II (ASME 1995) and temperature correction factors from Military Handbook - Metallic Materials and Elements for Aerospace Vehicle Structures (Military Handbook 1994):

Assume bolt yield (ASTM A449): $\quad s_{y}=0.95(92 \mathrm{ksi})$

$$
\mathrm{s}_{\mathrm{y}}=87.4 \mathrm{ksi}
$$

Assume ultimate: $\quad s_{\mathrm{u}}=0.98(120 \mathrm{ksi})$

$$
\mathrm{s}_{\mathrm{u}}=117.6 \mathrm{ksi}
$$

Allowable: $\quad s_{\mathrm{m}}=23 \mathrm{ksi}$

$$
\text { Assume gasket factors: } \quad \mathrm{y}_{\mathrm{gss}}=200 \mathrm{psi} \quad \mathrm{m}=1.0
$$

Location of gasket load reaction:

$$
\text { Width of gasket: } \quad b_{0}=\frac{1}{2} \frac{(13.25-11.25)}{2} \text { in. } \quad b_{0}=0.5 \text { in. }
$$

$$
\begin{array}{lll}
\text { Effective width of gasket: } \quad b=0.5 \sqrt{\frac{b_{o}}{\text { in. }}} \text { in. } & b=0.35 \text { in. } \\
\text { Location: } \quad D_{1 g}=13.25 \text { in. }-2 b & D_{1 \mathrm{~g}}=12.54 \text { in. }
\end{array}
$$

Minimum preload to seat gasket: $\quad F_{2 p \min }=\frac{\pi D_{1 g} b y_{g 2 s}}{n_{b}} \quad F_{2 p \min }=232 \mathrm{lb}$

Minimum operating gasket load: $\quad F_{\text {oqmin }}=\frac{2 \pi D_{1 g} b m p_{f}}{n_{b}} \quad F_{\text {opmin }}=26 \mathrm{lb}$

Therefore, seating load is larger; however, to maintain bolt tightness, increase preload to:

$$
\mathrm{T}_{\mathrm{pro}}=25 \mathrm{lb}-\mathrm{ft} \quad \text { Recommended torque for alloy steel bolts. }
$$


ENGINEERING SAFETY EVALUATION

Subject Pacific Northwest Concrete Waste Drum Failure Thresholds Page 5 of 11 Originator S.S. Shiraga Date $\frac{5}{0} / 01 / 96$

Checker J. J. Mahoney

Date $08 / 19 / 96$

Non-prying tensile force on bolts due to preload:

Friction factor assuming use Never-Seez: $\quad k_{\text {bott }}=0.18$

$$
F_{\text {apre }}=\frac{T_{\text {pre }}}{k_{\text {bolt }} D_{b}} \quad F_{\text {apre }}=3,333 \mathrm{lb}
$$

Residual torque on bolt: $\quad M_{\mathrm{t}}=0.5 \mathrm{~T}_{\text {pre }}$

Pressure load on bolt:

Non-prying tensile force per bolt: $\quad F_{\text {spress }}=\frac{\pi D_{28}^{2} p_{t}}{4 n_{b}} \quad F_{\text {apress }}=115 \mathrm{lb}$

Shear force per bolt: $\quad F_{\text {spress }}=\frac{\pi E_{s t} t_{p l} p_{f} D_{p b}{ }^{2}}{2 n_{0} E_{s s t} t_{w}\left(1-v_{s}\right)} \quad F_{s p r e s c}=1,046 \mathrm{lb}$

Fixed edge prying force: $\quad \dot{F}_{\text {fpress }}=\frac{D_{\mathrm{b}} \mathrm{p}_{\mathrm{f}}}{4} \quad \mathrm{~F}_{\mathrm{fpress}}=41 \frac{\mathrm{lb}}{\mathrm{in}}$

Fixed edge prying moment: $\quad \mathrm{M}_{\mathrm{fpress}}=\frac{\mathrm{p}_{\mathrm{f}} \mathrm{D}_{\mathrm{lb}}{ }^{2}}{32} \quad \mathrm{M}_{\mathrm{fpress}}=76 \mathrm{lb} \frac{\text { in }}{\text { in }}$

Oblique drop:

Using the concept of flow stress of steel, and idealizing the package as a hollow right angle cylinder, determine the deceleration loads.

Derivation of oblique crush equations:

CG of package assumed $6 \mathrm{in}$. from bottom of shield plug.

Distance from top of package to $\mathrm{CG}$, scaled from . Pacific Northwest drawing $\mathrm{H}-3-304541$ (Pacific Northwest 1996):

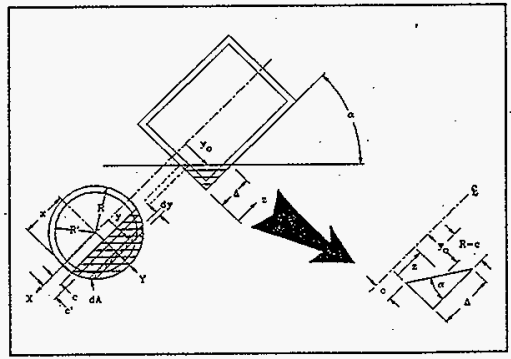

$$
\begin{aligned}
& s_{\text {top }}=15 \mathrm{in.} \\
& \gamma=\operatorname{atan} \frac{\mathrm{id}_{d}}{\mathrm{~s}_{\mathrm{tog}}} \quad \gamma=56.31^{\circ} .
\end{aligned}
$$




\section{ENGINEERING SAFETY EVALUATION}

Subject Pacific Northwest Concrete Waste Drum Failure Thresholds Page 6 of 11

Originator S. S. Shiraga Date $08 / 01 / 196$

Checker J. J. Mahoney

Assumed over CG corner drop angle: $\alpha=90^{\circ}-\gamma$

$\alpha=33.69^{\circ}$

Determined crushed volume of a solid cylindrical end:

By symmetry: $d A=2 x d y$

and for a circle: $\quad \mathrm{r}^{2}=\mathrm{x}^{2}+\mathrm{y}^{2}$

Therefore cross-sectional crush area; $\quad A=\int_{c}^{R} 2 \sqrt{x^{2}-y^{2}} d y$

Therefore volume of crush is: $\quad \mathrm{V}=\int_{0}^{\Delta} \cdot A d z=\int_{0}^{\Delta} \quad \int_{c}^{R} 2\left(\sqrt{R_{d}^{2}-y^{2}}\right) d y d z$

By integrating with respect to $y: \quad V=\int_{0}^{\Delta}\left(\frac{\pi R_{d}^{2}}{2}-y_{0} \sqrt{R_{d}{ }^{2}-y_{0}{ }^{2}}-R_{d}{ }^{2} \operatorname{asin}\left(\frac{y_{0}}{R_{d}}\right)\right) d z$

Since by geometry: $\quad \Delta=\frac{R_{\mathrm{d}}-\mathrm{c}}{\tan (\alpha)} \quad$ and $\quad \mathrm{y}_{0}=\mathrm{c}+\mathrm{z} \tan (\alpha)$

The volume then becomes:

$$
V=\int_{0}^{\Delta}\left[\frac{\pi R_{d}^{2}}{2}-(c+z \tan (\alpha)) \sqrt{R_{d}^{2}-(c+z \tan (\alpha))^{2}}-R_{d}^{2} \operatorname{asin} \frac{c+z \tan (\alpha)}{R_{d}}\right] d z
$$

Integrating by parts:

$$
V=\frac{R_{d}^{2} \sqrt{R_{d}^{2}-c^{2}}+c R_{d}^{2} \operatorname{asin}\left(\frac{c}{R_{d}}\right)-\frac{\pi R_{d}^{2} c}{2}-\frac{1}{3}\left(R_{d}^{2}-c^{2}\right)^{\frac{3}{2}}}{\tan (\alpha)} .
$$

Idealize the drum as a hollow cylinder with closed ends. To determine total volume of deformation subtract volume of solid outer cylinder from volume of solid inner cylinder and solve for $\mathrm{c}$.

Volume of outer solid cylinder:

$$
V_{\text {ose }}=\frac{R_{d}^{2} \sqrt{R_{d}^{2}-c^{2}}+c R_{d}^{2} \operatorname{asin}\left(\frac{c}{R_{d}}\right)-\frac{\pi R_{d}^{2} c}{2}-\frac{1}{3}\left(R_{d}^{2}-c^{2}\right)^{\frac{3}{2}}}{\tan (\alpha)}
$$

Volume of inner solid cylinder:

$$
V_{i s c}=\frac{R_{d}^{\prime 2} \sqrt{R_{d}^{\prime 2}-c^{\prime 2}}+c^{\prime} R_{d}^{\prime 2} a \sin \left(\frac{c^{\prime}}{R^{\prime}}\right)-\frac{\pi R_{d}^{\prime 2} c^{\prime}}{2} \frac{1}{3}\left(R_{d}^{\prime 2}-c^{\prime 2}\right)^{\frac{3}{2}}}{\tan (\alpha)}
$$




\section{ENGINEERING SAFETY EVALUATION}

Subject Pacific Northwest Concrete, Waste Drum Failure Thresholds

Originator S.S. Shiraga

Page 7 of 11

Checker

By geometry: $R_{d}^{\prime}=R_{d}-t_{d}$

and

$$
c^{\prime}=c+t_{d} \tan (\alpha)
$$

By substitution:

$$
\begin{aligned}
& V_{i s c}=\frac{\left[\begin{array}{l}
\left(R_{d}-t_{d}\right)^{2}-\sqrt{\left(R_{d}-t_{d}\right)^{2}-\left(c+t_{d} \tan (\alpha)\right)^{2}} \\
+\left(c+t_{d} \tan (\alpha)\right)\left(R_{d}-t_{d}\right)^{2} \operatorname{asin}\left(\frac{c+t_{d} \tan (\alpha)}{R_{d}+t_{d}}\right) \\
+\left[\frac{-\pi\left(R_{d}-t_{d}\right)^{2}\left(c+t_{d} \tan (\alpha)\right)}{2}-\frac{1}{3}\left[\left(R_{d}-t_{d}\right)^{2}-\left(c+t_{d} \tan (\alpha)\right)^{2}\right]^{\frac{3}{2}}\right]
\end{array}\right]}{\tan (\alpha)} \\
& \text { Define: } \quad \mathrm{R}_{\mathrm{d}}=\frac{\mathrm{od}_{\mathrm{d}}}{2} \quad \mathrm{R}_{\mathrm{l}}=\frac{\mathrm{id}_{\mathrm{d}}}{2}-\mathrm{t}_{\mathrm{i}}
\end{aligned}
$$

Using the concept of flow stress (ORNL 1970):

By conservation of energy and assuming a coefficient of restitution of 0 .

$$
\mathrm{E}_{\mathrm{dr}}=\sigma_{\mathrm{s} s} \mathrm{~V}_{\mathrm{tox}}
$$

Using Mathcad Find function to solve for c:

\section{Given}

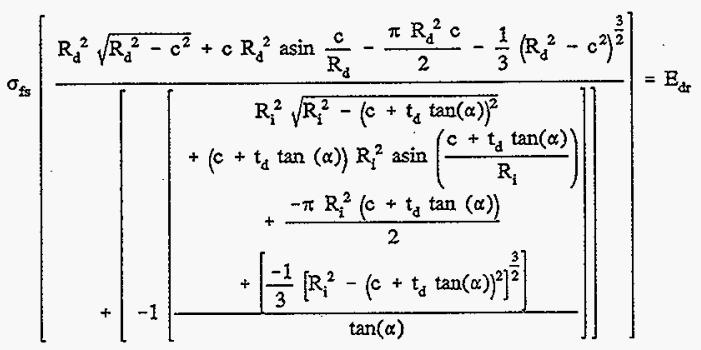

$c=8.5$ in. 


\section{ENGINEERING SAFETY EVALUATION .}

$\begin{array}{ll}\text { Subject_Pacific Northwest Concrete Yaste Drum Failure Thresholas } & \text { Page } \frac{8}{08} \frac{11}{08 / 01 / 96} \\ \text { Originator S. S. Shiraga } & \text { Date } \\ \text { Checker_J. J. Mahoney } & \text { Date 08/19/96 }\end{array}$

Based on this estimate deformation, assume crushed area is an ellipse:

Major axis: $\quad a=\frac{R_{d}-c}{\sin (\alpha)} \quad a=5.06 \mathrm{in}$.

Minor axis:

$$
\begin{aligned}
& \beta=\operatorname{acos} \frac{c}{R_{d}} \quad \beta=41.27^{\circ} . \\
& b=\frac{R_{d} \sin (\beta)}{2} \quad b=3.73 \text { in. }
\end{aligned}
$$

Ignore energy absorption contribution of localized concrete failure.

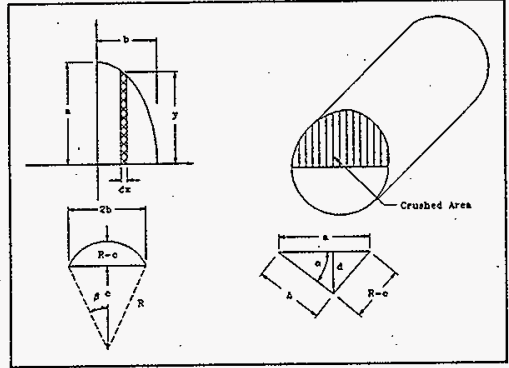

Width of impact: $\quad R_{d}-c=2.81 \mathrm{in}$.

Depth of deformation: $\mathrm{d}=\mathrm{b} \sin (\alpha)$

$d=2.07$ in.

Deceleration load based on deformation:

$$
g_{d e c}=\frac{h_{\text {drop }}}{d} \quad g_{d e c}=99
$$

Assume uniform impact loading on bolts (LLNL 1993):

Assumed dynamic load factor: DLF $=1.5$

$$
\begin{aligned}
& \text { Non-prying force: } \quad F_{\text {2imp }}=\frac{1.34\left(\mathrm{~W}_{\mathrm{pc}}+\mathrm{W}_{\mathrm{id}}\right) \mathrm{g}_{\mathrm{dec}} \mathrm{DLF}}{\mathrm{n}_{\mathrm{b}}} \quad \mathrm{F}_{\mathrm{aimp}}=2,210 \mathrm{lb} \\
& \text { Shear load on bolts: } \quad F_{\text {simp }}=\frac{g_{d e c}\left(W_{p c}+W_{\text {bid }}\right) \cos (\alpha) D L F}{n_{b}} \quad F_{\text {simp }}=1,372 \mathrm{lb} \\
& \text { Fixed edge forces: } \quad F_{\text {fimp }}=\frac{1.34\left(\mathrm{~W}_{\mathrm{pc}}+\mathrm{W}_{\mathrm{lid}}\right) g_{\mathrm{dec}} \mathrm{DLF}}{\pi \mathrm{D}_{\mathrm{rb}}} \quad F_{\text {fimp }}=572 \frac{\mathrm{lb}}{\text { in }} \\
& \text { Fixed edge moments: } \quad \mathrm{M}_{\mathrm{fimp}}=\frac{1.34\left(\mathrm{~W}_{\mathrm{id}}+\mathrm{W}_{\mathrm{pc}}\right) \mathrm{g}_{80 \mathrm{c}} \text { DLF }}{8 \pi} \quad \mathrm{M}_{\mathrm{fimp}}=1,055 \mathrm{lb} \frac{\mathrm{in}}{\mathrm{in}} \text {. }
\end{aligned}
$$

Ignore vibration and thermal loading. 


\section{ENGINEERING SAFETY EVALUATION}

Subject Pacific Northwest Concrete Waste Drum Failure Thresholds Page $\frac{9}{08}$ of 11

Preload per unit length of bolt circle: $\quad p_{\mathrm{pro}}=\frac{\mathrm{F}_{\mathrm{aprc}}}{\pi \mathrm{D}_{\mathrm{pb}}} \quad \mathrm{p}_{\mathrm{prc}}=72 \frac{\mathrm{lb}}{\mathrm{in}}$

Load combinations:

$$
\begin{aligned}
& F_{\text {zpre }}=3,333 \mathrm{lb} \text { and } F_{2 a d}=F_{\text {apress }}+F_{\text {simp }} \quad F_{2 \mathrm{dl}}=2,325 \mathrm{lb} \\
& F_{f c}=F_{f \text { fress }}+F_{f i m p} \quad F_{f c}=614 \mathrm{lb} / \mathrm{in} \\
& \mathrm{M}_{\mathrm{fc}}=\mathrm{M}_{\mathrm{fpress}}+\mathrm{M}_{\mathrm{fimp}} \quad \mathrm{M}_{\mathrm{fc}}=1,131 \mathrm{lb} \text { in/in }
\end{aligned}
$$

Additional tensile force due to prying:

Factors: $\quad \mathrm{C} 1=1$

$$
\begin{aligned}
& C 2=\frac{8}{3\left(d_{1 d}-d_{i s}\right)^{2}}\left[\frac{E_{s s} t_{p 1}^{3}}{\left(1-v_{s}\right)}+\frac{\left(d_{1 i d}-d_{i a}\right) E_{s t} t_{i f}^{3}}{D_{1 b}}\right] \frac{L_{b}}{n_{b} D_{b}^{2} E_{b o i t}}
\end{aligned}
$$

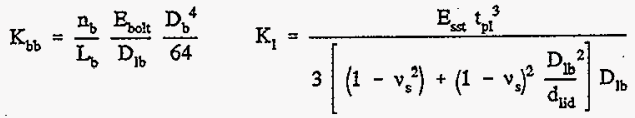

Prying tensile force: $\quad F_{a p}=\frac{\pi D_{3 b}}{I_{b}}\left[\frac{\frac{2 M_{f o}}{\left(d_{\mathrm{lid}}-D_{\mathrm{fb}}\right)}-C 2\left(F_{\mathrm{fc}}-\mathrm{p}_{\mathrm{pro}}\right)}{\mathrm{C} 1+\mathrm{C} 2}\right] \quad F_{\mathrm{ap}}=4,220 \mathrm{lb}$

Bending moment: $\quad M_{b b}=\frac{\pi D_{1 b}}{\mathfrak{n}_{b}} \frac{K_{b b}}{K_{b b}+K_{1}} M_{f c} \quad M_{b b}=806 \mathrm{lb}-$ in

Total force on bolts: $F_{2: 0 x}=F_{2 a 1}+F_{x p} \quad F_{2 a x}=6,545 \mathrm{lb}$

Effective bolt diameter: $\quad D_{b z}=D_{b}-0.9743 \frac{1}{\text { pit }}$

Average tensile stress: $\quad s_{b a}=\frac{1.2732 F_{210 x}}{D_{b a}^{2}} \quad s_{b a}=46,125$ psi 
Average shear stress: $\quad s_{b s}=\frac{1.2732\left(\mathcal{F}_{\text {simp }}+F_{s p r e s s}\right)}{D_{b a}^{2}} \quad s_{b s}=17,043 \mathrm{psi}$

Maximum bending stress:

$$
s_{b b}=\frac{10.186 \mathrm{M}_{b b}}{D_{b b}^{3}} \quad s_{b b}=106,856 \mathrm{psi}
$$

Maximum shear by bolt torsion:

$$
s_{b c}=\frac{5.093 \mathrm{M}_{\mathrm{t}}}{\mathrm{D}_{\mathrm{ba}}{ }^{3}} \quad \mathrm{~s}_{\mathrm{bc}}=9,948 \mathrm{psi}
$$

Maximum stress intensity: $\quad s_{\mathrm{bi}}=\sqrt{\left(\mathrm{s}_{\mathrm{b} z}+\mathrm{s}_{\mathrm{bb}}\right)^{2}+4\left(s_{\mathrm{bs}}+s_{\mathrm{bc}}\right)^{2}} \quad s_{\mathrm{bi}}=162,225 \mathrm{psi}$

Margin of safety based on ASME Section III, Service Level D (ASME 1992) criteria:

$$
\begin{array}{lll}
\text { Average stress: } & \mathrm{MS}_{1}=\frac{0.7 \mathrm{~s}_{\mathrm{y}}}{\mathrm{s}_{\mathrm{bz}}}-1 & \mathrm{MS}_{1}=0.78 \\
\text { Average shear stress: } & \mathrm{MS}_{2}=\frac{0.42 \mathrm{~s}_{\mathrm{y}}}{\mathrm{s}_{\mathrm{bc}}}-1 & \mathrm{MS}_{2}=2
\end{array}
$$

Ratio of average tensile stress to allowable and average shear stress to allowable must be less than 1:

$$
\frac{s_{b 2}}{0.7 s_{u}}+\frac{s_{b s}}{0.42 s_{u}}=1
$$

Bolt failure in shear and tensile.

- Threshold velocity: $\quad$ vel $=\sqrt{2 \mathrm{~g} \mathrm{~h}_{\text {drop }}} \quad$ vel $=23 \mathrm{mph}$

Equivalent thickness of steel for puncture risk:

Approximate thickness of concrete: $\quad t_{\text {conce }}=7$ in.

Pipe thickness: $\quad t_{\text {pips }}=0.322$ in.

Equivalent steel thickness: $\quad t_{e q}=\frac{t_{c o n c}}{12}+t_{d}+t_{\text {pipo }} \quad t_{e q}=0.96$ in. 
HNF-SD-TP-SEP-051 ReV. 1

ENGINEERING SAFETY EVALUATION

Subject Pacific Northwest Concrete, Waste Drum Failure Thresholds . Page 11 of 11 Originator S. S. Shiraga Date $08 / 01 / 96$

Checker J. J. Mahoney Date $08 / 19 / 96$

Puncture failure threshoid (SNL 1976):

- Ratio of relative velocity between package and probe:

$$
\text { ratio }=\sqrt{\frac{t_{e q} \pi s_{y}}{\left(\frac{W_{d r}}{g}\right)}} \quad \text { tatio }=265 \sec ^{-1}
$$




\subsubsection{Engineering Safety Evaluation--NCT Drop}

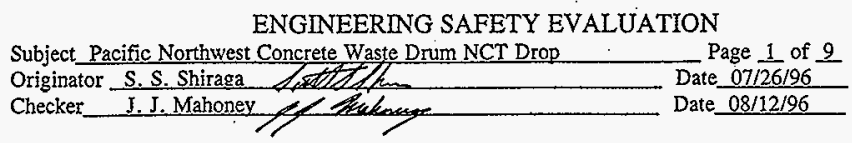

\section{Objective:}

The objective of this evaluation is to determine the NCT $4 \mathrm{ft}$ drop performance of the Pacific Northwest designed concrete lined waste drum.

\section{References:}

ASME, 1992, Boiler and Pressure Vessel Code, Section VII, American Society of Mechanical Engineers, New York, New York.

General Plastics, 1996, LAST-A-FOAM FR-6700 Product Data Sheet, General Plastics, Tacoma, Washington, June 1996.

LLNL, 1993, Stress Analysis of Closure Boits for Shipping Casks, NUREG/CR-6007, TI 006540, Lawrence Livermore National Laboratory, Livermore, California, January 1993.

ORNL, 1970, Cask Designer's Guide, ORNL-NISC-68, Oak Ridge National Laboratory, Oak Ridge, Tennessee, February 1970.

Pacific Northwest, 1996, Concrete-Lined Waste Package, drawing H-3-304541, Rev. 0, Pacific Northwest National Laboratory, Richland, Washington, July 1996.

Young, W. C., 1989, Roark's Formulas for Stress and Strain, Sixth Edition, McGraw-Hill, Inc., New York, New York.

\section{Results and Conclusions:}

The Pacific Northwest package deceleration loading is determined by pressure flow concept developed by ORNL (ORNL 1970). Package performance is evaluated by classical methods. For this evaluation, it is assumed the worst case deceleration loads are generated from a top end drop onto a concrete surface. However, since the outer packaging is a 55-gallon drum comprised of sheet metal, the concrete acts as a hard unyielding surface. For conservatism, the NCT loading from pressure is combined with the drop loadings.

Results of the evaluation show the package 55-gallon drum outer housing deforms and the inner impact limiting foam crushes to decelerate the package during a $4 \mathrm{ft}$ NCT drop. Deformation of the drum and crushing of the foam reduces the deceleration loading on the inner package. The evaluation shows that at these reduced deceleration levels, the contents are retained. This is demonstrated by the positive margins of safety on the closure bolts and lid from the combined loadings. 


\section{ENGINEERING SAFETY EVALUATION}

Subject Pacific Northwest Concrete Waste Drum NCT Drop

Originator S. S. Shiraga

Checker J. J. Mahoney

Page 2 of 9

Date $07 / 26 / 96$

Date $08 / 12 / 96$

\section{Evaluation:}

\section{NCT Impact Evaluation of Pacific Northwest Drum Design}
Assumed drum thickness (18 gage):
$t_{4}=0.0516$ in
Lid thickness (18 gage):
$t_{1}=0.0516$ in

Drum ID: $\quad \mathrm{id}_{\mathrm{d}}=22.5 \mathrm{in}$.

Lid total depth: . . $h_{\text {iid }}=0.75 \mathrm{in.}$

Corner radius: $r_{\text {cos }}=0.25$ in.

Density of stainless steei:

$\rho_{\text {sat }}=0.29 \frac{\mathrm{lb}}{\mathrm{in}^{3}}$

Flow stress of drum material: $\sigma_{i s}=50,000 \mathrm{psi} \quad$ Assumed initial crush height: $h_{d x c}=h_{\text {lid }}-2 r_{c o x}$

Outside diameter of drum: $\quad \mathrm{od}_{\mathrm{a}}=\mathrm{id}_{\mathrm{d}}+2 \mathrm{t}_{\mathrm{a}}$

ID of lid: $\quad i d_{1}=o d_{d}-2 t_{d}-2 t_{1}$

Cross sectional area of drum: $\quad A_{c t}=\frac{\pi}{4}\left(\operatorname{od}_{d}^{2}-i d_{1}^{2}\right)$

Crush volume:

$$
\mathrm{V}_{\mathrm{ct}}=\frac{\pi}{4}\left(\mathrm{dd}_{\mathrm{d}}^{2}-\mathrm{id}_{1}^{2}\right) \mathbf{h}_{\mathrm{dec}}
$$

Gross weight of drum: $\mathrm{W}_{\mathrm{dt}}=1,450 \mathrm{lb}$

Drop height: $\quad h_{\text {drog }}=4 \mathrm{ft}$

Weights:

Lid dimensions: $\quad t_{\mathrm{pl}}=0.75 \mathrm{in}$.

Diameter: $\quad d_{\mathrm{ld}}=16.75 \mathrm{in}$.

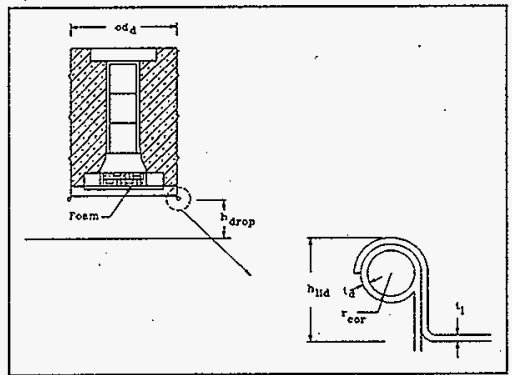

Lid weight: $\quad \mathrm{W}_{\mathrm{lid}}=\rho_{\mathrm{sst}} \frac{\pi \mathrm{d}_{\mathrm{ldd}}{ }^{2}}{4} \mathrm{t}_{\mathrm{p} 1} \quad \mathrm{~W}_{\mathrm{lid}}=48 \mathrm{lb}$

Weight of contents: $\quad \mathrm{W}_{\mathrm{coxt}}=36 \mathrm{lb}$

$$
\begin{aligned}
& \text { Plug dimensions: } \quad b \mathrm{~d}_{\text {plug }}=10.05 \text { in. } \quad \mathrm{sd}_{\text {plug }}=8.25 \text { in. } \\
& t_{\text {iaxd }}=0.5 \mathrm{in.} \quad h_{\text {plos }}=2.5 \mathrm{in.}
\end{aligned}
$$




\section{ENGINEERING SAFETY EVALUATION}

Subject Pacific Northwest Concrete Waste Drum NCT Drop

Originator S. S. Shiraga

Page 3 of 9

Checker J.J. Mahoney

Date $07 / 26 / 96$

Date $08 / 12 / 96$

Volume of plug, plate, and cone sections:

$$
v_{\text {plug }}=\frac{\pi b d_{\text {plug }}^{2}}{4} t_{\text {iasd }}+\frac{1}{3} \pi h_{\text {piug }}-t_{\text {ladd }}\left[\left(\frac{b d_{\text {plug }}}{2}\right)^{2}+\left(\frac{s d_{\text {plug }}}{2}\right)^{2}+\frac{b d_{\text {plog }}}{2} \frac{s d_{\text {plug }}}{2}\right]
$$

Weight of plug: $\quad \mathrm{W}_{\text {plug }}=\rho_{\text {stt }} \mathrm{V}_{\text {phg }}$

$\mathrm{W}_{\mathrm{puz}}=50 \mathrm{lb}$

Weight of plug and contents: $\quad \mathrm{W}_{\mathrm{p} c}=\mathrm{W}_{\mathrm{cons}}+\mathrm{W}_{\mathrm{plug}}$

$\mathrm{W}_{\mathrm{pc}}=86 \mathrm{lb}$

Energy of drop: $\quad E_{\mathrm{dr}}=\mathrm{W}_{\mathrm{dr}} h_{\text {drop }}$

$E_{d r}=5,800 \mathrm{ft}-1 \mathrm{~b}$

Energy absorbed by crush of drum:

Drum rim radius: $\quad r_{c r}=r_{c o r}+t_{d}$

$$
\mathrm{r}_{c t}=0.3 \mathrm{in} \text {. }
$$

Assume rim ring crushes a full radius at first iteration: $\quad \delta_{\mathrm{cr}}=\mathrm{r}_{\mathrm{cr}}$

Energy absorbed in rim crush (ORNL 1970):

$$
E_{\text {rima }}=\frac{\sigma_{f s}\left(t_{d}+t_{d}\right)^{2} \pi o d_{d}}{r_{c r}}\left(\delta_{\alpha x}+0.4 \frac{\delta_{\alpha x}^{2}}{r_{c r}}\right) \cdot E_{\text {rima }}=4,412 \mathrm{ft}-\mathrm{lb}
$$

Energy absorbed in crush of drum top end: $\quad E_{d \text { dum }}=\frac{h_{d r c} A_{c r}\left[\sigma_{f s}\left(t_{d}+t_{1}\right)\right]}{\frac{o d_{d}}{2}} \quad E_{d r u m}=69 \mathrm{ft}-1 b$

Energy absorbed by drim Jid:

$$
E_{\text {rim }}=E_{d r}-E_{d r u m}
$$

$$
\mathrm{E}_{\text {rim }}=5,731 \mathrm{ft}-\mathrm{lb}
$$

Determine deformation of rim after crush of drum top end:

Given:

$$
\frac{\sigma_{\mathrm{fs}}\left(\mathrm{t}_{\mathrm{d}}+\mathrm{t}_{\mathrm{d}}\right)^{2} \pi \mathrm{od} d}{\mathrm{r}_{\mathrm{cr}}} \delta_{c r}+0.4 \frac{\delta_{c \mathrm{c}}^{2}}{\mathrm{r}_{\mathrm{cr}}}-\mathrm{E}_{\mathrm{tim}}=0 \mathrm{lb}-\mathrm{ft}
$$

Deformation of rim: $\quad$ diff $=$ find $\delta_{\mathrm{kr}}$ diff $=0.37$ in

Total deformation of drum: $\quad \operatorname{def}=$ diff $+h_{\text {dra }}$ def $=0.62 \mathrm{in}$.

Deceleration loading factor: $\quad g_{1}=\frac{h_{\text {drop }}}{\text { def }} \quad g_{1}=78$ 


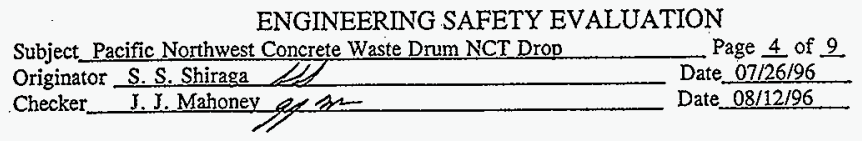

Inner foam parameters, LAST-A-FOAM, FR-6704, Density of $4 \mathrm{lb} / \mathrm{cuft}$ (General Plastics 1996):

Foam voiume:

$$
\begin{aligned}
& \text { Foam diameter: } \quad d_{\text {foam }}=9.0 \mathrm{in.} \quad \text { Height: } \quad h_{\text {foam }}=2.0 \mathrm{in} \text {. } \\
& \text { Volume: } \quad V_{\text {foam }}=\frac{\pi}{4} d_{\text {foam }}^{2} h_{\text {foam }} . \quad V_{\text {foom }}=127 \text { in }^{3} \\
& \text { Crush: } \quad \mathrm{A}_{\text {form }}=\frac{\pi}{4} \mathrm{~d}_{\text {foam }}^{2} \quad \mathrm{~A}_{\text {form }}=64 \mathrm{in}^{2} \\
& \text { Energy: } \quad E_{p c}=W_{p c} h_{d r o p} \quad \cdot E_{p c}=343 \mathrm{ft}-1 b
\end{aligned}
$$

Assume a stain and iterate with crush strength to match stain and stress for strain $<60 \%$, and assumed temperature of $75^{\circ} \mathrm{F}$.

Crush strength: $\quad s_{\mathrm{st}}=94 \mathrm{psi}$

Deformation of foam: $\quad \delta \mathrm{h}=\frac{\mathrm{E}_{\mathrm{pc}}}{\pi\left(\frac{\mathrm{d}_{\mathrm{foam}}}{2}\right)^{2} \mathrm{~s}_{\mathrm{sc}}} \quad \delta \mathrm{h}=0.69 \mathrm{in}$.

Strain of foam: $\quad \frac{\delta \mathrm{h}}{\mathrm{h}_{\text {foam }}}=0.34$

Deceleration loading factor: $\quad \mathrm{g}_{\text {foam }}=\frac{\mathrm{h}_{\text {doop }}}{\delta \mathrm{h}} \quad \mathrm{g}_{\mathrm{foam}}=70$

Bolt loađing from internal pressure:

Evaluate bolts per NUREG/CR-6007 (LLNL 1993). Determine required bolt torque per ASME Section VIII (ASME 1992).

Assumed differential pressure:

$\mathrm{p}_{\mathrm{f}}=11.2 \mathrm{psi}$

Poisson's ratio:

$\nu_{s}=0.29$

Thickness of wall: $\quad t_{\psi}=0.322 \mathrm{in}$.

Elastic modulus of bolt:

$$
E_{8 \infty t}=28.6 \cdot 10^{6} \mathrm{psi}
$$

Elastic modulus of sst: $E_{\mathrm{ss}}=27.6 \cdot 10^{6} \mathrm{psi}$

Bolts (1/2-13 UNC-2A):

Number:

$\mathrm{n}_{\mathrm{b}}=12$

Nominal diameter:

$\mathrm{D}_{\mathrm{b}}=0.5 \mathrm{in}$.

Pitch: pit $=13 / \mathrm{in}$.

Diameter of bolt circle:

$$
\mathrm{D}_{\mathrm{Jb}}=14.75 \text { in. }
$$

Inside diameter:

$\mathrm{d}_{\mathrm{i2}}=10.42 \mathrm{in}$. 


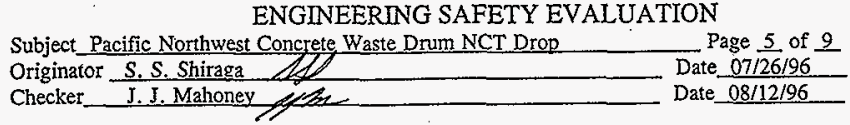

Bolt length between top and bottom of lid: $\quad L_{b}=t_{p l}$

Flange thickness: $\quad . \mathrm{t}_{\mathrm{lf}}=1.5 \mathrm{in}$.

Assume worst case operating temperature of $200^{\circ} \mathrm{F}$ :

Bolt yield (ASTM A449): $\quad s_{y}=92 \mathrm{ksi} \quad$ Bolt ultimate: $s_{\mathrm{u}}=1.20 \mathrm{ksi}$

Allowable: $\quad s_{\mathrm{m}}=2 / 3 \mathrm{~s}_{\mathrm{y}} \quad \mathrm{s}_{\mathrm{m}}=61 \mathrm{ksi}$

Assume gasket factors: $\quad \mathrm{y}_{\mathrm{gas}} \doteq 200 \mathrm{psi} \quad \mathrm{m}=1.0$

Location of gasket load reaction:

$$
\begin{array}{ll}
\text { Width of gasket: } \quad b_{0}=\frac{1}{2} \frac{(13.25-11.25)}{2} \text { in. } \quad b_{0}=0.5 \text { in. } \\
\text { Effective width of gasket: } \quad b=0.5 \sqrt{\frac{b_{0}}{\text { in. }}} \text { in. } & b=0.35 \text { in. } \\
\text { Location: } \quad \dot{D}_{1 \mathrm{~g}}=13.25 \text { in. }-2 \mathrm{~b} \quad D_{\mathrm{lg}}=12.54 \text { in. }
\end{array}
$$

Minimum preload to seat gasket: $\quad F_{2 p \min }=\frac{\pi D_{18} b y_{g a s}}{D_{b}} \quad F_{\text {apmin }}=232 \mathrm{lb}$

Minimum operating gasket load: $\quad \mathrm{F}_{\text {opmin }}=\frac{2 \pi D_{1 g} b \mathrm{~m} \mathrm{p}_{\mathrm{f}}}{\mathrm{n}_{\mathrm{b}}} \quad \mathrm{F}_{\text {opmin }}=26 \mathrm{Ib}$

Therefore, seating load is larger; however, to maintain bolt tightness, increase preload to:

$$
\mathrm{T}_{\text {prc }}=25 \mathrm{lb}-\mathrm{ft} \quad \text { Recommended torque for alloy steel bolts. }
$$

Non-prying tensile force on bolts due to preload:

Friction factor assuming use Never-Seez: $\quad k_{\text {bolt }}=0.18$

$$
F_{\mathrm{spro}}=\frac{T_{\mathrm{pre}}}{\mathrm{k}_{\mathrm{bolt}} \mathrm{D}_{\mathrm{b}}} \quad F_{\mathrm{apre}}=3,333 \mathrm{lb}
$$

Residual torque on bolt: $\quad \mathrm{M}_{\mathrm{t}}=0.5 \mathrm{~T}_{\text {pre }}$ 


\section{ENGINEERING SAFETY EVALUATION}

Subject Pacific Northwest Concrete Waste Drum NCT Drop

Originator S. S. Shiraga

Page 6 of 9

Checker

Pressure load on boit:

Non-prying tensile force per bolt: $\quad F_{\text {apress }}=\frac{\pi D_{18}^{2} p_{f}}{4 n_{b}} \quad F_{a p r e s s}=115 \mathrm{lb}$

Shear force per bolt: $\quad F_{\text {spress }}=\frac{\pi E_{s t} t_{p l} \cdot p_{f} D_{l b}^{2}}{2 n_{b} E_{s s t} t_{w l}\left(1-v_{s}\right)} \quad F_{s p r e s s}=1,046 \mathrm{lb}$

Fixed edge prying force: $\quad F_{\text {fpress }}=\frac{D_{\mathrm{tb}} p_{\mathrm{f}}}{4} \quad F_{\text {fpress }}=41 \frac{\mathrm{lb}}{\text { in }}$

Fixed edge prying moment: $\quad M_{\text {fpress }}=\frac{p_{f} D_{1 b}{ }^{2}}{32} \quad M_{\text {fpress }}=76 \mathrm{lb} \frac{\text { in }}{\text { in }}$

Uniform impact loading on bolts:

Assume flat bottom drop. Since design shows lid surrounded by concrete, assume lid is protected.

Assume dynamic load factor: $\quad$ DLF $=1$

$$
\begin{array}{lll}
\text { Non-prying force: } & \mathrm{F}_{\text {aimp }}=\frac{1.34\left(\mathrm{~g}_{\mathrm{foam}} \mathrm{W}_{\mathrm{pc}}+\mathrm{g}_{1} \mathrm{~W}_{\mathrm{Lid}}\right) \mathrm{DLF}}{\mathrm{n}_{\mathrm{b}}} \quad \mathrm{F}_{\text {simp }}=1,083 \mathrm{lb} \\
\text { Fixed edge forces: } & \mathrm{F}_{\text {fimp }}=\frac{1.34\left(\mathrm{~g}_{\mathrm{fogm}} \mathrm{W}_{\mathrm{pc}}+\mathrm{g}_{1} \mathrm{~W}_{\mathrm{lid}}\right) \mathrm{DLF}}{\pi \mathrm{D}_{\mathrm{lb}}} \quad \mathrm{F}_{\text {fimp }}=280 \frac{\mathrm{lb}}{\mathrm{in}} \\
\text { Fixed edge moments: } & \mathrm{M}_{\text {fimp }}=\frac{1.34\left(\mathrm{~g}_{1} \mathrm{~W}_{\mathrm{Ld}}+\mathrm{g}_{\text {foam }} \mathrm{W}_{\mathrm{pc}}\right) \mathrm{DLF}}{8 \pi} \quad \mathrm{M}_{\text {fimp }}=517 \mathrm{lb} \frac{\mathrm{in}}{\mathrm{in}}
\end{array}
$$

Ignore vibration and thermal loading.

Preload per unit length of bolt circle: $\quad p_{\text {pre }}=\frac{F_{\mathrm{aprec}}}{\pi \mathrm{D}_{1 \mathrm{~b}}} \quad \mathrm{p}_{\mathrm{ptc}}=72 \frac{\mathrm{lb}}{\mathrm{in}}$

Load combinations:

$$
\begin{aligned}
& F_{\text {apre }}=3,333 \mathrm{lb} \quad \text { and } \quad F_{\text {aal }}=F_{\text {apress }}+F_{\text {aimp }} \quad \cdot \quad F_{211}=1,198 \mathrm{lb} \\
& F_{f c}=F_{\text {fpress }}+F_{\text {fimp }} . \quad F_{f c}=322 \mathrm{lb} / \mathrm{in} \\
& \mathrm{M}_{\mathrm{fc}}=\mathrm{M}_{\text {fpress }}+\mathrm{M}_{\text {finp }} \quad \mathrm{M}_{\mathrm{kc}}=593 \mathrm{lb} \mathrm{in} / \mathrm{in}
\end{aligned}
$$




\section{ENGINEERING SAFETY EVALUATION}

Subject Pacific Northwest Concrete Waste Drum NCT Drop

Originator S.S. Shiraga Page 7 of 9

Checker J.J. Mahoney

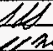
Date $07 / 26 / 96$

Date $08 / 12 / 96$

Additional tensile force due to prying:

Factors: $\quad \mathrm{C} 1=1$

$$
\begin{aligned}
& C 2=\frac{8}{3\left(d_{1 \mathrm{~d}}-d_{i b}\right)^{2}}\left[\frac{E_{s s t} t_{p l}{ }^{3}}{1-v_{s}}+\frac{\left(d_{i d}-d_{i d}\right) E_{s s t} t_{1 f}{ }^{3}}{D_{j b}}\right] \frac{L_{b}}{n_{b} D_{b}{ }^{2} E_{b o l t}} \\
& K_{b b}=\frac{n_{b}}{L_{b}} \frac{E_{\text {bolk }}}{D_{l b}} \frac{D_{b}^{4}}{64} \quad K_{1}=\frac{E_{s c t} t_{p l}^{3}}{3\left[\left(1-v_{s}^{2}\right)+\left(1-v_{s}\right)^{2} \frac{D_{1 b}^{2}}{d_{l i d}}\right] D_{l b}}
\end{aligned}
$$

Prying tensile force: $\quad F_{a p}=\frac{\pi D_{\mathrm{fb}}}{\mathrm{n}_{\mathrm{b}}}\left[\frac{\frac{2 \mathrm{M}_{\mathrm{fc}}}{\left(\mathrm{d}_{\mathrm{lid}}-\mathrm{D}_{\mathrm{pb}}\right)}-\mathrm{C} 2\left(\mathrm{~F}_{\mathrm{fc}}-\mathrm{P}_{\mathrm{prc}}\right)}{\mathrm{C} 1+\mathrm{C}}\right] \quad \mathrm{F}_{\mathrm{sp}}=2,188^{\prime} \mathrm{Ib}$

Bending moment: $\quad \mathrm{M}_{\mathrm{bb}}=\frac{\pi \mathrm{D}_{\mathrm{bb}}}{\mathrm{H}_{\mathrm{b}}} \frac{\mathrm{K}_{\mathrm{bb}}}{\mathrm{K}_{\mathrm{bb}}+\mathrm{K}_{1}} \mathrm{M}_{\mathrm{fc}} \quad \mathrm{M}_{\mathrm{bb}}=300 \mathrm{lb}$-in

Total force on bolts: $F_{a t o t}=F_{\text {aal }}+F_{a p} \quad F_{2 t c t}=3,386 \mathrm{lb}$

Effective bolt diameter: $\quad D_{b 2}=D_{b}-0.9743 \frac{1}{\text { pit }}$

Average tensile stress: $\quad s_{b 2}=\frac{1.2732 \mathrm{~F}_{\mathrm{ptox}}}{\mathrm{D}_{\mathrm{ba}}{ }^{2}} \quad \mathrm{~s}_{\mathrm{ba}}=23,863 \mathrm{psi}$

Average shear stress: $\quad \mathrm{s}_{\mathrm{bs}}=\frac{1.2732 \mathrm{~F}_{\mathrm{sptess}}}{\mathrm{D}_{\mathrm{ba}}{ }^{2}} \quad \mathrm{~s}_{\mathrm{bs}}=7,374 \mathrm{psi}$

Maximum bending stress: $\quad s_{b b}=\frac{10.186 \mathrm{M}_{\mathrm{bb}}}{D_{\mathrm{ba}}{ }^{3}} \quad s_{\mathrm{bb}}=39,744 \mathrm{psi}$

Maximum shear by bolt torsion: $\quad \cdot s_{b t}=\frac{5.093 \mathrm{M}_{\mathrm{t}}}{\mathrm{D}_{\mathrm{ba}}{ }^{3}} \quad \mathrm{~s}_{\mathrm{bt}}=9,948 \mathrm{psi}$

Maximum stress intensity: $\quad s_{b i}=\sqrt{\left(s_{b x}+s_{b b}\right)^{2}+4\left(s_{b s}+s_{b c}\right)^{2}} \quad s_{b i}=72,429$ psi 


\section{ENGINEERING SAFETY EVALUATION}

Subject Pacific Northwest Concrete Waste Drum NCT Drop

Margin of safety:

$$
\begin{aligned}
& \text { Average stress: . } \quad \mathrm{MS}_{1}=\frac{\mathrm{s}_{\mathrm{m}}}{\mathrm{s}_{\mathrm{b3}}}-1 \quad \mathrm{MS} \mathrm{S}_{1}=1.57 \\
& \text { Average shear stress: } \quad \mathrm{MS}_{2}=\frac{0.6 \mathrm{~s}_{\mathrm{mt}}}{\mathrm{s}_{\mathrm{bs}}}-1 \quad \mathrm{MS}_{2}=3.99 \\
& \text { Total stress: } \quad \mathrm{MS}_{3}=\frac{3 . \mathrm{s}_{\mathrm{m}}}{\mathrm{s}_{\mathrm{bi}}}-1 \quad \mathrm{MS}_{3}=1.54
\end{aligned}
$$

Stresses on closure lid:

Material of plate: ASTM A-516 Grade 60 .

Material strength properties: $s_{\mathrm{y}}=32 \mathrm{ksi} \cdot s_{\mathrm{u}}=60 \mathrm{ksi}$

ASME allowable at $200^{\circ} \mathrm{F}: \quad s_{\mathrm{m}}=15 \mathrm{ksi}$

Radius of plate: . $\quad \mathrm{r}_{\mathrm{is}}=\frac{\mathrm{d}_{\text {in }}}{2}$

The system can be considered as a uniformly loaded flat plate which is simply supported (Young 1989, page 429).

$$
\begin{aligned}
& \text { Loading: } \quad \mathrm{q}_{\mathrm{f}}=\frac{\mathrm{g}_{\mathrm{foam}} \mathrm{W}_{\mathrm{pc}}+\mathrm{g}_{\mathrm{I}} \mathrm{W}_{\mathrm{Ld}}}{\pi \mathrm{r}_{\mathrm{is}}{ }^{2}} \\
& \text { Moment at center: } \quad \mathrm{M}_{c}=\frac{\mathrm{q}_{\mathrm{f}} \mathrm{r}_{\mathrm{is}}{ }^{2}\left(1+\mathrm{v}_{\mathrm{s}}\right)}{16} \quad \mathrm{M}_{\mathrm{c}}=635 \mathrm{lb} \frac{\text { in }}{\text { in }}
\end{aligned}
$$

Radial moment: $\quad M_{\mathrm{rp}}=\mathrm{M}_{\mathrm{c}}$

Tangential moment: $\quad M_{\varphi}=M_{c}$

Radial bending stress at center: $\quad \sigma_{\mathrm{rb2}}=\frac{6 \mathrm{M}_{\mathrm{rp}}}{t_{\mathrm{pl}}{ }^{2}} \quad \sigma_{\mathrm{r} b 2}=6,772 \mathrm{psi}$

Tangential bending stress at center: $\quad \sigma_{\mathrm{bb} 2}=\frac{6 \mathrm{M}_{\mathrm{tp}}}{{t_{\mathrm{F} 1}}^{2}} \quad \sigma_{\mathrm{b} 2}=6,772 \mathrm{psi}$ 


\section{ENGINEERING SAFETY EVALUATION}

Subject Pacific Northwest Concrete Waste Drum NCT Drop

Page 9 of 9

Originator S. S. Shiraga

Date $07 / 26196$

Checker J. J. Mahoney

Date $08 / 12 / 96$

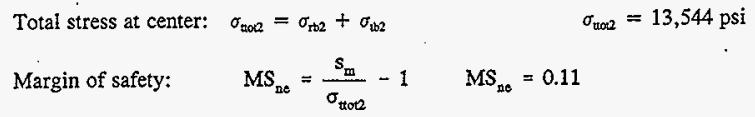


HNF-SD-TP-SEP-051 Rev. 1

This page intentionally left blank. 


\subsection{THERMAL. EVALUATION}

The Concrete-Shielded RH TRU Drum is a package used to transport contaminated hot cell waste from the 327 Building to a solid waste storage facility on the Hanford Site. The waste materials are contained in paint cans with the package. The package was originally designed by ICF Kaiser Hanford Company. The maximum decay heat from the contaminated waste contents is $1 \mathrm{~W}$. This section evaluates the maximum external and internal temperatures of the package for the NCT. The hypothetical accident conditions are based on the fire failure threshold in the risk assessment, Part B, Section 3.4.

\subsection{SUMMARY OF THERMAL PROPERTIES OF MATERIALS}

The outer shell package is a right-angle cylinder manufactured from a UN1A2 55-gal drum. The drum is fabricated from ASTM A-366 (ASTM 1989) galvanized steel. Within the drum is an inner shell manufactured from 8 -in. schedule 40 steel pipe, which is encased in concrete. The concrete is specified to have a maximum density of $2,643 \mathrm{~kg} / \mathrm{m}^{3}\left(165 \mathrm{lb} / \mathrm{ft}^{3}\right)$. Thermal properties of the materials of construction are listed in Table B8-1.

Table B8-1. Summary of Thermal Properties.

\begin{tabular}{|l|l|l|l|l|}
\hline \multicolumn{1}{|c|}{ Material } & \multicolumn{1}{|c|}{$\begin{array}{c}\text { Thermal conductivity } \\
\text { W/m }{ }^{2}-\mathrm{K}\left(\mathrm{Btu} / \mathrm{h}-\mathrm{ft}-{ }^{\circ} \mathrm{F}\right)\end{array}$} & $\begin{array}{c}\text { Specific heat } \\
\mathrm{J} / \mathrm{kg}-\mathrm{K}\left(\mathrm{Btu} / \mathrm{lb}-{ }^{\circ} \mathrm{F}\right)\end{array}$ & $\begin{array}{c}\text { Density } \\
\mathrm{kg} / \mathrm{m}^{3}\left(\mathrm{lb} / \mathrm{ft}^{3}\right)\end{array}$ & $\begin{array}{c}\text { Emissivity } \\
\text { absorptivity }\end{array}$ \\
\hline Galvanized steel & $0.00327(0.0005767)$ & $502(0.120)$ & $7,861(491)$ & $0.89 / 0.8$ \\
\hline Hanford concrete & $0.00012(0.000021)$ & $1042(0.249)$ & $2,643(165)$ & 0.73 \\
\hline Carbon steel & $0.00327(0.0005767)$ & $502(0.120)$ & $7,861(491)$ & 0.45 \\
\hline
\end{tabular}

Source for all material properties: WHC, 1996, Thermal Analysis Methods for Safety Analysis Reports for Packaging, WHC-SD-TP-RPT-005, Rev. 1, Westinghouse Hanford Company, Richland, Washington.

\subsection{THERMAL EVALUATION FOR NCT}

\subsubsection{Conditions To Be Evaluated}

Conditions for evaluation of package performance are based on the thermal requirements of 49 CFR 173.442 for an exclusive use package. These conditions are modified for site-specific conditions that are more extreme than for the conditions cited in 49 CFR 173.442. For onsite shipment evaluation, the package is assumed to be in an ambient temperature environment of 46.1 ${ }^{\circ} \mathrm{C}\left(115^{\circ} \mathrm{F}\right)$ and in direct sunlight at the worst solar angle for 12 hours. The internal heat load from the assumed contents is $1 \mathrm{~W}$.

\subsubsection{Acceptance Criteria}

The acceptance criteria for this package is an exterior surface temperature of no greater than $82^{\circ} \mathrm{C}\left(180^{\circ} \mathrm{F}\right)$ for the specified conditions. Since the package is encased in concrete for shielding, the American Concrete Institute allowable temperature for nuclear applications of concrete ( $\mathrm{ACl} 1989)$ is used as a limiting internal temperature. For this package, which is a concrete steel 
composite of relatively small size, the maximum allowable internal temperature of concrete is $93.3^{\circ} \mathrm{C}\left(200^{\circ} \mathrm{F}\right)$.

\subsubsection{Thermal Model}

The external surface temperature is determined by idealizing the package as a right-angle cylinder and evaluating the loadings using classical methods. The internal package temperature is determined by classical methods and idealizing the internals of the package as concentric shells.

\subsection{THERMAL EVALUATION AND CONCLUSIONS}

By conservative classical methods and idealizing of the package geometry, the evaluation presented in Part B, Section 8.6, demonstrates the package meets the above acceptance criteria. The external surface temperature is conservatively calculated based on assuming the package is exposed to solar heating for a 12-hour period with a worst-case solar declination angle of $30^{\circ}$ from vertical with an ambient temperature of $46.1^{\circ} \mathrm{C}\left(115^{\circ} \mathrm{F}\right)$. Also, it is assumed the package is in still air and insulated on the bottom, therefore losing heat only from the top and around the circumference. Results of utilizing these worst-case assumptions show the maximum external surface temperature of the package is $63.9^{\circ} \mathrm{C}\left(147^{\circ} \mathrm{F}\right)$, which is well under the $82^{\circ} \mathrm{C}\left(180^{\circ} \mathrm{F}\right)$ allowable temperature. The calculated maximum internal package temperature, based on the above heat loading and external surface temperature, is $91.7^{\circ} \mathrm{C}\left(197^{\circ} \mathrm{F}\right)$. This conservative temperature estimate is below the American Concrete Institute maximum allowable concrete temperature. Consequently, the results of this evaluation show the package meets the thermal requirements for the NCT under conservatively extreme conditions.

\subsection{ACCIDENT CONDITIONS}

For this package, no thermal hypothetical accident conditions are evaluated. The risk assessment assumes the package fails in a $800^{\circ} \mathrm{C}\left(1475^{\circ} \mathrm{F}\right)$ fire.

\subsection{REFERENCES}

49 CFR 100-177, "Transportation," Code of Federal Regulations, as amended.

ACI, 1989, ACl Manual of Concrete Practices 1989, Part 4, American Concrete Institute, Detroit, Michigan.

ASTM, 1989, Annual Book of ASTM Standards, Vol. 1.04, American Society of Testing, Philadelphia, Pennsylvania.

WHC, 1996, Thermal Analysis Methods for Safety Analysis Reports for Packaging, WHC-SD-TPRPT-005, Rev. 1, Westinghouse Hanford Company, Richland, Washington. 


\subsection{APPENDIX: ENGINEERING SAFETY EVALUATION--TEMPERATURES}

\begin{tabular}{l} 
ENGINEERING SAFETY EVALUATION \\
Subject Pacific Northwest Concrete Waste Drum Temperatures \\
Originator S. S. Shiraga \\
Checker S. J. Mahoney Dage 1 of 5 \\
\hline
\end{tabular}

I. Objective:

The objective of this evaluation is to determine steady state outside and inside surface temperatures of the package for normal conditions of transport.

II. References:

Jakob, M., and G. A. Hawkins, 1957, Elements of Heat Transfer, John Wiley \& Sons, Inc., New York, New York.

ORNL, 1970, Cask Designer's Guide, ORNL-NISC-68, Oak Ridge National Laboratory, Oak Ridge, Tennessee, February 1970.

WHC, 1993, Thermal Analysis Methods for Safery Analysis Reports for Packaging, WHC-SD-TP-RPT-005, Rev. 1, Westinghouse Hanford Company, Richland, Washington, September 24, 1993.

III. Results and Conclusions:

This evaluation is based on classical steady state heat transfer methods. It also conservatively assumes that the solar angle of declination relative to vertical is at maximum for heat loading for a 12 hour period. Results of the evaluation show the exterior surface of the package reaches a temperature of $148^{\circ} \mathrm{F}$ in that period. The interior surface of the package reaches a temperature of $197^{\circ} \mathrm{F}$. This evaluation shows the exterior of the package does not reach the $182^{\circ} \mathrm{F}$ temperature limit specified by DOT for exclusive use shipments. 


\section{ENGINEERING SAFETY EVALUATION}

Subject_Pacific Northwest Concrete Waste Drum Temperatures____ Page 2

Originator S. S. Shiraga

Date $07 / 31 / 96$

Checker J. J. Mahoney

Date $08 / 15 / 96$

\section{Evaluation:}

\section{NCT Thermal Evaluation for Pacific Northwest Concrete Drum:}

Idealize outside temperature determination on Pacific Northwest drum as a vertical cylinder with flat ends, subjected to direct solar heating in still air at the worst angle for 12 hours.

(Jakob and Hawkins 1957)

Free convection coefficient for a vertical cylinder: $\quad k_{\mathrm{hv}}=0.29 \frac{\mathrm{BTU}}{\mathrm{h} \mathrm{ft}^{2}}$

Free convection coefficient for a horizontal plate: $\quad k_{p}=0.27 \frac{\mathrm{BTU}}{\mathrm{ft}^{2} \mathrm{~h}}$

Length of cylinder: $\quad L_{s}=34.7 \mathrm{in} . \quad O D$ of cylinder: $\quad L_{t}=22.6032$ in.

Surface area of cylinder: $\quad A_{s}=\pi L_{L} L_{s} \quad$ Surface area of plate: $\quad A_{t}=\frac{\pi}{4} L_{t}^{2}$

Total surface area of package: $A_{t x}=A_{t}+A_{4} \quad A_{10 x}=19.9 \mathrm{ft}^{2}$

Combined convection constant: $\quad h d=\left[\frac{k_{\mathrm{hp}} \mathrm{A}_{\mathrm{s}}}{\left(\frac{\mathrm{L}_{\mathrm{s}}}{\mathrm{ft}}\right)^{\frac{1}{4}}}+\frac{\mathrm{k}_{\mathrm{vp}} \mathrm{A}_{\mathrm{t}}}{\left(\frac{\mathrm{L}_{\mathrm{t}}}{\mathrm{ft}}\right)^{\frac{1}{4}}}\right] \mathrm{R}^{-\frac{1}{4}} \quad \mathrm{hd}=5.09 \frac{\mathrm{BTU}}{\mathrm{h}(\mathrm{R})^{\frac{1}{4}}}$

Radient heating constant:

Stefan-Boltzman's natural constant: $\quad \sigma_{\text {so }}=0.1714 \cdot 10^{-8} \frac{\mathrm{BTU}}{\mathrm{h} \mathrm{ft}^{2} \mathrm{R}^{4}}$

Emissivity of steel: $\quad \epsilon_{\mathrm{s}}=0.89$

$$
\mathrm{K}_{1}=\sigma_{\mathrm{sb}} \epsilon_{\mathrm{s}} \mathrm{A}_{\text {tot }} \quad \mathrm{K}_{1}=3.04 \cdot 10^{-8} \frac{\mathrm{BTU}}{\mathrm{h} \mathrm{R}^{4}}
$$

Determination of Solar Loading (ORNL 1970): 


\section{ENGINEERING SAFETY EVALUATION}

Subject_Pacific Northwest Concrete Waste Drum Temperatures

Solar angle of declination relative to vertical for maximum loading: $\theta_{\text {sol }}=30^{\circ}$

Solar heat loading (WHC-SD-TP-RPT-005), hourly loading based on a 12 hour period:

Flat horizontal surfaces:

$$
\mathrm{Q}_{\mathrm{s}}=219 \frac{\mathrm{BTU}}{\mathrm{h} \mathrm{ft}^{2}}
$$

Curved surfaces:

$$
Q_{\mathrm{s} 1}=123 \frac{\mathrm{BTU}}{\mathrm{h} \cdot \mathrm{ft}^{2}}
$$

Internal heat load: $\quad q_{\text {ist }}=1 \mathrm{~W}$

Solar absorptivity, assume same as emissivity:

$$
\alpha_{\text {sol }}=0.8
$$

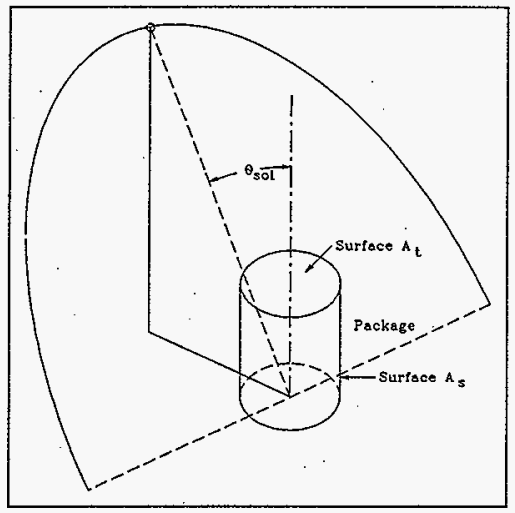

Solar heat load:

$$
q_{s o l}=\alpha_{s o l} Q_{s} A_{t} \cos \theta_{s o l}+Q_{s 1} \frac{A_{s}}{2} \sin \theta_{s o l}
$$

Total heat load:

$$
q_{t}=q_{s o l}+q_{\text {int }} \quad q_{t}=847 \frac{B T U}{h}
$$

Outside ambient temperature is $115^{\circ} \mathrm{F}$ and in Rankine:

$$
T_{0}=(115+459.7) R
$$

Using conservation of energy: $\quad q_{\text {in }}-q_{\alpha s}=0$.

Then by substitution:

$$
q_{t}-q_{r a d}-q_{c o s}=0
$$

or

$$
q_{t}-K_{t}\left(T_{f}^{4}-T_{0}^{4}\right)-h d\left(T_{f}-T_{0}\right)^{\frac{3}{4}}=0
$$

Solve for $T_{f}$ which is temperature at the surface using roots of the equation solution:

$$
T_{f 1}=\operatorname{root}\left[q_{t}-K_{1}\left(T_{f}^{4}-T_{0}^{4}\right)-h d\left(T_{f}-T_{0}\right)^{\frac{1}{4}}, T_{f}\right]
$$




\section{ENGINEERING SAFETY EVALUATION}

Subject Pacific Northwest Concrete Waste Drum Temperatures Originator S. S. Shiraga Page 4 of 5 Checker

External surface temperature: $T_{\mathfrak{n}}=608 \mathrm{R}$

Determine temperature in ${ }^{\circ} \mathrm{F}: \quad \mathrm{T}_{\mathrm{ff}}=\left|\frac{\mathrm{T}_{\mathrm{f1}}}{\mathrm{R}}-\frac{459.7 \mathrm{R}}{\mathrm{R}}\right| \quad \mathrm{T}_{\mathrm{ff}}=148^{\circ} \mathrm{F}$

Heat transfer into the cask:

Cylindrical length of cask: $\quad \mathrm{L}_{\mathrm{c}}=34.7 \mathrm{in}$.

Assume one-dimensional heat transfer:

$$
q_{f}=\frac{2 \pi L_{c}\left(T_{1}-T_{4}\right)}{\frac{\ln \left(\frac{r_{2}}{r_{1}}\right)}{k_{c 51}}+\frac{\ln \left(\frac{r_{3}}{r_{2}}\right)}{k_{85}}+\frac{\ln \left(\frac{r_{4}}{r_{3}}\right)}{k_{c 51}}}
$$

Solve for $T_{1}$ :

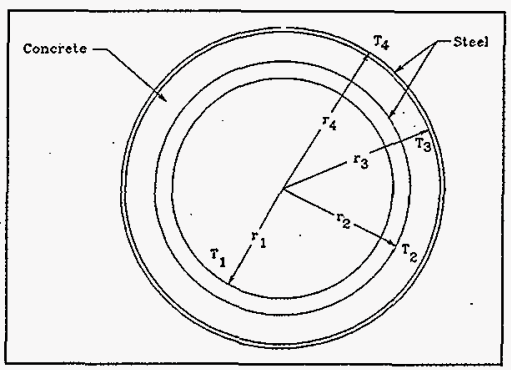

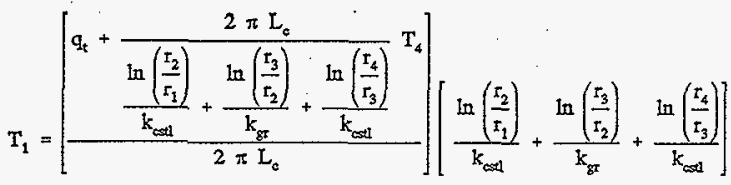

Thermal properties of materials (WHC-SD-TP-RPT-005):

$$
\begin{array}{ll}
\text { Grout: } & \mathbf{k}_{\mathrm{Bt}}=0.000021 \frac{\mathrm{BTU}}{\mathrm{sec} \text { in. }} \\
\text { Steel: } & \mathbf{k}_{\mathrm{cst}}=0.0005767 \frac{\mathrm{BTU}}{\mathrm{sec} \mathrm{in} .}
\end{array}
$$

Dimensional properties of package:

$$
\text { Thickness of steel: } \quad t_{w}=0.365 \mathrm{in} . \quad \text { Outer shell radius: } \quad \dot{r}_{4}=\frac{L_{t}}{2}
$$




\section{ENGINEERING SAFETY EVALUATION}

Subject Pacific Northwest Concrete Waste. Drum Temperatures

Originator S. S. Shiraga

Checker J.J. Mahoney

Page 5 of 5

Date $07 / 31 / 96$

Date 08/15/96

Thickness of drum: $\quad t_{d r}=0.0516 \mathrm{in}$.

Cavity radius: $\quad r_{1}=\frac{7.981 \text { in. }}{2} \quad$ Outer shell inner radius: $\quad r_{3}=r_{4}-t_{d r}$

Inner shell outer radius: $\quad \mathrm{r}_{2}=\mathrm{r}_{1}+\mathrm{t}_{\mathrm{w}} \quad$ Outer shell temperature: $\quad \mathrm{T}_{4}=\mathrm{T}_{\mathrm{ft}}$

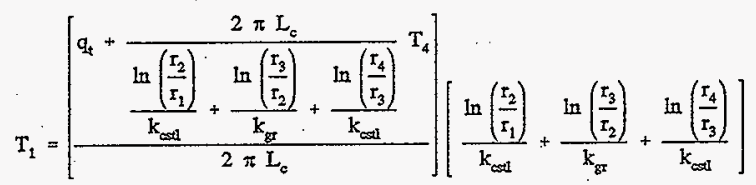

Temperature on the inner surface of the cask: $T_{1}=197^{\circ} \mathrm{F}$ 
HNF-SD-TP-SEP-051 Rev. 1

This page intentionally left blank. 


\subsection{PRESSURE AND GAS GENERATION EVALUATION}

As indicated in Part B, Section 4.6, there are no trapped gaseous isotopes, and the gas generation rate is considered trivial. Because the paint cans are required to be punctured and there are NucFil filters in both the inner cavity cover and the drum lid, there is no potential for pressurization. 
HNF-SD-TP-SEP-051 Rev. 1

This page intentionally left blank.

B9-2 


\subsection{PACKAGE TIEDOWN SYSTEM EVALUATION}

\subsection{SYSTEM DESIGN}

Up to 30 drums may be positioned in a $2 x$ (up to 15) array oriented axially on the trailer centerline. They shall be oriented on the trailer centerline. The array shall be surrounded by $2 \times 4-$ in. wooden cleats nailed to the deck. In addition, a transverse cleat shall be located between each $2 \times 2$ group within the array and also nailed to the deck. The front pair of drums shall be no closer than $2.74 \mathrm{~m}(9 \mathrm{ft})$ from the normally occupied space of the cab if the drums are of maximum allowable activity. Drums of less-than-maximum allowable activity may be located closer than 2.74 $\mathrm{m}(9 \mathrm{ft})$, but shall not result in a dose rate greater than $0.02 \mathrm{mSv} / \mathrm{h}(2 \mathrm{mrem} / \mathrm{h})$ in the normally occupied space of the cab. See Figure B10-1.

If necessary for load distribution, the load may be divided into two arrays, one forward and one aft, with a space between. They shall be two drums wide oriented on the trailer centerline.

\subsection{ATTACHMENTS AND RATINGS}

The cleat nailing must not be less than that shown in Figure B10-1. Each over-the-top strap must be tightened using standard rigging/security tensioning practices and using straps with minimum tensile load-rated capability of $1,366.7 \mathrm{~kg}(3,013 \mathrm{lb})$. Their working load limit and the trailer attachment points must be compatible with this tension requirement. 
Figure B10-1. Truck Loading Arrangement and Details.

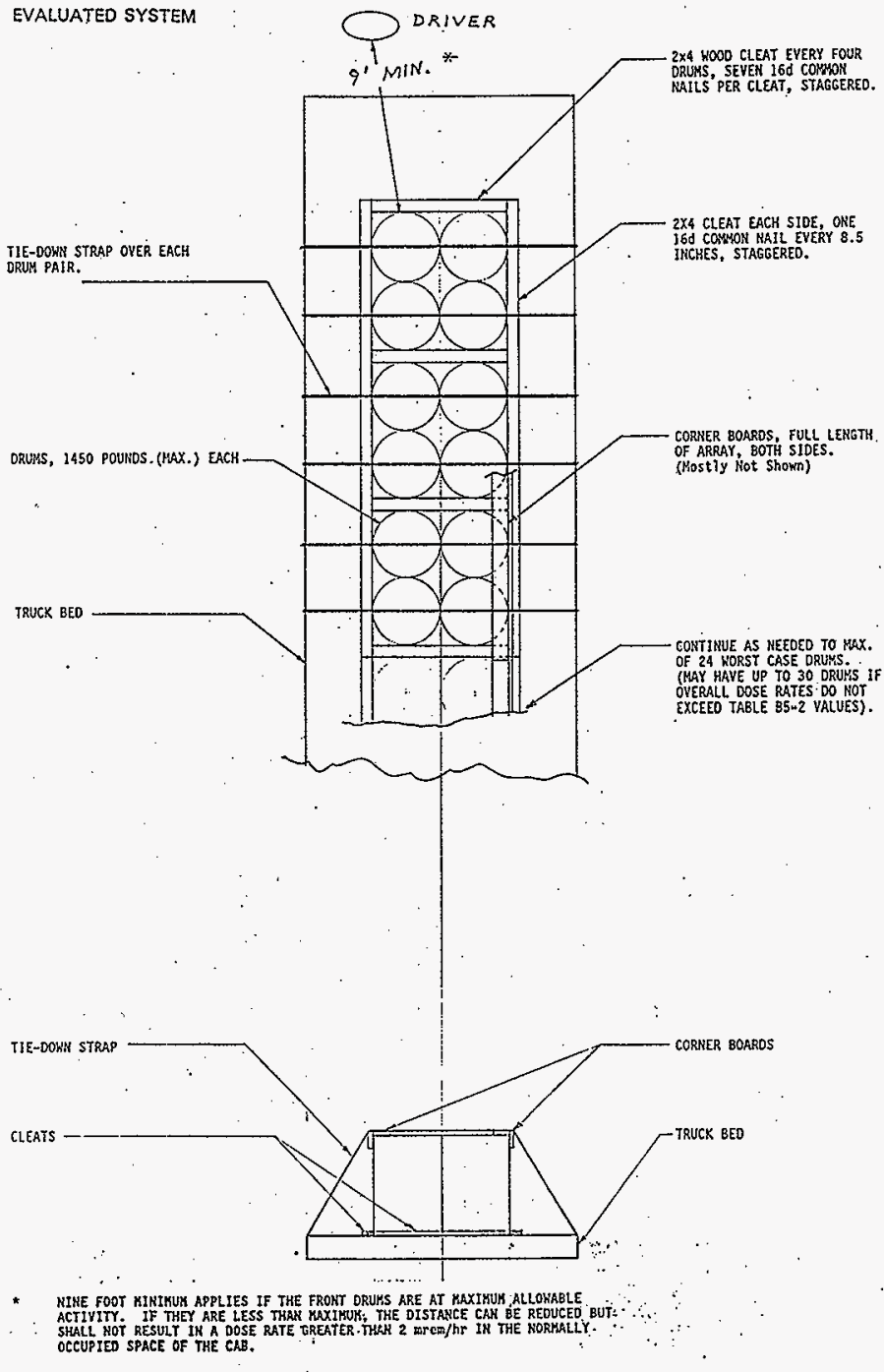




\subsection{APPENDIX: TIEDOWN CALCULATION}

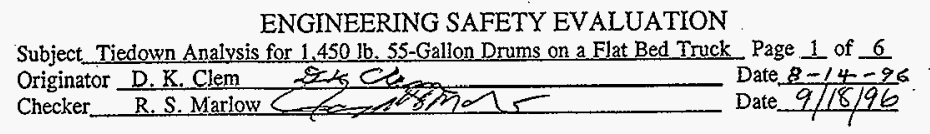

\section{Objective:}

The objective of this analysis is to evaluate the proposed drum arrangement and tiedown method with regard to the applicable requirements of 49 CFR 393.

II. References:

49 CFR 393, 1995, "Federal Motor Carrier Safety Regulations," Code of Federal Regulations, as amended.

Marks, L. S., 1951, Mechanical Engineers Handbook, Fifth Edition, McGraw Hill Book Company, New York, New York.

III. Results and Conclusions:

The analysis shows that the illustrated tiedown system is adequate for imposed loads of $0.62 \mathrm{~g}$. longitudinal and $0.5 \mathrm{~g}$ lateral on drums with a gross weight up to $1,450 \mathrm{lb} / \mathrm{drum}$. No credit is taken for friction, but it is recognized that friction will exist and will provide an additional safety factor. 
ENGINEERING SAFETY EVALUATION

Subject Tiedown Analysis for $1,450 \mathrm{lb}, 55$-Galion Drums on a Flat Bed Truck Page 2 of 6

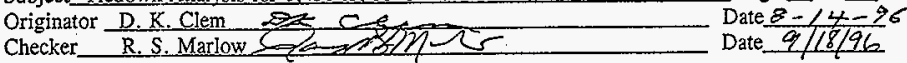

\section{Evaluation:}

Evaluated system:
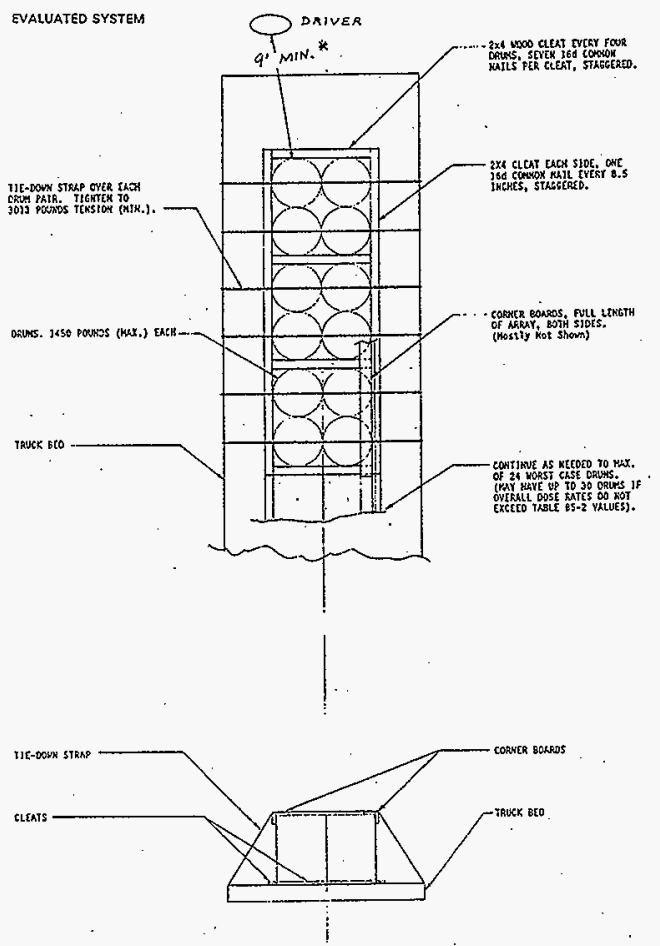

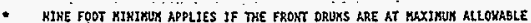

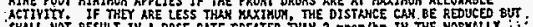

SHRLL NOT RESULT IH A DOSE
OCCUPIED SPACE OF THE CAE. 


\section{ENGINEERING SAFETY EVALUATION}

Subject Tiedown Analysis for 1,450 lb, 55-Gallon Drums on a Flat Bed Truck Page 3 of 6 Originator D. K. Clem _ Date $8-14-96$ Checker

Longitudinal resistance:

Assumptions:

- Resistance provided by cleats alone. No credit for friction.

- Nail strength value taken at ultimate for coastal fir. ( $\sim 540 \mathrm{lb} /$ nail) (Marks 1951).

- Maximum load on a single cleat is four (4) drums at $0.62 \mathrm{~g}$

$=(4)(-1,450)(0.62)=3,596 \mathrm{lb}(49$ CFR 393).

Nails required:

$$
\frac{3,596}{540}=6.7
$$

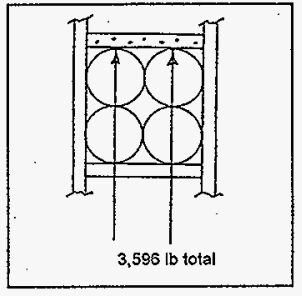

Use seven (7) evenly spaced and staggered.

Lateral resistance:

Assumption:

Same as longitudinal case except maximum load/four (4) drums at $0.5 g=(4)(1,450)(0.5)=$ $2,900 \mathrm{lb}$.

Nails required:

$$
\frac{2,900}{540}=5.37
$$

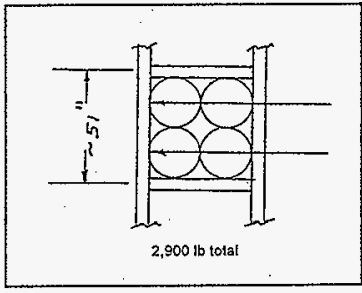

Use six (๑) 51 in. or one every 8.5 in., staggered.

Drum tipping (single drum, longitudinal):

Assumptions:

- Drum slides until it contacts cleats.

$$
\mathrm{M}_{\text {(Tipping) }}=(1,450)(0.62)(17.15)=15,418 \text { in }-1 \mathrm{~b}
$$
(ignore cleat)

$$
\mathrm{M}_{(\text {Rigbting) }}=(1,450)(11.5)=16,675 \mathrm{in}-1 \mathrm{~b}
$$

$$
\mathrm{M}_{\mathrm{R}}>\mathrm{M}_{\mathrm{T}} \therefore \text { Tipping will not occur at } 0.62 \mathrm{~g} \text {. }
$$

Since lateral load of $0.5 \mathrm{~g}$ is $<0.62 \mathrm{~g}$, tipping will not occur in lateral direction either. 
ENGINEERING SAFETY EVALUATION

Subject Tiedown Analysis for 1.450 lb. 55-Gallon Drums on a Flat Bed Truck Page 4 of 6 $\begin{array}{ll}\text { Originator D.K. Clem } & \text { Date } 8-14-96 \\ \text { Checker R.S. Marlow } & \text { Date } q / 18 / 86\end{array}$

Drum tipping (pairs, longitudinal):

Consider the case of two drums, one will slide until it contacts cleat. The other slides until it contacts the rim with the first drum.

Determine tipping situation from that point.

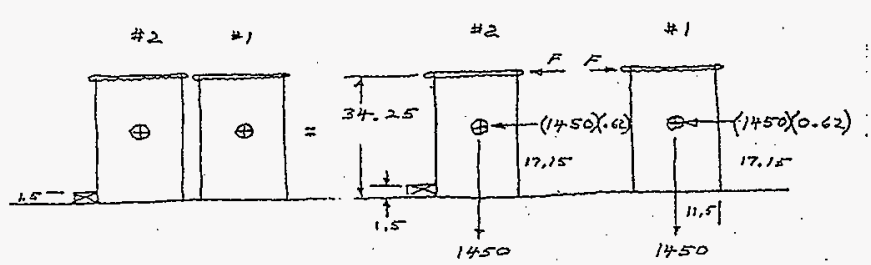

Drum \#1:

$$
\begin{aligned}
& F=(1450)(0.62)=899 \mathrm{lb} \\
& M_{\text {(Tipping) }}=F(34.25-17.15)=15,372 \mathrm{in}-\mathrm{lb} \\
& M_{\left(R_{\text {ighting) }}\right.}=(1450)(11.5)=16,675 \mathrm{in}-\mathrm{lb} \\
& M_{R}>M_{T} \therefore \text { Drum \#1 will not tip. }
\end{aligned}
$$

Drum \#2:

$$
M_{\text {(Tipping) }}=(899)(34.25)+(1,450)(0.62)(17.15)=46,209 \text { in }-1 \mathrm{~b}
$$

(ignore cleat height)

$$
M_{(\text {Rigaciog) }}=(1,450)(11: 5)=16,675 \text { in }-1 b
$$

Net tipping moment: $\quad 46,209-16,675=29,534 \mathrm{in}-1 \mathrm{~b}$

$$
\mathrm{M}_{\mathrm{T}}>>\mathrm{M}_{\mathrm{R}} \quad \therefore \text { Drum } \# 2 \text { will tip. }
$$

When the base of Drum $\# 1$ contacts the base of Drum $\# 2, F=0$ and $M_{T}$ is greatly reduced. However, shifting of the center of gravity due to the angle of the tip results in $M_{T}$ still being slightly greater than $M_{R}$. The drum will fall over without additional restraint (calculation not shown). 
ENGINEERING SAFETY EVALUATION

Subject Tiedown Analysis for $1.450 \mathrm{Hb}$. 55-Gallon Drums on a Flat Bed Truck Page 5 of 6 Originator D.K.Clem
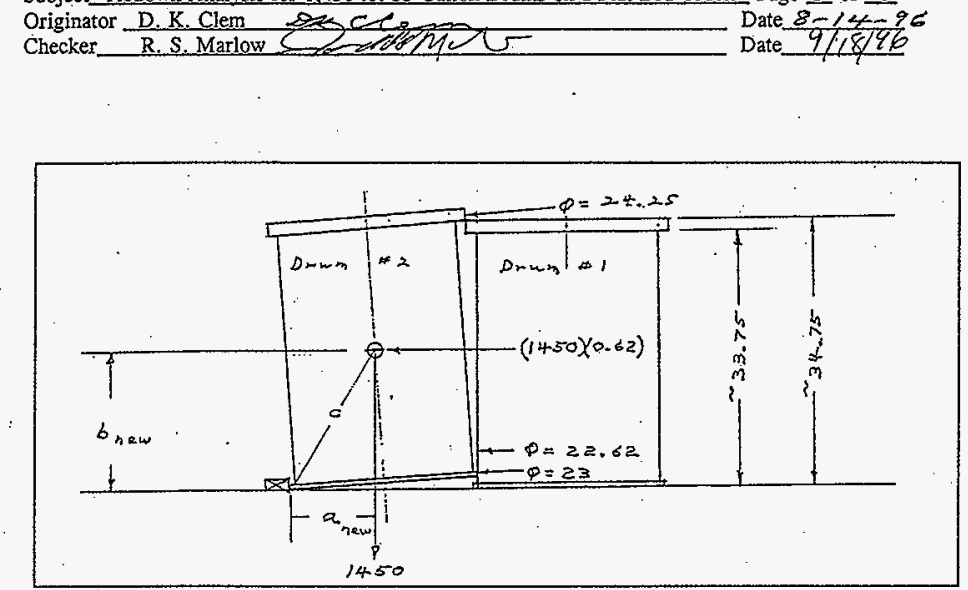

\section{Tiedowns:}

With reference to the previous "pair tipping" case: It is desirable to apply sufficient force through tiedowns to prevent tipping of the leading drum (Drum \#2) due to forces imposed in it by the following drum (Drum \#1). The same tipping scenario is applicable to both lateral loads and longitudinal loads, but the loads and the action of the tiedowns is different for the two directions.

General assumptions:

- Consider the case for tipping due to longitudinal loadings (loads of $0.62 \mathrm{~g}$ ) as bounding both lateral and longitudinal loading conditions. Prescribed lateral loading is $0.5 \mathrm{~g}$, so use of $0.62 \mathrm{~g}$ is conservative.

- From the "pair tipping" case: A net righting moment of 29,534 in-lb is required to be considered by the tiedown.

- No credit is taken for friction. Drums are assumed to slide to the cleats or to the adjacent drum.

- One lateral strap crosses over the top centerline of each lateral pair of drums.

- Truck bed width is assumed to be within the range of 88 in. to 96 in. A significantly wide bed, such as a lowboy, would require increased strap tension.

Tiedowns for longitudinal loading:

- Tiedown tension is translated to its vertical component at drum centerline. The horizontal component does not contribute to the longitudinal tipping case. 
ENGINEERING SAFETY EVALUATION

Subject Tiedown Analysis for $1.450 \mathrm{tb}$. 55-Gallon Drums on a Flat Bed Truck Page 6 of 6
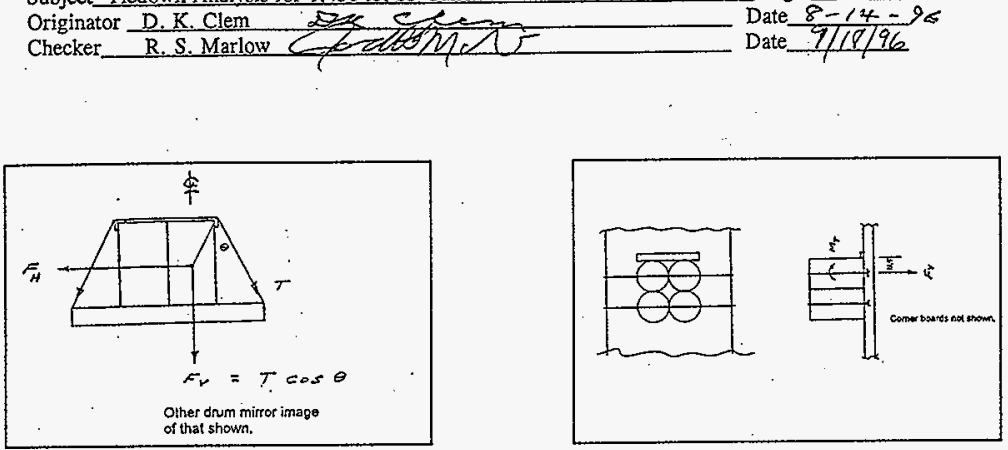

Required that $\mathrm{F}_{\mathrm{v}}(11.5)=\mathrm{M}_{\mathrm{T}}$

$$
F_{v}=\frac{29,534}{11.5}=2,568 \mathrm{lb}
$$

Check tension required for bed widths of 88 in. to 96 in. ( $\left(\theta^{\prime} s\right.$ of $26.72^{\circ}$ to $\left.31.54^{\circ}\right)$

$$
\mathrm{T}_{\text {required }}=\frac{\mathrm{F}_{\mathrm{Y}}}{\cos \theta}=\frac{2,568}{\cos 31.54}=3,013 \mathrm{Ib}
$$

for 96 in. width. This is worst case within range.

This is also the worst case between the lateral versus longitudinal loading conditions.

Therefore, tiedown tension of $3,013 \mathrm{lb}$ or greater will prevent drum tipping in lateral or longitudinal direction up to $0.62 \mathrm{~g}$.

Operational constraints:

1. Truck shall have a wood deck.

2. Truck bed with shall be in range of $88 \mathrm{in}$. to $96 \mathrm{in}$. Tiedown tension must be increased for width exceeding 96 in.

3. One tiedown strap per lateral drum pair, tightened to $3,013 \mathrm{lb}$ minimum.

4. Drum array shall be two drums wide, centered on the truck centerline. Maximum number of drums shall be limited by truck capacity or 30 drums, whichever is less.

5. Wooden cleats and nailing shall be as shown.

6. One or more arrays may be positioned along the lenigth of the truck, if needed, to balance axle loading. 


\begin{tabular}{|c|c|c|c|c|c|}
\hline \multicolumn{6}{|c|}{ DISTRIBUTION SHEET } \\
\hline \multirow{2}{*}{$\begin{array}{l}\text { To } \\
\text { Distribution }\end{array}$} & \multirow{2}{*}{\multicolumn{3}{|c|}{$\begin{array}{l}\text { From } \\
\text { Packaging Engineering }\end{array}$}} & \multicolumn{2}{|l|}{ Page 1 of 1} \\
\hline & & & & \multicolumn{2}{|c|}{ Date Mar. 25, 1998} \\
\hline \multicolumn{4}{|c|}{ Project Title/Work Order } & \multicolumn{2}{|c|}{ EDT No. } \\
\hline \multicolumn{4}{|c|}{$\begin{array}{l}\text { Safety Evaluation for Packaging (Onsite) for the Concrete- } \\
\text { Shielded RH TRU Drum for the } 327 \text { Postirradiation Testing } \\
\text { Laboratory (HNF-SD-TP-SEP-051) }\end{array}$} & \multicolumn{2}{|c|}{ ECN No. 640863} \\
\hline Name & MSIN & $\begin{array}{l}\text { Text } \\
\text { With All } \\
\text { Attach. }\end{array}$ & Text Only & $\begin{array}{l}\text { Attach./ } \\
\text { Appendix } \\
\text { Only }\end{array}$ & $\begin{array}{c}\text { EDT/ECN } \\
\text { Only }\end{array}$ \\
\hline $\begin{array}{l}\text { R. D. Brown } \\
\text { P. C. Ferrell } \\
\text { J. G. Field } \\
\text { J. F. Henderson } \\
\text { T. Romano } \\
\text { R. J. Smith } \\
\text { Central Files } \\
\text { HNF-SD-TP-SEP-051 File }\end{array}$ & $\begin{array}{l}L 1-03 \\
H I-15 \\
H 1-15 \\
L 1-03 \\
H 1-15 \\
H 1-15 \\
-B 1-07 \\
H 1-15\end{array}$ & $\begin{array}{l}X \\
X \\
X \\
X \\
\end{array}$ & & - & $\begin{array}{l}X \\
X \\
X\end{array}$ \\
\hline
\end{tabular}

